\title{
Water-Quality Conditions of Inflow, Outflow, and Impounded Water at Rathbun Reservoir, lowa, Clinton and Pomona Lakes, Kansas, and Harlan County Reservoir, Nebraska, May Through August 1993
}

By ANDREW C. ZIEGLER, PATRICK P. RASMUSSEN, MICHAEL D. CARLSON, and DIRK A. HARGADINE

U.S. GEOLOGICAL SURVEY

Open-File Report 95-472

Prepared in cooperation with the

U.S. ARMY CORPS OF ENGINEERS

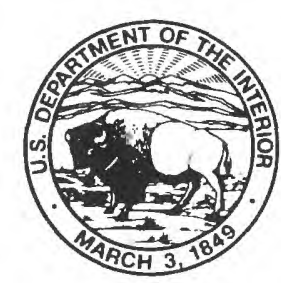

Lawrence, Kansas

1995 


\section{U.S. DEPARTMENT OF THE INTERIOR \\ BRUCE BABBITT, Secretary}

U.S. GEOLOGICAL SURVEY

Gordon P. Eaton, Director

For additional information write to:

District Chief

U.S. Geological Survey

Water Resources Division

4821 Quail Crest Place

Lawrence, Kansas 66049-3839
Copies of this report can be purchased from:

U.S. Geological Survey

Earth Science Information Center

Open-File Reports Section

Box 25286, MS 517

Denver Federal Center

Denver, CO 80225 


\section{CONTENTS}

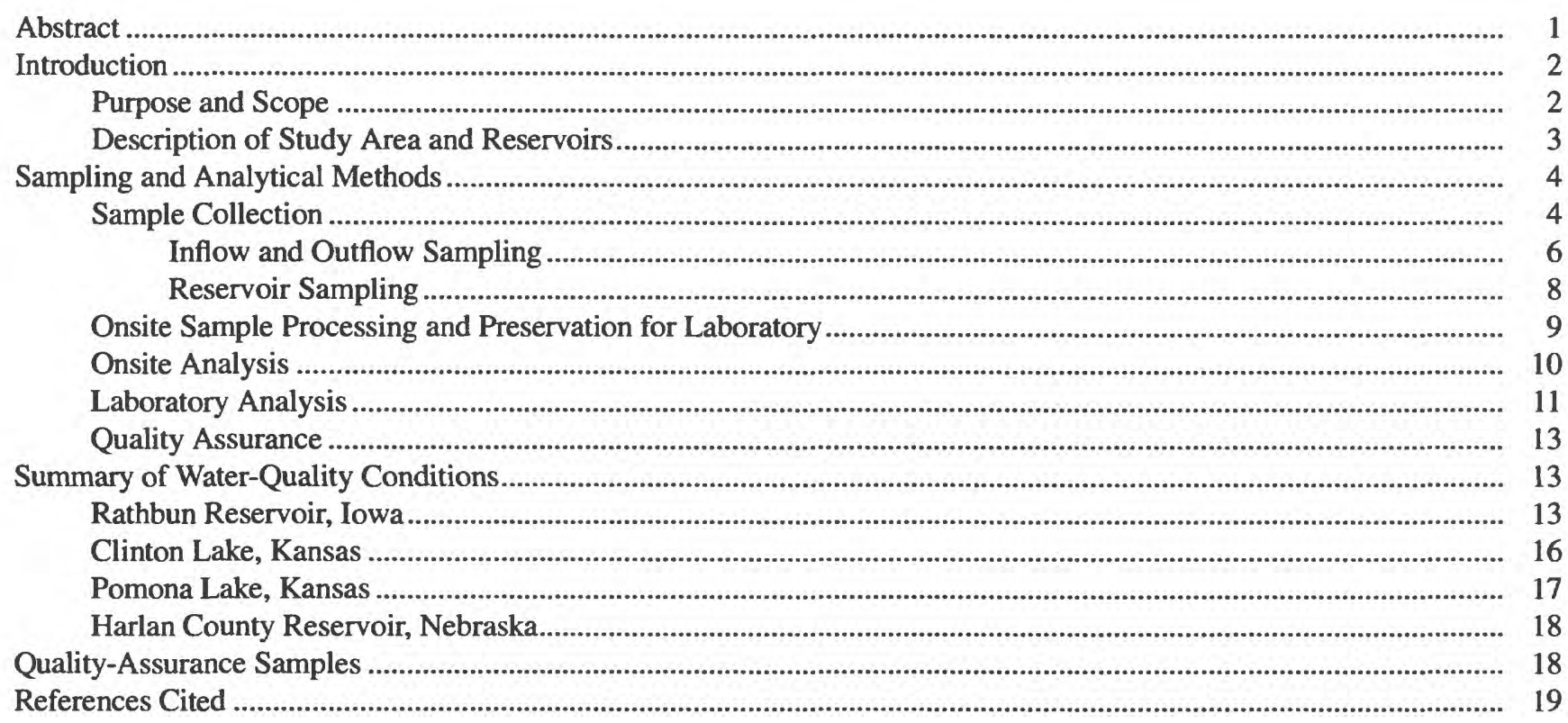

\section{FIGURES}

1-5. Map showing:

1. Location of Rathbun Reservoir, Iowa, Clinton and Pomona Lakes, Kansas, and Harlan County Reservoir, Nebraska

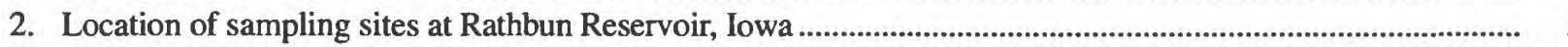

3. Location of sampling sites at Clinton Lake, Kansas ............................................................................

4. Location of sampling sites at Pomona Lake, Kansas ............................................................................ 7

5. Location of sampling sites at Harlan County Reservoir, Nebraska ............................................................... 8

6. Graphs showing vertical profiles of specific conductance, $\mathrm{pH}$, water temperature, and dissolved oxygen at sampling sites RA-3 in Rathbun Reservoir, Iowa, CL-2 in Clinton Lake, Kansas, PO-3 in Pomona Lake, Kansas, and $\mathrm{HC}-2$ in Harlan County Reservoir, Nebraska.

\section{TABLES}

1. Mean monthly precipitation at Centerville, Iowa, Lawrence and Lyndon, Kansas, and Naponee, Nebraska, for 1951-80 and monthly precipitation totals for 1993 at Rathbun Reservoir, lowa, Clinton and Pomona Lakes, Kansas, and Harlan County Reservoir, Nebraska.

2. Physical characteristics of Rathbun Reservoir, Iowa, Clinton and Pomona Lakes, Kansas, and Harlan County Reservoir, Nebraska

3. Sampling sites at Rathbun Reservoir, Iowa, Clinton and Pomona Lakes, Kansas, and Harlan County Reservoir, Nebraska.

4. Reservoir elevations and water-quality data for water samples collected from Rathbun Reservoir, Iowa, June and August 1993.

5. Reservoir elevations and water-quality data for water samples collected from Clinton Lake, Kansas, May and July 1993

(1)




\section{TABLES-Continued}

6. Reservoir elevations and water-quality data for water samples collected from Pomona Lake, Kansas, June and July 1993

7. Reservoir elevations and water-quality data for water samples collected from Harlan County Reservoir, Nebraska, June and July 1993

8. Vertical specific-conductance, $\mathrm{pH}$, water-temperature, and dissolved-oxygen profiles for Rathbun Reservoir, Iowa, June and August 1993

9. Vertical specific-conductance, $\mathrm{pH}$, water-temperature, and dissolved-oxygen profiles for Clinton Lake, Kansas, May and July 1993

10. Vertical specific-conductance, $\mathrm{pH}$, water-temperature, and dissolved-oxygen profiles for Pomona Lake, Kansas, June and July 1993

11. Vertical specific-conductance, $\mathrm{pH}$, water-temperature, and dissolved-oxygen profiles for Harlan County Reservoir, Nebraska, June and July 1993

CONVERSION FACTORS, ABBREVIATIONS, AND VERTICAL DATUM

\begin{tabular}{rcl}
\hline Multiply & By & To obtain \\
\hline inch (in.) & 25.4 & millimeter \\
foot (ft) & 0.3048 & meter \\
mile (mi) & 1.609 & kilometer \\
acre & 4,047 & square meter \\
acre & 0.4047 & square hectometer \\
acre-foot (acre-ft) & 1,233 & cubic meter \\
cubic foot per second ( $\left.\mathrm{ft}^{3} / \mathrm{s}\right)$ & 0.02832 & cubic meter per second \\
quart $(\mathrm{qt})$ & 0.9464 & liter \\
degree Fahrenheit $\left({ }^{\circ} \mathrm{F}\right)$ & $\left({ }^{1}\right)$ & degree Celsius $\left({ }^{\circ} \mathrm{C}\right)$ \\
\hline
\end{tabular}

${ }^{10} \mathrm{C}=\left({ }^{\circ} \mathrm{F}-32\right) / 1.8$.

Sea level: In this report, "sea level" refers to the National Geodetic Vertical Datum of 1929-a geodetic datum derived from a general adjustment of the first-order level nets of both the United States and Canada, formerly called Sea Level Datum of 1929. 


\title{
Water-Quality Conditions of Inflow, Outflow, and Impounded Water at Rathbun Reservoir, lowa, Clinton and Pomona Lakes, Kansas, and Harlan County Reservoir, Nebraska, May Through August 1993
}

\author{
By Andrew C. Ziegler, Patrick P. Rasmussen, Michael D. Carlson, and Dirk A. Hargadine
}

\begin{abstract}
During May through August 1993, waterquality samples were collected twice from selected sites in Rathbun Reservoir, Iowa, Clinton and Pomona Lakes, Kansas, and Harlan County Reservoir, Nebraska. Water samples were analyzed for specific conductance, $\mathrm{pH}$, water temperature, turbidity, transparency, dissolved oxygen, chemical oxygen demand, fecal coliform bacteria, major ions, total suspended solids, nutrients (selected nitrogen and phosphorous species), alkalinity, selected trace metals, total organic carbon, selected herbicides, and chlorophyll $-a$ and $-b$. These data are presented in this report.
\end{abstract}

Most concentrations of turbidity, chemical oxygen demand, major ions, total suspended solids, nutrients, alkalinity, selected trace metals, total organic carbon, and chlorophyll were largest from water samples collected in June from Rathbun Reservoir, Pomona Lake, and Harlan County Reservoir. Most concentrations of these constituents were largest in July in water samples collected from Clinton Lake.

Concentrations of fecal coliform bacteria in water samples collected in the reservoirs near swimming beaches ranged from less than 1 to 730 colonies per 100 milliliters of water. Concentrations were largest in samples from Harlan County Reservoir, and some of the concentrations exceeded the U.S. Environmental Protection
Agency's full-body contact criteria of 200 colonies per 100 milliliters of water.

During May through August 1993, precipitation at all four reservoirs exceeded mean precipitation at nearby long-term precipitation gages; precipitation ranged from 7.76 inches above the long-term mean at Pomona Lake to 12.62 inches above the long-term mean at Rathbun Reservoir. Reservoir water-surface elevations exceeded flood-pool elevation at Rathbun Reservoir in August. The reservoir water-surface elevations exceeded the multipurpose-pool elevation by 4 feet in Clinton Lake, by 19 feet in Pomona Lake, and by 2 feet in Harlan County Reservoir in July.

Vertical profiles of specific conductance, $\mathrm{pH}$, water temperature, and dissolved oxygen are presented for selected sites in the reservoirs. Thermal stratification of the water occurred at one site in Rathbun Reservoir in August, at two sites in Clinton Lake in May, at one site in Pomona Lake in June, and at one site in Harlan County Reservoir in June.

Total triazine herbicide concentrations in water samples from all four reservoirs ranged from 0.2 to 19 micrograms per liter and were largest in water samples from Rathbun Reservoir in June. Concentrations of atrazine exceeded the U.S. Environmental Protection Agency's Maximum Contaminant Level of 3.0 micrograms per liter for drinking water in at least one sample each from Rathbun Reservoir, Clinton Lake, and Pomona Lake. Concentrations of cyanazine exceeded the 
U.S. Environmental Protection Agency's Health Advisory Level of 1.0 microgram per liter for drinking water in water samples from Rathbun Reservoir. The outflow from Rathbun Reservoir had an atrazine concentration of 2.9 micrograms per liter in August and exceeded the U.S. Environmental Protection Agency's Health Advisory Level for cyanazine.

\section{INTRODUCTION}

Increased concentrations of suspended solids, nutrients, certain trace metals, herbicides, and chlorophyll- $a$ and $-b$ can degrade reservoir water quality. The U.S. Army Corps of Engineers, Kansas City District, manages Rathbun Reservoir in Iowa, Clinton and Pomona Lakes in Kansas, and Harlan County Reservoir in Nebraska (fig. 1). These four reservoirs are used for flood control, water supply, and recreational activities. Degradation of water quality in these reservoirs can: (1) cause water to be unsuitable for irrigation, (2) pose potential public-health problems in treated drinking water, (3) inhibit growth, reproduc- tion, and diversity of aquatic organisms, and (4) reduce the recreational use of the reservoirs.

The continued monitoring of these reservoirs can more accurately define water quality. Results of this study, conducted by the U.S. Geological Survey (USGS), will help define water-quality conditions in these reservoirs and will aid the U.S. Army Corps of Engineers in managing the water resources for maximum beneficial use. This study was funded by the Kansas City District, U.S. Army Corps of Engineers, under an interagency agreement.

\section{Purpose and Scope}

The purpose of this report is to describe temporal variations and stratification patterns of specific conductance, $\mathrm{pH}$, water temperature, turbidity, transparency, dissolved oxygen, selected chemical constituents, fecal coliform bacteria, selected herbicides, and chlorophyll- $a$ and $-b$ in reservoirs used for public supply. This report presents the water-quality data collected from four Midwestern reservoirs during May through August 1993.

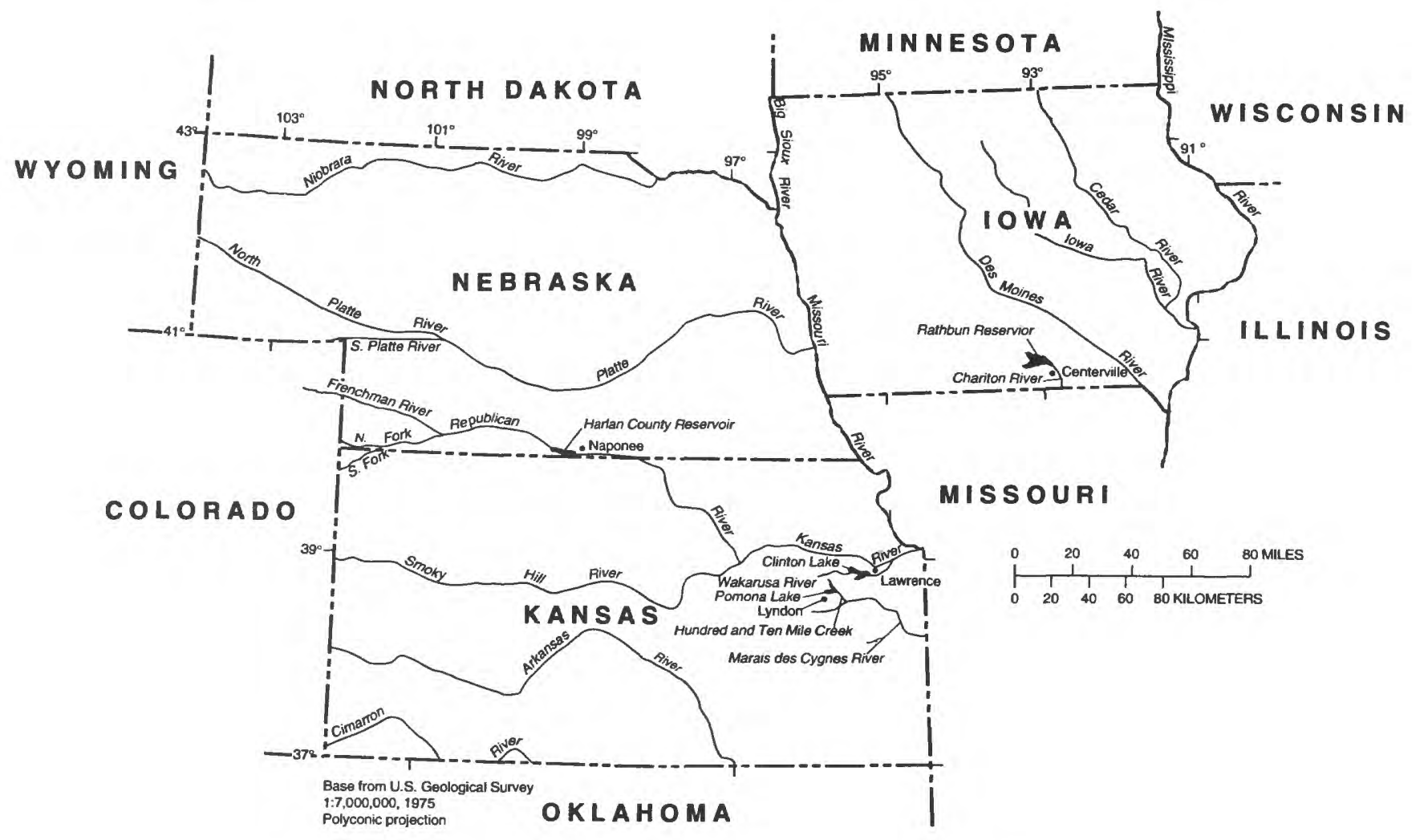

Figure 1. Location of Rathbun Reservoir, lowa, Clinton and Pomona Lakes, Kansas, and Harlan County Reservoir, Nebraska. 
Description of Study Area and Reservoirs

The general physiography, topography, land use, and precipitation for the four reservoirs are summarized in the following paragraphs. Mean monthly precipitation as determined at nearby National Weather Service gages for 1951-80 (National Oceanic and Atmospheric Administration, 1951-80), and monthly precipitation totals measured for 4 months prior to and during the study at U.S. Army Corps of Engineer Project offices at each reservoir are summarized in table 1. Physical characteristics of the reservoirs are presented in table 2.

Rathbun Reservoir is located on the Chariton River in south-central Iowa in the Southern Iowa Drift Plain physiographic province (Prior, 1991). Topography consists of gently rolling hills. Land use is mostly cropland with some grazing land (Anderson, 1967). Mean annual precipitation is about 34 in. in the Rathbun Reservoir drainage basin (U.S. Geological Survey, 1986, p. 231).
Clinton and Pomona Lakes are located in eastcentral Kansas in the Central Lowland physiographic province (Fenneman, 1946). Topography consists of gently rolling hills. Land use is cropland with some grazing land (Anderson, 1967). Mean annual precipitation is about 35 in. in the Clinton Lake and Pomona Lake drainage basins (U.S. Geological Survey, 1986, p. 237).

Harlan County Reservoir is located in southcentral Nebraska in the Great Plains physiographic province (Fenneman, 1946). Topography consists of gently rolling hills. The reservoir receives inflow from Colorado, Kansas, and Nebraska. Land use is mostly cropland, with grazing land in the eastern part of the drainage basin and subhumid grassland and semiarid grazing land in the western part of the basin (Anderson, 1967). Mean annual precipitation in the drainage basin ranges from 12 to 24 in. (U.S. Geological Survey, 1986, p. 169, 317).

Table 1. Mean monthly precipitation at Centerville, lowa, Lawrence and Lyndon, Kansas, and Naponee, Nebraska, for 1951-80 and monthly precipitation totals for 1993 at Rathbun Reservoir, lowa, Clinton and Pomona Lakes, Kansas, and Harlan County Reservoir, Nebraska

[Precipitation given in inches, data for 1951-80 from National Oceanic and Atmospheric Administration (1951-80). --, no data]

\begin{tabular}{ccccccccccc}
\hline $\begin{array}{c}\text { Site no. } \\
\text { (figs. 2-5) }\end{array}$ & Site name & Jan. & Feb. & Mar. & Apr. & May & June & July & Aug. & Total \\
\hline 1 & $\begin{array}{c}\text { Centerville, Iowa } \\
(1951-80)\end{array}$ & 1.13 & 0.95 & 2.52 & 3.66 & 3.56 & 4.13 & 3.80 & 4.30 & $\mathbf{2 4 . 0 5}$ \\
2 & $\begin{array}{c}\text { Rathbun Reservoir, Iowa } \\
\quad(1993)\end{array}$ & 1.18 & .92 & 2.60 & 3.67 & 5.70 & 4.24 & 14.28 & 4.19 & $\mathbf{3 6 . 7 8}$ \\
3 & $\begin{array}{c}\text { Lawrence, Kansas } \\
\quad(1951-80)\end{array}$ & 1.11 & 1.25 & 2.50 & 3.27 & 4.22 & 5.49 & 4.45 & 3.94 & $\mathbf{2 6 . 2 3}$ \\
4 & $\begin{array}{c}\text { Clinton Lake, Kansas } \\
\quad(1993)\end{array}$ & 1.96 & 1.30 & 2.58 & 6.94 & 6.73 & 5.40 & 14.82 & 1.45 & $\mathbf{4 1 . 1 8}$ \\
5 & $\begin{array}{c}\text { Lyndon, Kansas } \\
(1951-80)\end{array}$ & .84 & 1.00 & 2.41 & 2.98 & 4.47 & 5.29 & 4.05 & 4.03 & $\mathbf{2 5 . 0 7}$ \\
7 & $\begin{array}{c}\text { Pomona Lake, Kansas } \\
\quad(1993)\end{array}$ & 1.86 & 2.10 & 2.39 & 5.25 & 8.34 & 5.01 & 10.56 & 1.69 & $\mathbf{3 7 . 0 2}$ \\
8 & $\begin{array}{c}\text { Naponee, Nebraska } \\
\text { (1951-80) }\end{array}$ & .55 & .74 & 1.51 & 1.96 & 3.37 & 4.13 & 3.26 & 3.16 & $\mathbf{1 8 . 6 8}$ \\
\hline $\begin{array}{c}\text { Harlan County Reservoir, } \\
\text { Nebraska (1993) }\end{array}$ & 1.11 & 1.30 & 1.91 & 2.05 & 2.57 & 3.62 & 13.71 & 6.37 & $\mathbf{3 2 . 6 4}$ \\
\hline
\end{tabular}

\footnotetext{
${ }^{1}$ Site 1-Average precipitation at Centerville, Iowa (National Oceanic and Atmospheric Administration, 1951-80).

Site 2-Precipitation during 1993 at Rathbun Reservoir, lowa.

Site 3-Average precipitation at Lawrence, Kansas (National Oceanic and Atmospheric Administration, 1951-80).

Site 4-Precipitation during 1993 at Clinton Lake, Kansas.

Site 5-Average precipitation at Lyndon, Kansas (National Oceanic and Atmospheric Administration, 1951-80).

Site 6-Precipitation during 1993 at Pomona Lake, Kansas.

Site 7-Average precipitation at Naponee, Nebraska (National Oceanic and Atmospheric Administration, 1951-80).

Site 8-Precipitation during 1993 at Harlan County Reservoir, Nebraska.
} 
Table 2. Physical characteristics of Rathbun Reservoir, lowa, Clinton and Pomona Lakes, Kansas, and Harlan County Reservoir, Nebraska

[Based on the most recent hydrographic surveys (Garland Kersh, U.S. Army Corps of Engineers, written commun., 1993)]

\begin{tabular}{ccccc}
\hline $\begin{array}{c}\text { Physical } \\
\text { characteristic }\end{array}$ & $\begin{array}{c}\text { Rathbun } \\
\text { Reservoir, } \\
\text { lowa }\end{array}$ & $\begin{array}{c}\text { Clinton Lake, } \\
\text { Kansas }\end{array}$ & $\begin{array}{c}\text { Pomona Lake, } \\
\text { Kansas }\end{array}$ & $\begin{array}{c}\text { Harlan County } \\
\text { Reservoir, } \\
\text { Nebraska }\end{array}$ \\
\hline $\begin{array}{c}\text { Flood-control water- } \\
\text { surface elevation } \\
\text { (feet above sea level) }\end{array}$ & 926.0 & 903.4 & $1,003.0$ & $1,973.5$ \\
$\begin{array}{c}\text { Multipurpose-pool water- } \\
\text { surface elevation } \\
\text { (feet above sea level) }\end{array}$ & 904.0 & 875.5 & 974.0 & $1,946.0$ \\
$\begin{array}{c}\text { Flood-storage capacity } \\
\text { (thousands of acre-feet) }\end{array}$ & 345.8 & 268.4 & 176.0 & 469.7 \\
$\begin{array}{c}\text { Multipurpose-pool } \\
\text { current capacity } \\
\text { (thousands of acre-feet) }\end{array}$ & 199.8 & 129.2 & 64.4 & 315.1 \\
$\begin{array}{c}\text { Inactive current capacity } \\
\text { (thousands of acre-feet) }\end{array}$ & 16.1 & 28.5 & 21.2 & 143.4 \\
$\begin{array}{c}\text { Total flood-control capacity } \\
\text { (thousands of acre-feet) }\end{array}$ & 545.6 & 397.6 & 240.4 & 784.8 \\
$\begin{array}{c}\text { Flood-control-pool } \\
\text { surface area } \\
\text { (acres) }\end{array}$ & 21,000 & 12,891 & 8,522 & 22,820 \\
$\begin{array}{l}\text { Multipurpose-pool } \\
\text { surface area } \\
\text { (acres) }\end{array}$ & 11,000 & 7,006 & 3,871 & 13,262 \\
$\begin{array}{c}\text { Multipurpose-pool } \\
\text { shoreline } \\
\text { (miles) }\end{array}$ & 155 & 85 & 52 & 75 \\
\hline
\end{tabular}

\section{SAMPLING AND ANALYTICAL METHODS}

Sample collection, preservation, and onsite analyses were performed using USGS methods described by Ward and Harr (1990) and Wells and others (1990). Methods for inorganic, organic, and biological analyses are described in detail in Fishman and Friedman (1989), Wershaw and others (1987), and Britton and Greeson (1989), respectively. Methods for the analysis of triazine herbicides by enzyme-linked immunosorbent assay (ELISA) and gas chromatography/mass spectrometry (GC/MS) are described by Pomes and Thurman (1991) and Thurman and others (1990), respectively.

\section{Sample Collection}

Water-quality samples were collected in May or June 1993 and in July or August 1993. Samples were collected at seven to nine sites in each reservoir and at sites on the major inflow and outflow streams of each reservoir (figs. 2-5 and table 3). The sampling sites are long-term monitoring sites used by the U.S. Army Corps of Engineers. At inflow and outflow sites, samples were collected with a depth-integrating sampler or manually (dip sample) at the center of flow. Reservoir samples were collected at $0.1 \mathrm{~m}$ (meter) $(0.33 \mathrm{ft})$ below the reservoir surface and at $1.0 \mathrm{~m}(3.3 \mathrm{ft})$ above the reservoir bottom. Inflow, outflow, and reservoir samples were analyzed for specific conductance, $\mathrm{pH}$, water temperature, turbidity, transparency (secchi and 1-percent light-penetration depth), dissolved oxygen (DO), chemical oxygen demand (COD), fecal coliform bacteria, major ions, total suspended solids (TSS), nutrients (selected nitrogen and phosphorous species), alkalinity, selected trace metals, total organic carbon (TOC), selected herbicides, and chlorophyll- $a$ and $-b$. At the sites specified for fecal coliform only (table 3), samples were collected from less than $0.2 \mathrm{~m}$ 


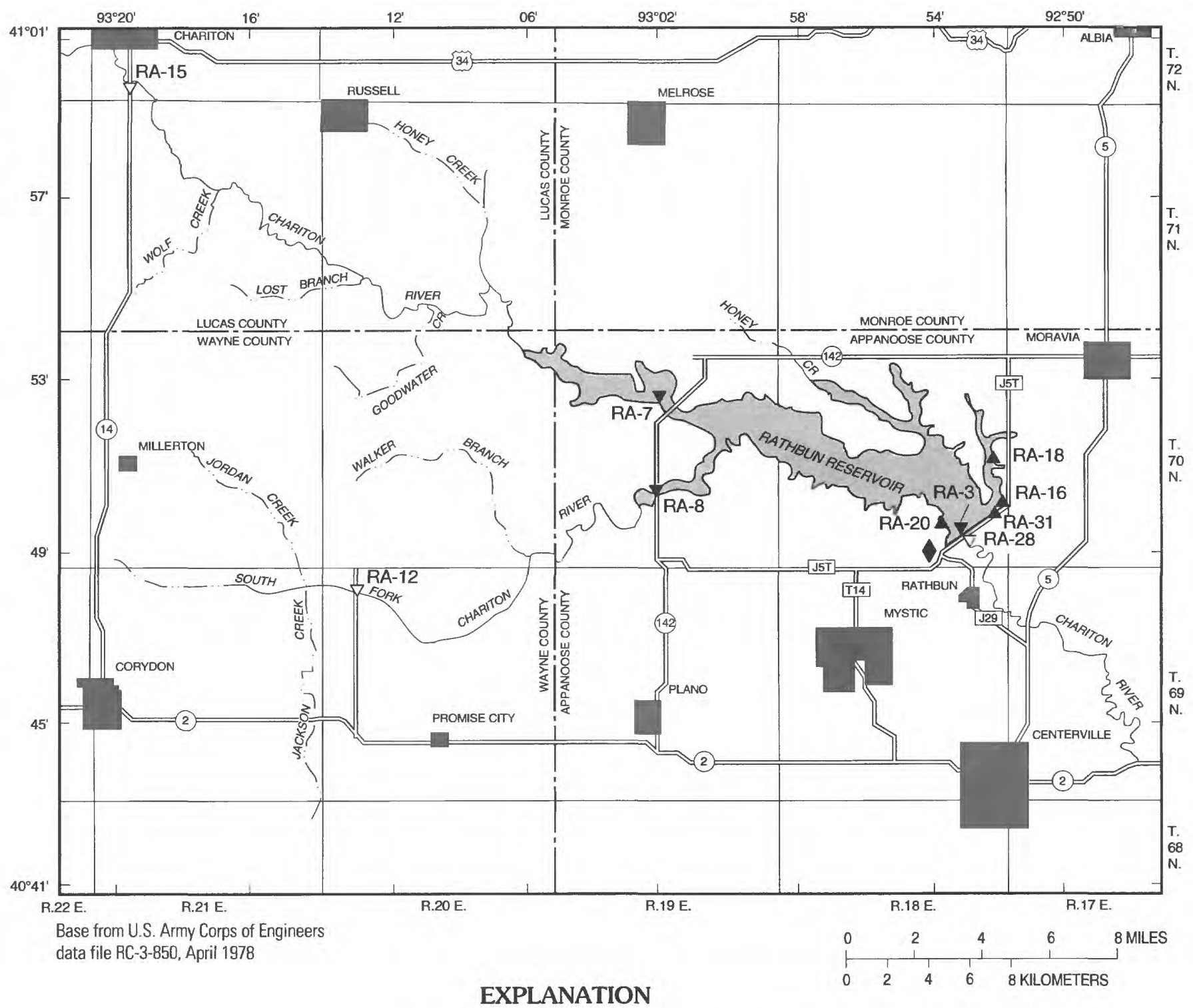

\footnotetext{
Sampling sites-Numbers correspond to map reference numbers used in tables 4 and 8$$
\mathrm{RA}^{-12} \nabla \text { Stream }
$$$$
\mathrm{RA}-8 \nabla \text { Lake }
$$

RA-20 A Fecal coliform only

- Precipitation gage
}

Figure 2. Location of sampling sites at Rathbun Reservoir, lowa (reservoir shown at multipurpose-pool elevation).

$(0.66 \mathrm{ft})$ below the water surface. Measurements of specific conductance, $\mathrm{pH}$, water temperature, light penetration, barometric pressure, and DO were made at the time of sampling. These properties and constituents were measured vertically from $0.1 \mathrm{~m}(0.33 \mathrm{ft})$ below the surface to a depth of $1.0 \mathrm{~m}(3.3 \mathrm{ft})$ above the bottom of the lake at 1- to 2-m (3.3-6.6 ft) intervals. Chlorophyll- $a$ and $-b$ samples were collected with a depth-integrating sampler from the photic zone (maximum depth equal to 1-percent light penetration).

Before each sampling, all equipment was cleaned with a nonphosphate detergent in warm water, rinsed with tap water, soaked in 5-percent hydrochloric acid solution for 30 minutes, rinsed with deionized water, and placed in new plastic bags. Personnel wore powderless polyvinyl chloride (PVC) or latex gloves during the collection of the samples. 


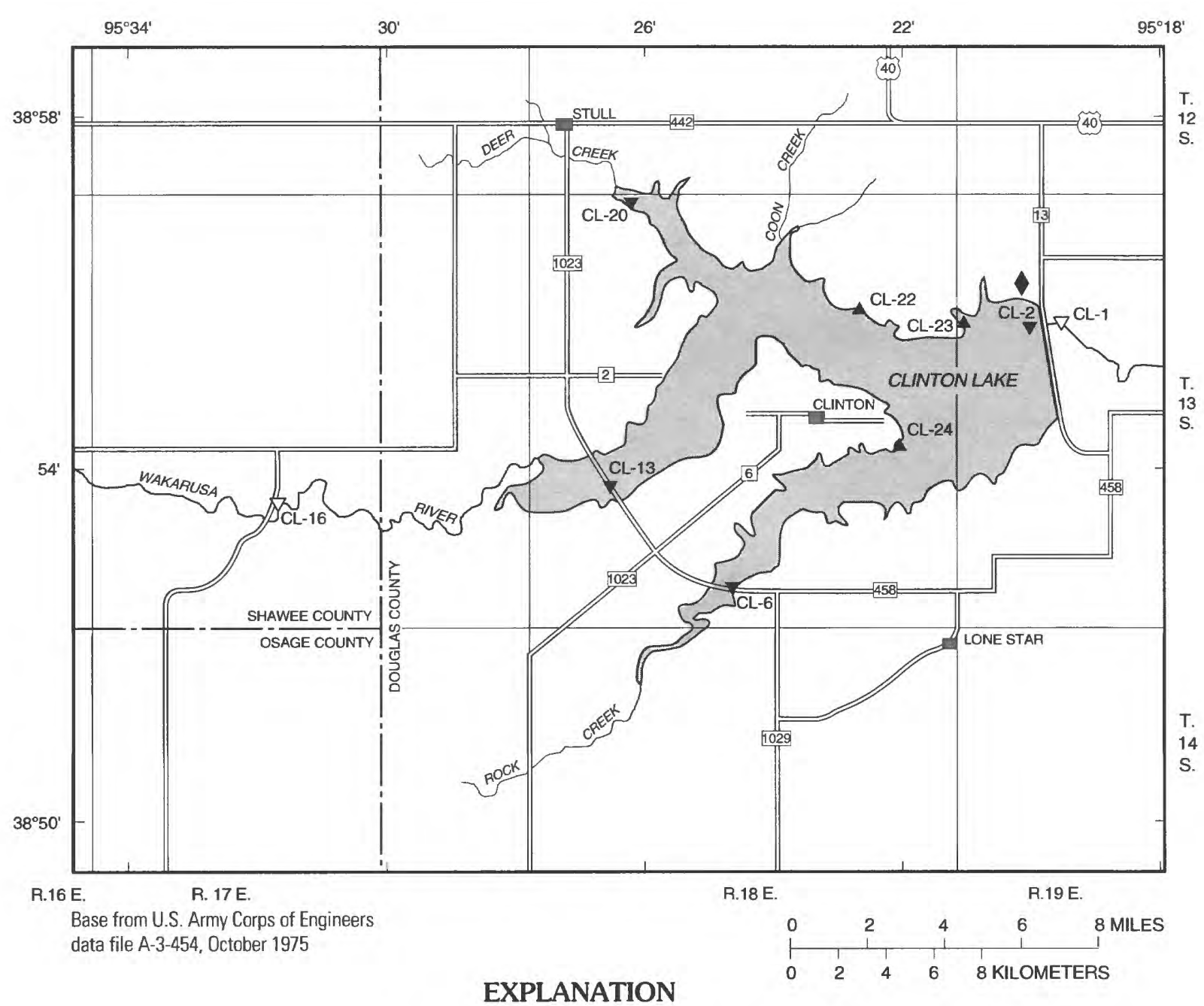

$\begin{array}{cl}\begin{array}{l}\text { Sampling sites - Numbers correspond to map } \\ \text { reference numbers used in tables } 5 \text { and } 9 \\ \mathrm{CL}-16 \nabla\end{array} & \text { Stream } \\ \mathrm{CL}-13 \nabla & \text { Lake } \\ \mathrm{CL}-24 & \text { Fecal coliform only } \\ & \text { Precipitation gage }\end{array}$

Figure 3. Location of sampling sites at Clinton Lake, Kansas (reservoir shown at multipurpose-pool elevation).

\section{Inflow and Outflow Sampling}

Water-quality samples were obtained using USGS sampling techniques (Ward and Harr, 1990; Wells and others, 1990). Specific conductance, $\mathrm{pH}$, water temperature, and DO were measured on water samples at inflow and outflow sampling sites near the point of sample collection with a multiparameter probe. A depth-integrating sampler was submerged at the estimated center of the streamflow to collect a composite sample. Water from the sampler was emptied into a clean polyethylene churn splitter. This process was repeated until the churn splitter was nearly full [ 7 or $13 \mathrm{~L}$ (liters)]. The sample in the churn splitter was mixed, and representative subsamples were collected from the splitter.

During periods of low flow, a dip sample was collected by submerging a churn splitter or a clean 1-L jar into the center of flow with the opening facing toward the current. Using the $1-\mathrm{L}$ jar, the process was repeated until the churn was filled.

Samples for alkalinity analysis were collected in a $500-\mathrm{mL}$ (milliliters) bottle by submerging the bottle 


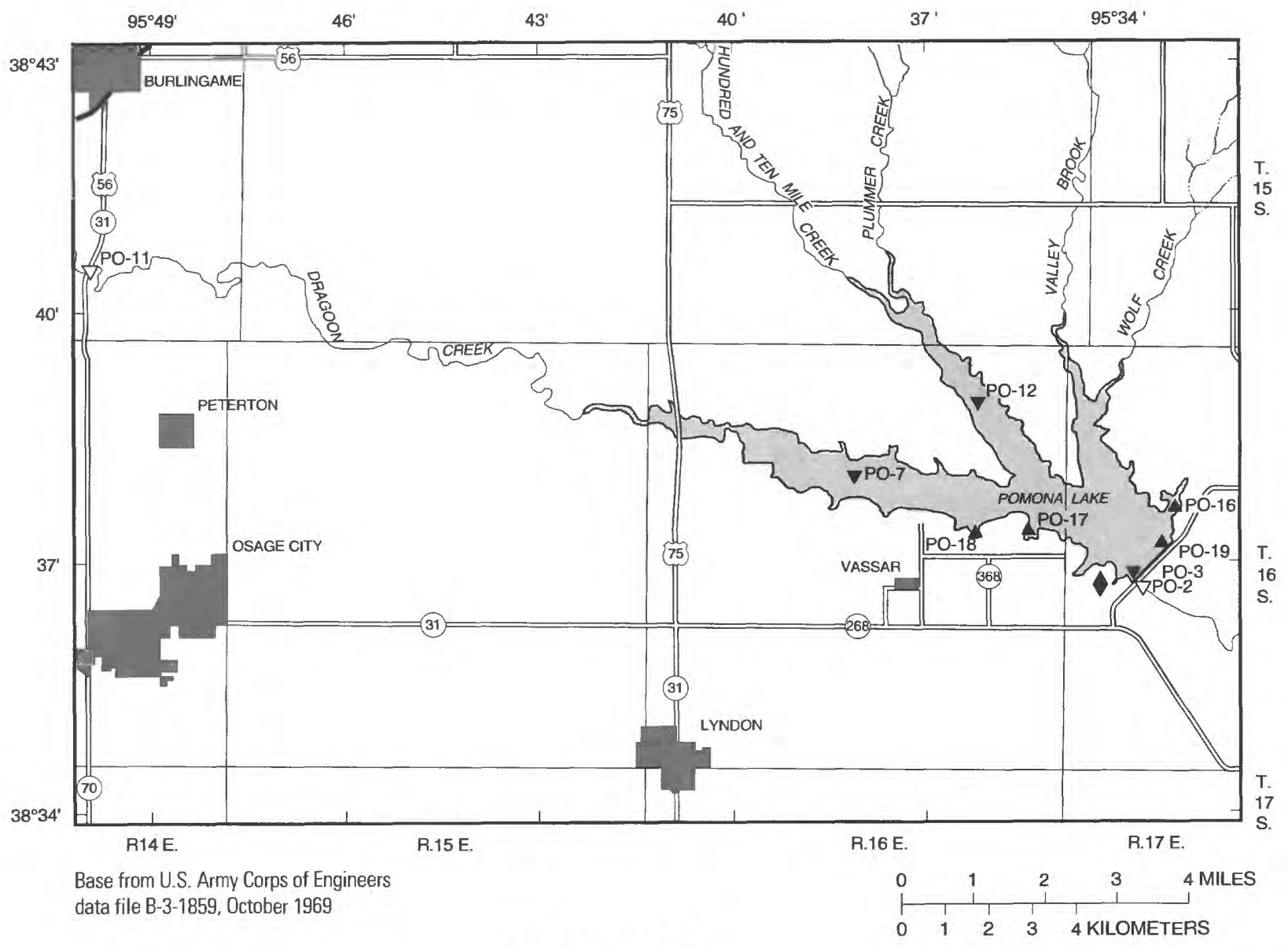

EXPLANATION

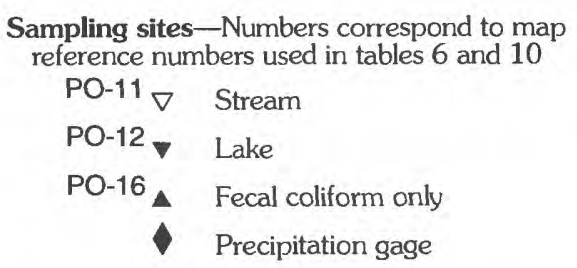

Figure 4. Location of sampling sites at Pomona Lake, Kansas (reservoir shown at multipurpose-pool elevation).

near the center of streamflow. Air space in the top of the bottle was minimized to limit the exchange of carbon dioxide from the sample water. Alkalinity samples were chilled and maintained at $4{ }^{\circ} \mathrm{C}$ until analysis onsite in a mobile water-quality laboratory within 6 hours of sample collection.

Samples for fecal coliform analysis were collected in a sterile, autoclaved, 1-L, wide-mouth polyethylene bottle at the center of streamflow. The bottle was inverted so that the bottle opening was facing the surface of the water. The bottle was lowered straight down until the bottle was completely submerged, then turned upright gradually in a radial motion while underwater. The bottle then was capped, chilled, and maintained at $4{ }^{\circ} \mathrm{C}$ until processed onsite in the mobile laboratory within 6 hours of collection. Air space was left in the bottle to allow thorough mixing before processing.

A clean 500-mL graduated cylinder was used to collect samples for herbicide analysis. Subsamples were collected from the churn splitter for analysis of additional chemical properties and constituents at the USGS laboratory in Arvada, Colo. Processing and analytical methods are described in later sections of this report. 


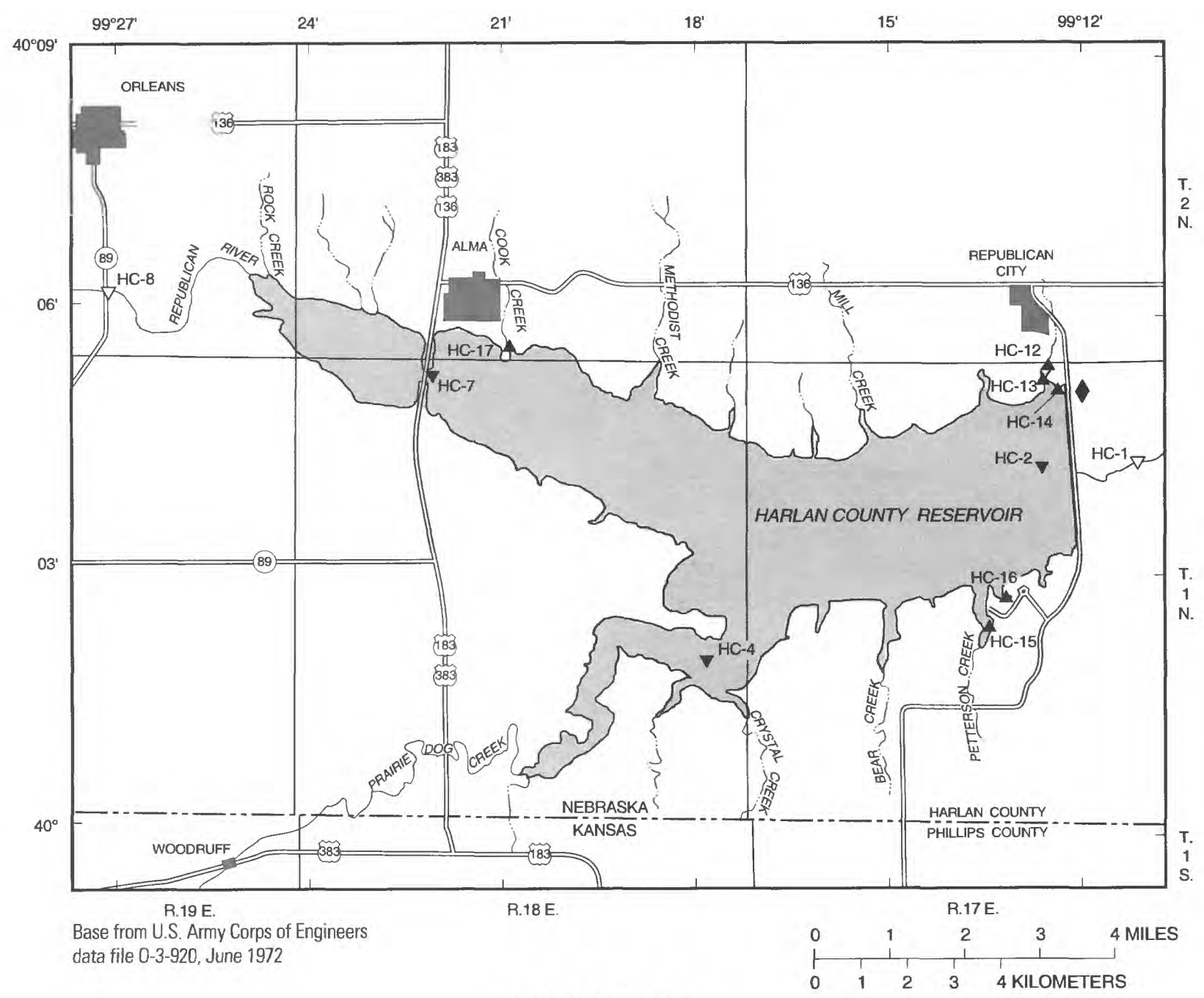

EXPLANATION

Sampling sites-Numbers correspond to map reference numbers used in tables 7 and 11

$\begin{aligned} \mathrm{HC}^{\mathrm{H}}{ }^{\mathrm{HC}-7} \nabla & \text { Stream } \\ \mathrm{HC}^{\mathrm{H}}-17 & \text { Lake } \\ & \text { Fecal coliform only } \\ & \text { Precipitation gage }\end{aligned}$

Figure 5. Location of sampling sites at Harlan County Reservoir, Nebraska (reservoir shown at multipurpose-pool elevation).

\section{Reservoir Sampling}

Water samples from the reservoirs were collected from a boat using a pre-cleaned churn splitter for the $0.1-\mathrm{m}(0.33-\mathrm{ft})$ depth surface sample and a pre-cleaned Teflon Kemmerer ${ }^{1}$ sampler to

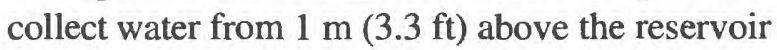

\footnotetext{
${ }^{1}$ The use of brand names in this report is for identification purposes only and does not constitute endorsement by the U.S. Geological Survey.
}

bottom. The Kemmerer sampler was lowered to the desired sampling depth with two stoppers open. A messenger (a cylindrical weight that slides down the rope) triggered and closed the sampler. The sampler then was retrieved, and the contents emptied into a clean churn splitter. This process was repeated until the churn splitter was nearly full. Water also was emptied from the Kemmerer sampler into a $500-\mathrm{mL}$ polyethylene bottle for alkalinity analysis. The bottle was filled so that there was no air space. 
Table 3. Sampling sites at Rathbun Reservoir, lowa, Clinton and Pomona Lakes, Kansas, and Harlan County Reservoir, Nebraska

[*, Fecal coliform only; +, all constituents including fecal coliform]

\begin{tabular}{llll}
\hline \multirow{2}{*}{ Reservoir or lake } & \multicolumn{3}{c}{ Site code } \\
\cline { 2 - 4 } Rathbun (fig. 2) & $\begin{array}{l}\text { RA-3, RA-7, } \\
\text { RA-8, RA-16*, }\end{array}$ & $\begin{array}{l}\text { RA-12, } \\
\text { RA-15+ }\end{array}$ & RA-28 \\
& RA-18*, RA-20*, & & \\
& RA-31* & & \\
Clinton (fig. 3) & CL-2, CL-6, & CL-16 & CL-1 \\
& CL-13, CL-20, & & \\
& CL-22*, CL-23*, & & \\
Pomona (fig. 4) & CL-24* & & \\
& PO-3, PO-7, & PO-11 & PO-2 \\
& PO-12, PO-16*, & & \\
& PO-17*, PO-18*, & & \\
Harlan County & PO-19* & & \\
(fig. 5) & HC-2, HC-4, & HC-8 & HC-1 \\
& HC-7, HC-12*, & & \\
& HC-13*, HC-14*, & & \\
& HC-15*, HC-16*, & & \\
\hline
\end{tabular}

Water samples for fecal coliform analysis were collected at specified sites on the reservoirs (table 3 ). These samples were collected at a depth of $0.1 \mathrm{~m}$ $(0.3 \mathrm{ft})$ or less. Samples were collected as described in the section on "Inflow and Outflow Sampling."

Samples for herbicide analysis were collected in a $500-\mathrm{mL}$ graduated cylinder at a depth of $0.1 \mathrm{~m}$ $(0.33 \mathrm{ft})$. Samples for herbicide analysis from $1 \mathrm{~m}$ ( $3.3 \mathrm{ft}$ ) above the bottom of the reservoir were collected using the Teflon Kemmerer sampler and transferred to a graduated cylinder.

Water samples for chlorophyll- $a$ and $-b$ analysis were collected at reservoir sites (table 3 ). A sampler was constructed from a $4.5-\mathrm{m}$ (15-ft) length of 1.25 -in. inside-diameter PVC pipe, with a ball-check valve mounted in one end of the pipe. Samples were collected by holding the sampler in a vertical position so that the ball-check valve was on the bottom and then lowering the sampler until the bottom of the sampler reached the desired depth at the bottom of the photic zone (1-percent light-penetration depth). When the sampler was removed from the water, it was tipped so that the water in the sampler poured out the open end and into a clean churn splitter used exclusively for chlorophyll samples. This process was repeated until the churn splitter contained approximately $7 \mathrm{~L}$. The chlorophyll samples were processed (this process is discussed in the sample processing and preservation section), the remaining water was discarded, and the churn was used for the collection of the water sample at the $0.1-\mathrm{m}(0.33 \mathrm{ft})$ depth.

Subsamples were collected from the churn splitter during sample processing for analysis of additional chemical properties or constituents at the USGS laboratory in Arvada, Colo. The methods used for collection, processing, preservation, and analysis of subsamples are described in a later section of this report.

\section{Onsite Sample Processing and Preservation for Laboratory}

Water samples were processed and preserved in a mobile water-quality laboratory. PVC gloves were worn at all times during sample processing and preservation. Raw, unfiltered subsamples (total and total recoverable) were collected from the churn splitter, after mixing for 15 seconds, for later analysis at the USGS laboratory for turbidity, COD, alkalinity, TSS, major ions, nutrients (nitrogen and phosphorous species), selected trace metals, and TOC. All bottles were rinsed with sample water and then filled, except for COD, TOC, and herbicide bottles. COD, TOC, and herbicide bottles were sterilized because rinsing the bottles may contaminate the samples. After the bottles were filled, they were set aside to be preserved. The water remaining in the churn splitter was used for filtered samples.

A preservation chamber was used to reduce potential ambient air contamination from dust during the sample-preservation process. The preservation chamber was about $1.5 \mathrm{ft}$ wide, $0.75 \mathrm{ft} \mathrm{high,} 1.5 \mathrm{ft}$ deep, and lined with a clear plastic bag. The samples and preservation ampules were placed inside the chamber. The caps were removed from the bottles, and the preservatives were added to the samples in the following order: nitric acid, sulfuric acid, and mercuric chloride. The caps were replaced on the bottles, the samples were removed from the chamber, and placed in a cooler. The clear plastic bag and PVC gloves were discarded between preservatives and between sample sets.

Turbidity samples were collected from the churn splitter in a $250-\mathrm{mL}$ polyethylene bottle and sent to the USGS laboratory in Arvada, Colo., for analysis. COD samples were collected in 125 -mL baked- (at $450^{\circ} \mathrm{C}$ ) glass amber bottles, $1 \mathrm{~mL}$ of concentrated sulfuric acid was added, and the samples were chilled and main- 
tained at $4{ }^{\circ} \mathrm{C}$ until they were submitted to the laboratory for analysis. Samples for total and totalrecoverable metals (calcium, magnesium, sodium, iron, manganese, and zinc) were collected in a $250-\mathrm{mL}$ nitric acid-rinsed polyethylene bottle and preserved with $1 \mathrm{~mL}$ of concentrated nitric acid. TSS samples were collected in a 500-mL polyethylene bottle and sent to the laboratory for analysis. Total nutrient samples (total ammonia plus organic nitrogen and total phosphorous) were collected in a $125-\mathrm{mL}$ brown polyethylene bottle. The samples were preserved with $0.5 \mathrm{~mL}$ of mercuric chloride, added as a biocide, and then chilled and maintained at $4{ }^{\circ} \mathrm{C}$ until analysis at the laboratory. TOC samples were collected in a 125 -mL baked-glass amber bottle and chilled and maintained at $4{ }^{\circ} \mathrm{C}$ until analysis at the USGS laboratory.

Samples analyzed for filtered (dissolved) constituents were filtered using a peristaltic pump as a pressure source and a reservoir-dedicated 0.25 -in. diameter silicon hose to pump the sample water from the churn splitter through a disposable $0.45-\mu \mathrm{m}$ (micrometer) capsule filter. The bottles were filled inside a clean processing chamber to reduce possible ambient air contamination. The processing chamber consisted of a $1.5 \mathrm{ft}$ by $1.5 \mathrm{ft}$ by $1.5 \mathrm{ft}$ PVC frame and a clear plastic bag. A silicon hose was inserted through a hole at the top of the chamber, and the disposable capsule filter was connected to the end of the hose. A hole in the bottom of the chamber allowed excess water to escape. The filter was conditioned with $1 \mathrm{~L}$ of deionized water [specific conductance less than $1 \mu \mathrm{S} / \mathrm{cm}$ (microsiemen per centimeter at $25^{\circ} \mathrm{C}$ )], followed by $200 \mathrm{~mL}$ of sample water. Sample bottles were rinsed and filled inside the chamber. Sample bottles for filtered metal analysis were filled first, followed by bottles used for anions and nutrients. When filtering was completed, the caps of the bottles were replaced. A new plastic bag and capsule filter were installed between each sample process. Silicon tubing, dedicated to each reservoir, was cleaned between site visits with detergent and diluted hydrochloric acid.

To determine concentrations of filtered (dissolved) anions (sulfate and chloride), nutrients (nitrite, nitrite plus nitrate, ammonia, and orthophosphate), and selected metals (iron, manganese, and zinc), samples were processed and preserved in the mobile water-quality laboratory and were sent to the USGS laboratory for analysis. Samples for analysis of metals were collected in acid-rinsed, $250-\mathrm{mL}$ polyethylene bottles. These samples were preserved with $1 \mathrm{~mL}$ of concentrated nitric acid to adjust the $\mathrm{pH}$ to less than 2.0 standard units. Anion samples were collected in 250-mL polyethylene bottles. Dissolved nutrient samples were collected in $125-\mathrm{mL}$ brown polyethylene bottle, preserved with $0.5 \mathrm{~mL}$ of mercuric chloride, and chilled and maintained at $4{ }^{\circ} \mathrm{C}$ until analyzed at the USGS laboratory. All samples were processed and preserved within 6 hours of sample collection and were sent to the USGS laboratory in Arvada, Colorado, within 5 days.

Herbicide samples filtered through a $0.7-\mu \mathrm{m}$ glass-fiber filter using a peristaltic pump and a vacuum flask. The vacuum flask was rinsed with methanol prior to use. The filter and flask were rinsed with $250 \mathrm{~mL}$ of sample water, and the filtrate was discarded. After rinsing, about $250 \mathrm{~mL}$ of sample water were filtered, and two 125 -mL baked-glass amber bottles were filled with filtrate and chilled and maintained at $4{ }^{\circ} \mathrm{C}$ until analyzed.

A known volume $(100,250,500$, or $1,000 \mathrm{~mL})$ of water from the churn splitter was filtered through a $0.7-\mu \mathrm{m}$ glass fiber filter for analysis of the chlorophyll- $a$ and $-b$ concentrations. The filters were removed with stainless-steel forceps, folded in half, placed in petri dishes, wrapped in aluminum foil, and frozen until analysis at the laboratory. A split sample was filtered at each site to ensure that there was a sufficient amount of chlorophyll for analysis.

\section{Onsite Analysis}

Physical and chemical properties determined at the time of or within 6 hours of sample collection were reservoir water-surface elevation, stream discharge, stream stage, specific conductance, $\mathrm{pH}$, water temperature, transparency (secchi disk and 1-percent light-penetration depth), barometric pressure, DO, fecal coliform, and alkalinity (including bicarbonate and carbonate). These physical and chemical properties were determined using methods described by Ward and Harr (1990) and Wells and others (1990).

The USGS has reservoir-gaging stations at the dams of all four reservoirs that continuously record the elevation of the water surface. The water-surface elevation at the time of sample collection was noted.

Discharge at each stream sampling site, except for site RA-12 on the South Fork Chariton River in Iowa (fig. 2), was determined using data from nearby 
USGS streamflow-gaging stations. At these gaging stations, data are collected to generate rating curves that establish a relation between the discharge and the stage of a stream. Before sample collection, the discharge of the stream at the sampling site was estimated from the gaging-station rating curve. Before sampling at site RA-12 where no USGS gaging station exists, the stream discharge was measured using methods described by Buchanan and Somers (1969).

Specific conductance, $\mathrm{pH}$, water temperature, and DO were measured using a multiparameter analysis unit. The unit was calibrated using standard solutions with approximately the same property and constituent values as the sampled water. The specific conductance, $\mathrm{pH}$, and DO were compensated for temperature and expressed in microsiemens per centimeter at $25^{\circ} \mathrm{C}$, standard units, and milligrams per liter, respectively. A thermistor measured water temperature to the nearest $0.5^{\circ} \mathrm{C}$. Barometric pressure was measured with a calibrated barometer.

Water transparency was determined using two different instruments-a secchi disk and a photometer. The secchi disk is a $20-\mathrm{cm}$ (centimeter) (7.9-in.) diameter disk. The painted surface of the disk is divided into black and white quarters. The disk was lowered into the reservoir to a depth at which the disk disappeared and then raised until the disk reappeared. The mean depth of the point where the disk disappeared and appeared was recorded. The photometer consists of a sensor, cord, and meter. The sensor detects light and sends a signal to the meter, which displays the amount of light detected. First, the amount of light above the water surface was measured and recorded. One percent of this amount was calculated and recorded. The sensor then was lowered into the water until the meter reading was 1 percent of the reading above the water surface, and that depth was recorded.

To determine fecal coliform concentrations, sterilized filter holders and sterile $0.65-\mu \mathrm{m}$ membranes were used to remove the fecal coliform bacteria from the water sample. A blank sample of sterile buffer water was filtered before filtering each sample. Predetermined sample volumes $(1,3,10,30$, and $100 \mathrm{~mL}$ ) were filtered through individual filters. After the $100-\mathrm{mL}$ sample was filtered, the equipment was cleaned with sterile buffer water, and an end sample blank was processed. The filters from the sample blank and the sample volumes were placed in a petri dish on a surface of M-FC media agar. The agar-filled petri dishes were prepared within 72 hours of processing and were stored at $4{ }^{\circ} \mathrm{C}$ until they were used. The petri dishes with the agar and filter were incubated at $44.0^{ \pm} 0.5^{\circ} \mathrm{C}$ for 22 to 24 hours. The fecal coliform bacteria colonies were counted and reported as total colonies per $100 \mathrm{~mL}$ of water. Colony counts outside of the range of 20 to 60 colonies per $100 \mathrm{~mL}$ were reported as nonideal counts.

Alkalinity measurements were made within 6 hours of sample collection using a portable $\mathrm{pH}$ meter, a titrator, and a magnetic stirrer. Increments of 0.16 normal sulfuric acid were added to $50 \mathrm{~mL}$ of unfiltered sample water until the $\mathrm{pH}$ reached a value of less than 4.0. The increments of acid and the corresponding $\mathrm{pH}$ were recorded. The alkalinity, bicarbonate, and carbonate concentrations were calculated using methods described by Wells and others (1990). The incremental titration endpoint usually was at a $\mathrm{pH}$ value of about 4.5 . Each sample was analyzed at least twice, and values were required to be within 4 percent before the value was reported.

\section{Laboratory Analysis}

Samples were analyzed for concentrations of the remaining properties and constituents at the USGS laboratory (NWQL) in Arvada, Colorado (Wershaw and others, 1987; Britton and Greeson, 1989; Fishman and Friedman, 1989). Samples were analyzed for concentrations of triazine herbicides by ELISA and GC/MS at the USGS laboratory in Lawrence, Kansas (Thurman and others, 1990; Pomes and Thurman, 1991).

The turbidity of samples was determined using method I-3860-85 (Fishman and Friedman, 1989). This method is based on a comparison of the intensity of light scattered by a sample with intensity of light scattered by a standard reference suspension under the same defined conditions. Results are reported in nephelometric turbidity units (NTU).

COD concentrations were determined using method I-3561-85 (Fishman and Friedman, 1989). An acid-dichromate solution is used to oxidize organic and other oxidizable materials by digestion in the presence of silver sulfate. By measuring the absorbance of the chromium that is formed, the concentration of COD is determined spectrometrically.

Total-recoverable concentrations of calcium, magnesium, and sodium were determined using methods described by Fishman and Friedman (1989). 
Total-recoverable calcium and magnesium were determined by methods I-3152-85 and I-3447-85, respectively. To mask interferences, lanthanum chloride was added in each method. Total-recoverable sodium was determined by method I-3735-85, which involves direct aspiration of the sample solution into an air-acetylene flame.

Sulfate and chloride concentrations were determined using method I-2057-85 (Fishman and Friedman, 1989). This method determines six anions sequentially by ion-exchange chromatography. Ions are separated on the basis of their affinity for the exchange sites on the host resin. Using an electricalconductivity cell, separated anions were measured in the acid form.

Total suspended solids (TSS) were determined using method I-3765-85 (Fishman and Friedman, 1989). TSS are those solids that are retained on a glass-fiber filter. The insoluble residue was dried at $105^{\circ} \mathrm{C}$.

Samples were analyzed for concentrations of dissolved nitrite and dissolved nitrite plus dissolved nitrate, both as nitrogen, using methods I-2540-90 and I-2545-90. Nitrite ion under acidic conditions reacts with sulfanilamide to form a diazo compound. This compound then couples with N-1-naphthylethylenediamine dihydrochloride to form a red compound, the absorbance of which is measured colorimetrically. Nitrite plus nitrate was determined by the same method after the nitrate was reduced to nitrite by a copper-cadmium column.

Samples were analyzed for concentrations of ammonia using method I-2522-90. Ammonia in the sample reacts with sodium nitroprusside, sodium hypochlorite, and sodium salicylate in an alkaline medium to form an intensely colored compound. The concentration of ammonia present is directly proportional to the resulting color.

Concentrations of total ammonia plus organic nitrogen were determined using method I-4515-91 (Fishman, 1993). Organic nitrogen compounds are reduced to the ammonium ion by digestion with sulfuric acid in the presence of mercuric sulfate (a catalyst) and potassium sulfate. The ammonium ion produced, as well as the original ammonium ion present, is determined by reaction with sodium salicylate, sodium nitroprusside, and sodium hypochlorite in an alkaline medium. The concentration of ammonia plus organic nitrogen present is directly proportional to the resulting color.
Total phosphorous as phosphorous concentrations were determined using method $\mathrm{I}-4610-91$ (Patton and Truit, 1992). Organic phosphorous compounds are reduced to orthophosphate by digestion with sulfuric acid in the presence of mercuric sulfate (a catalyst) and potassium sulfate. The orthophosphate produced, as well as the original orthophosphate present, is determined by reaction with sodium salicylate, sodium nitroprusside, and sodium hypochlorite in an alkaline medium. The concentration of phosphorous present is directly proportional to the resulting color.

Dissolved orthophosphate as phosphate concentrations were determined using method I-2601-90. An acidified ammonium molybdate reagent converts orthophosphate to phosphomolybdic. The phosphomolybdic is reduced with ascorbic acid in the presence of antimony, producing an intense blue color.

Total-recoverable concentrations of iron, manganese, and zinc were analyzed using methods I-3381-85, I-3454-85, and I-3900-85, respectively. Dissolved concentrations of iron, manganese, and zinc were analyzed at the NWQL using methods I-1381-85, I-1454-85, and I-1900-85, respectively. Concentrations of these constituents were determined by atomic absorption spectrometry, which involves direct aspiration of the sample solution into an airacetylene flame. For manganese analysis, the sample is aspirated into the air-acetylene flame without preconcentration or pretreatment.

TOC concentrations were determined at the NWQL using method O-3100-83 (wet oxidation) (Wershaw and others, 1987). The acidified sample is purged to remove forms of inorganic carbon and oxidized with persulfate in an autoclave at 116 to $130{ }^{\circ} \mathrm{C}$. Nondispersive infrared spectrometry measures the resultant carbon dioxide.

Total triazine herbicide concentrations in water samples were determined at the USGS laboratory in Lawrence, Kansas, by enzyme-linked immunosorbent assay (ELISA) (Pomes and Thurman, 1991). The method used by Thurman and others (1990) was repeated with minor differences. The microtiter-plate kits consist of 96 individual wells coated with polyclonal antibodies. Eighty microliters of sample blanks, atrazine standards, or water samples were placed in each well. Deionized water was used for the sample blanks, and atrazine standard concentrations were $0.1,0.5$, and $5.0 \mu \mathrm{g} / \mathrm{L}$ (micrograms per liter). Immediately, $80 \mu \mathrm{L}$ (microliters) of enzyme conjugate 
were added to each of the wells. The plates were incubated simultaneously at $35^{\circ} \mathrm{C}$ and mixed on an orbital shaker for 1 hour. The plate wells were gently emptied, rinsed, and dried, without disturbing the bound media. Next, $160 \mu \mathrm{L}$ of substrate-chromogen mixture were added to each well. The plate was incubated and shaken for an additional 30 minutes. This step produced a blue color in each well, with a shade proportional to the triazine concentration of the sample. A yellow color is produced with the addition of $40 \mu \mathrm{L}$ of 2.5 normal sulfuric acid. Then the microtiter plate was inserted into a plate reader. The plate reader consisted of a spectrophotometer that measured the optical density of each well simultaneously. The optical density output from the plate reader was processed by a computer to calculate triazine concentrations. Concentrations were reported in micrograms per liter as atrazine. This method cross reacts with all of the triazine herbicides (Pomes and Thurman, 1991).

Filtered triazine and acetanilide herbicide concentrations were determined by gas chromatography/mass spectrometry (GC/MS) at the USGS laboratory in Lawrence, Kansas (Thurman and others, 1990). Samples were extracted onto cartridges and eluted with ethyl acetate. The solutions were evaporated to $100 \mu \mathrm{L}$ and analyzed on a gas chromatograph and a mass-selective detector.

Chlorophyll- $a$ and $-b$ concentrations were determined at the NWQL using method B-6540-85 (Britton and Greeson, 1989). This method extracts chlorophyll from algal cells and separates them from each other and chlorophyll degradation products by thin-layer chromatography. Chlorophyll is eluted and measured using a spectrofluorometer.

\section{Quality Assurance}

A duplicate sample was collected at each reservoir for each sampling period. A sample blank and a set of reference water samples were analyzed for each of the two sampling periods. Duplicate split samples were subsamples from the churn splitter and were processed, preserved, and analyzed using the same methods as the actual samples. During the first sampling, deionized water was used for the sample blank; certified inorganic and organic blank water was used for the second sample blank. The samplers were filled with blank water, emptied into the churn splitter, and processed, preserved, and analyzed using the same methods for actual samples. Reference water samples were obtained from the USGS NWQL in Arvada, Colorado. Spike mixtures were added to organic blank water as a reference sample for herbicide analyses.

These samples were furnished with the most probable value of the concentration for each constituent analyzed. Bottles for the selected constituents were filled with the reference water sample, processed, preserved, and analyzed using the same methods for actual samples. Results of these quality-assurance samples are presented in tables 4-7 at the end of this report.

\section{SUMMARY OF WATER-QUALITY CONDITIONS}

Results of analyses are summarized in the following paragraphs for each reservoir sampled. Discussion and presentation of the data in tables 4-7 at the end of this report are arranged in order by sites from upstream to downstream and by sample depth. Data for the vertical profiles of specific conductance, $\mathrm{pH}$, water temperature, and DO are presented in tables 8-11 at the end of this report and for the sites in each of the reservoirs nearest the dam in figure 6.

\section{Rathbun Reservoir, lowa}

Water samples from Rathbun Reservoir were collected from inflow, reservoir, and the outflow sites in early June and again in early August 1993 (table 4). Precipitation from May through August 1993 at Rathbun Reservoir was 12.62 in. more than the longterm mean precipitation during these same months at Centerville, Iowa (National Oceanic and Atmospheric Administration, 1951-80, table 1). The elevation of the reservoir water surface as measured at the dam was $9 \mathrm{ft}$ above multipurpose-pool elevation (904 ft) at about $913 \mathrm{ft}$ in June (table 4), and at the flood-controlpool elevation (926 ft) in August. Water at reservoir sampling site RA-3 was thermally stratified in August (fig. 6 and table 8).

Stage and flow conditions were above average at the Chariton River site (RA-15) (Southard and others, 1994) and the South Fork Chariton River site (RA-12) (Fischer and others, 1990) in June and August 1993 (table 4). Turbidity, COD, fecal coliform, TSS, total nitrogen, total-recoverable iron, totalrecoverable manganese, and TOC concentrations for the two stream sites were largest in June. Fecal coli- 

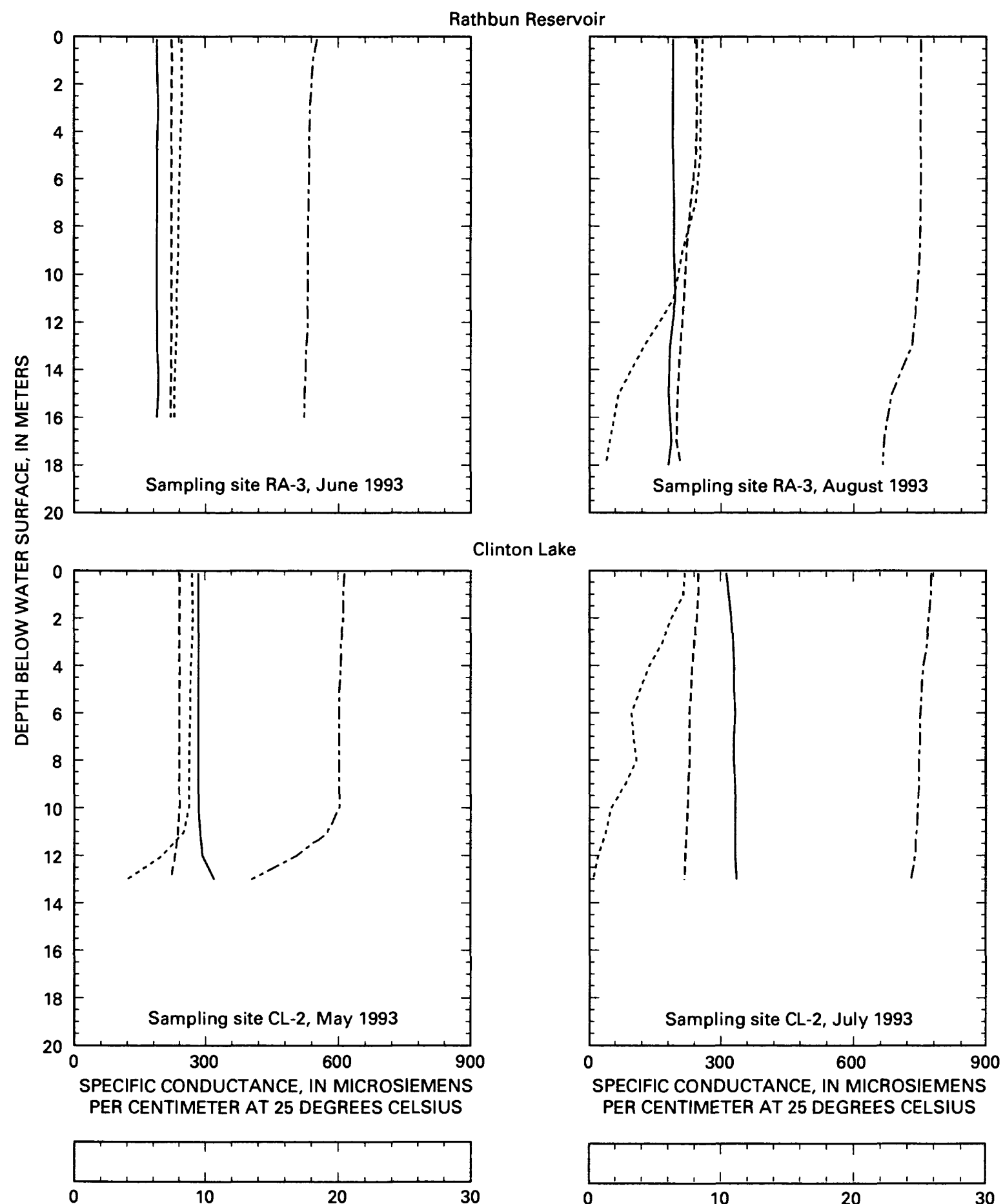

PH, IN STANDARD UNITS

WATER TEMPERATURE, IN DEGREES CELSIUS

DISSOLVED OXYGEN, IN MILLIGRAMS PER LITER

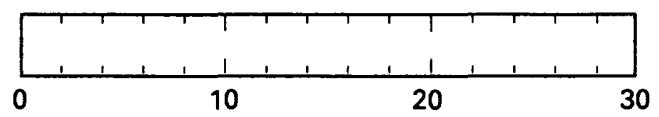

PH, IN STANDARD UNITS

WATER TEMPERATURE, IN DEGREES CELSIUS DISSOLVED OXYGEN, IN MILLIGRAMS PER LITER

\section{EXPLANATION}

$\begin{array}{ll}\text { Specific conductance } & --- \text {. Temperature } \\ ---- \text { pH } & \text {-..... Dissolved oxygen }\end{array}$

Figure 6. Vertical profiles of specific conductance, $\mathrm{pH}$, water temperature, and dissolved oxygen at sampling sites $\mathrm{RA}-3$ in Rathbun Reservoir, lowa, CL-2 in Clinton Lake, Kansas, PO-3 in Pomona Lake, Kansas, and HC-2 in Harlan County Reservoir, Nebraska. 

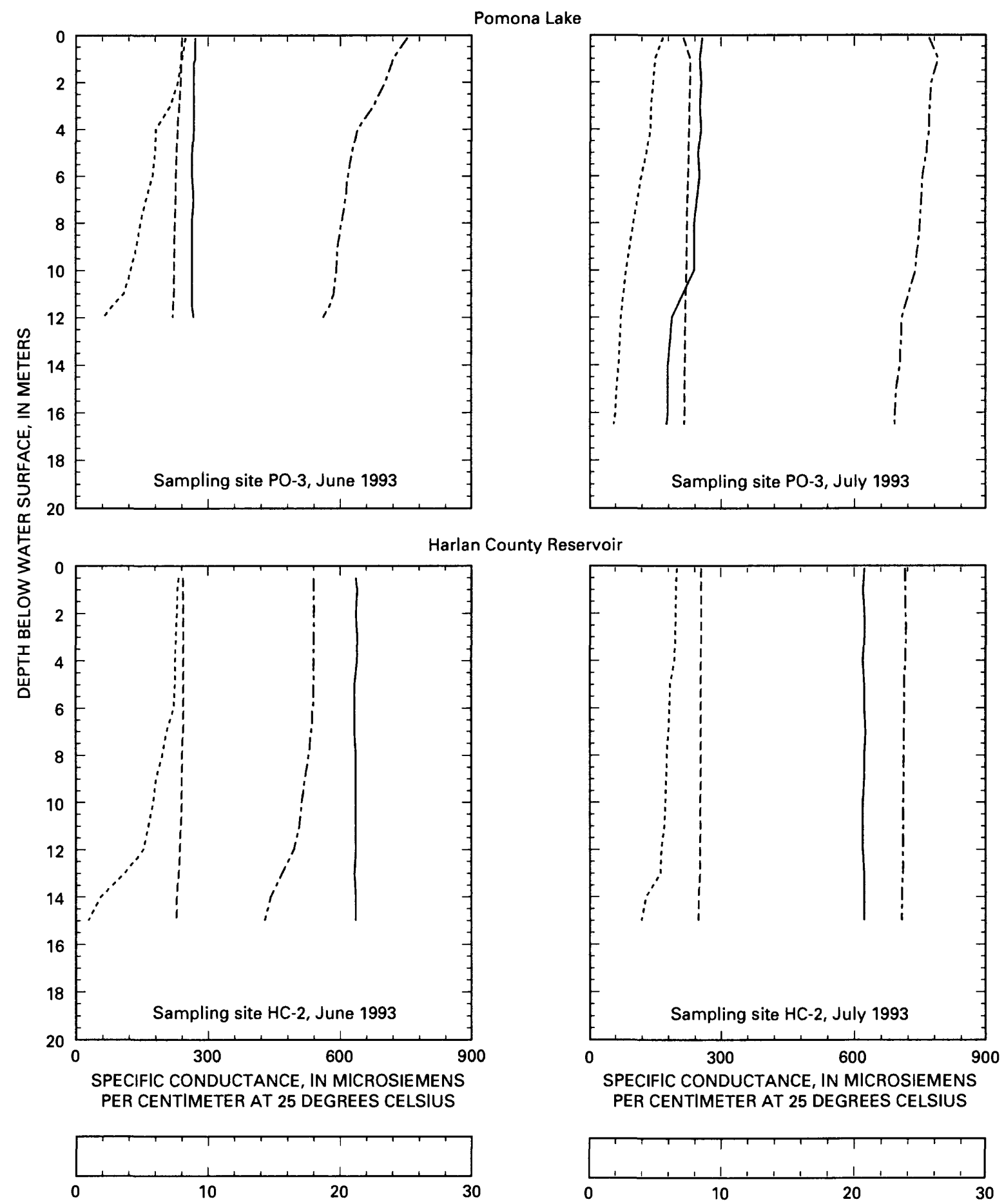

PH, IN STANDARD UNITS

WATER TEMPERATURE, IN DEGREES CELSIUS DISSOLVED OXYGEN, IN MILLIGRAMS PER LITER

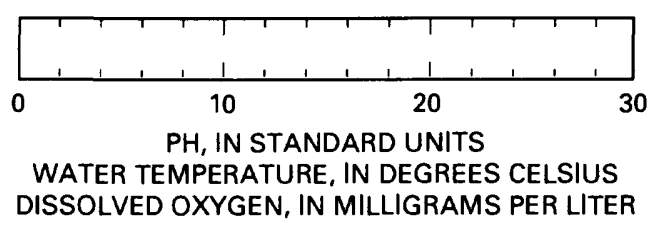

EXPLANATION

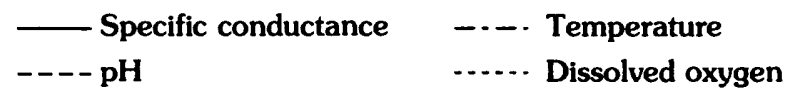

Figure 6. Vertical profiles of specific conductance, $\mathrm{pH}$, water temperature, and dissolved oxygen at sampling sites RA-3 in Rathbun Reservoir, lowa, CL-2 in Clinton Lake, Kansas, PO-3 in Pomona Lake, Kansas, and HC-2 in Harlan County Reservoir, Nebraska-Continued. 
form concentrations ranged from 1 to $610 \mathrm{cols} / 100 \mathrm{~mL}$ (colonies per 100 milliliters) and were largest at the inflow site RA-15 in June. ELISA total triazine herbicide concentrations, reported as atrazine, also were largest in samples collected in June and exceeded the U.S. Environmental Protection Agency (EPA) Maximum Contaminant Level (MCL) of $3.0 \mu \mathrm{g} / \mathrm{L}$ for atrazine in drinking water (U.S. Environmental Protection Agency, 1993) in samples from sites RA-15 and RA-12. The maximum concentration was $19 \mu \mathrm{g} / \mathrm{L}$ in water from site RA-12. Atrazine, cyanazine, and metolachlor were detected by GC/MS analysis at concentrations of $1.1,1.2$, and $0.24 \mu \mathrm{g} / \mathrm{L}$, respectively, in water from site RA-15 in August. Atrazine, cyanazine, and metolachlor were detected at concentrations of $0.67,0.42$, and $0.17 \mu \mathrm{g} / \mathrm{L}$, respectively, in water from site RA-12 in August. The cyanazine concentration in the water sample from site RA-15 in August exceeded the EPA lifetime Health Advisory Level (HAL) of $1.0 \mu \mathrm{g} / \mathrm{L}$ (U.S. Environmental Protection Agency, 1993).

At reservoir sites RA-7, RA-8, and RA-3, turbidity, COD, TSS, total-recoverable iron, and TOC concentrations were largest in samples collected in June. The largest ELISA total triazine herbicide concentration, reported as atrazine, was $15 \mu \mathrm{g} / \mathrm{L}$ in water from site RA-8 in June. The smallest ELISA total triazine herbicide concentration, reported as atrazine, was $0.6 \mu \mathrm{g} / \mathrm{L}$ in water from reservoir sites RA-3 and RA-7 in June. Total triazine samples collected in June and August at sites RA-7 and RA-8 and at site RA-3 in August exceeded the EPA MCL of $3.0 \mu \mathrm{g} / \mathrm{L}$ for atrazine in drinking water. Samples analyzed for cyanazine concentrations by GC/MS in August exceeded the EPA HAL of $1.0 \mu \mathrm{g} / \mathrm{L}$ for cyanazine in water from reservoir sites RA-7, RA-8, and RA-3. Other herbicides detected in water samples were alachlor and metolachlor, but concentrations were less than EPA MCLs and HALs for these herbicides. The maximum chlorophyll- $a$ concentration was $41 \mu \mathrm{g} / \mathrm{L}$ in water from reservoir site $\mathrm{RA}-3$ in August. The minimum chlorophyll- $a$ concentration was $1.8 \mu \mathrm{g} / \mathrm{L}$ in water from reservoir site RA-3 in June.

Fecal coliform samples were collected in Rathbun Reservoir near swimming beaches and marinas at sites RA-20, RA-18, RA-16, and RA-31. Fecal coliform concentrations in samples from these sites ranged from 1 to 200 cols $/ 100 \mathrm{~mL}$ of water and were largest in June.
At the reservoir outflow site (RA-28), the flow was $11 \mathrm{ft}^{3} / \mathrm{s}$ in June and $1,200 \mathrm{ft}^{3} / \mathrm{s}$ in August. The largest turbidity and concentrations of TSS, totalrecoverable iron, total-recoverable manganese, and TOC occurred in June. The outflow sample from Rathbun Reservoir had an atrazine concentration of $2.9 \mu \mathrm{g} / \mathrm{L}$ in August and also exceeded the EPA HAL of $1.0 \mu \mathrm{g} / \mathrm{L}$ for cyanazine. Alachlor $(0.13 \mu \mathrm{g} / \mathrm{L})$, atrazine $(2.9 \mu \mathrm{g} / \mathrm{L})$, cyanazine $(3.7 \mu \mathrm{g} / \mathrm{L})$, and metolachlor $(0.47 \mu \mathrm{g} / \mathrm{L})$ concentrations were detected by GC/MS analysis in samples collected from site RA-28 in August.

\section{Clinton Lake, Kansas}

Water samples from Clinton Lake were collected from inflow, reservoir, and outflow sites in late May and mid-July 1993 (table 5). Precipitation from May through August 1993 at Clinton Lake was 10.30 in. more than the long-term mean precipitation during these months at Lawrence, Kansas (National Oceanic and Atmospheric Administration, 1951-80, table 1). The elevation of the reservoir water surface as measured at the dam was $6.5 \mathrm{ft}$ above multipurposepool elevation $(875.5 \mathrm{ft}$ ) at about $882 \mathrm{ft}$ in May and was $4.5 \mathrm{ft}$ above multipurpose-pool elevation at $880 \mathrm{ft}$ in July. Water at reservoir sites CL-13 and CL-2 was thermally stratified in May (fig. 6 and table 9).

Discharge at the Wakarusa River inflow site (CL-16) was estimated at $100 \mathrm{ft}^{3} / \mathrm{s}$ in May 1993 and measured at $350 \mathrm{ft}^{3} / \mathrm{s}$ in July 1993 (table 5). Turbidity, COD, TSS, total-phosphorous, total-recoverable iron, total-recoverable manganese, and TOC concentrations at this site were largest in July. The largest ELISA total triazine herbicide concentration at site $\mathrm{CL}-16$, reported as atrazine, was $6.8 \mu \mathrm{g} / \mathrm{L}$ in July and exceeded the EPA MCL for drinking water of $3.0 \mu \mathrm{g} / \mathrm{L}$ for atrazine. In July, alachlor, atrazine, metolachlor, and propazine were detected by GC/MS analysis at concentrations of $0.68,6.0,0.57$, and $0.06 \mu \mathrm{g} / \mathrm{L}$, respectively. The atrazine concentration exceeded the EPA MCL of $3.0 \mu \mathrm{g} / \mathrm{L}$.

At reservoir sampling sites CL-13, CL-20, $C L-6$, and $C L-2$, the largest COD concentration was $130 \mathrm{mg} / \mathrm{L}$ in water from reservoir site CL-20 in July. The largest total nitrogen concentration was $3.7 \mathrm{mg} / \mathrm{L}$ in water from reservoir site CL-20 in July. The largest concentration of total phosphorous was $0.74 \mathrm{mg} / \mathrm{L}$ in water from reservoir site CL-20 in July. The largest total manganese concentration was $680 \mu \mathrm{g} / \mathrm{L}$ in water 
from reservoir site CL-6 in May. The largest concentration of TOC was $11 \mathrm{mg} / \mathrm{L}$ in water from reservoir site $\mathrm{CL}-6$ in May and in water from reservoir site CL-13 in July. The largest ELISA total triazine herbicide concentration, reported as atrazine, was $6.1 \mu \mathrm{g} / \mathrm{L}$ in water from reservoir site CL-13 in July. None of the samples collected in May from the inflow, reservoir, and outflow sites exceeded the EPA MCL of $3.0 \mu \mathrm{g} / \mathrm{L}$ for atrazine in drinking water. Samples from Clinton reservoir sampling sites that were analyzed for atrazine concentrations by GC/MS in July exceeded the EPA MCL of $3.0 \mu \mathrm{g} / \mathrm{L}$ for atrazine in water from sites $\mathrm{CL}-13$ and $\mathrm{CL}-6$. Other herbicides detected in water samples were alachlor, metolachlor, propazine, and simazine, but concentrations were less than EPA MCLs and HALs for these herbicides in drinking water. The maximum chlorophyll- $a$ concentration was $730 \mu \mathrm{g} / \mathrm{L}$ in water from reservoir site CL-20 in July. Algal blooms were observed at reservoir site $\mathrm{CL}-20$ in July. The minimum chlorophyll- $a$ concentration was $3.9 \mu \mathrm{g} / \mathrm{L}$ in water from reservoir site CL-2 in May.

Fecal coliform samples were collected in Clinton Lake near swimming beaches and marinas at sites CL-22, CL-23, and CL-24. Fecal coliform concentrations ranged from 1 to $110 \mathrm{cols} / 100 \mathrm{~mL}$ of water and were largest in July at site CL-22.

The outflow at site CL-1 was an estimated $2,500 \mathrm{ft}^{3} / \mathrm{s}$ in May 1993. The largest turbidity and concentrations of TSS, total-recoverable iron, and TOC at the outflow also occurred in May. The largest ELISA total triazine herbicide concentration, reported as atrazine, was $0.9 \mu \mathrm{g} / \mathrm{L}$ in July. Atrazine, deethylatrazine, and metolachlor were detected by GC/MS analysis in samples collected in July. None of the samples exceeded the EPA MCL for atrazine.

\section{Pomona Lake, Kansas}

Water samples from Pomona Lake were collected from inflow, reservoir, and outflow sites in mid-June and late July 1993 (table 6). Precipitation from May through August at Pomona Lake was 7.76 in. more than the long-term mean precipitation during these months at Lyndon, Kansas (National Oceanic and Atmospheric Administration, 1951-80, table 1). The elevation of the reservoir water surface as measured at the dam was $2 \mathrm{ft}$ above multipurposepool elevation ( $974 \mathrm{ft}$ ) at about $976 \mathrm{ft}$ in June and was $19 \mathrm{ft}$ above multipurpose-pool elevation at $993 \mathrm{ft}$ in July. Water at reservoir site PO-3 was thermally stratified in June (fig. 6 and table 10).
Streamflow was $18 \mathrm{ft}^{3} / \mathrm{s}$ in June and $85 \mathrm{ft}^{3} / \mathrm{s}$ in July at the Dragoon Creek inflow site (PO-11). Turbidity, TSS, total-nitrogen, and total-recoverable iron concentrations in water from this site were largest in July. ELISA total triazine herbicide concentrations, reported as atrazine, were largest in June $(6.0 \mu \mathrm{g} / \mathrm{L})$ and exceeded the EPA MCL of $3.0 \mu \mathrm{g} / \mathrm{L}$ for atrazine in drinking water. In July, alachlor, atrazine, and metolachlor were detected by GC/MS analysis at concentrations of $0.33,1.6$, and $2.6 \mu \mathrm{g} / \mathrm{L}$, respectively.

In water from reservoir sites PO-7, PO-12, and PO-3, the largest turbidity value was 73 NTU from reservoir site PO-3 in July. The largest COD concentration was $37 \mathrm{mg} / \mathrm{L}$ in water from reservoir site PO-12 in July. The largest concentration of TSS was $359 \mathrm{mg} / \mathrm{L}$ in water from reservoir site PO-7 in June. The largest total-manganese concentration was $330 \mu \mathrm{g} / \mathrm{L}$ in water from reservoir site PO-7 at a depth of $2 \mathrm{~m}(6.6 \mathrm{ft})$ below the surface in June. The largest concentration of TOC was $8.6 \mathrm{mg} / \mathrm{L}$ at reservoir site PO-7 in June. ELISA total triazine herbicide concentrations, reported as atrazine, exceeded the EPA MCL of $3.0 \mu \mathrm{g} / \mathrm{L}$ for atrazine in June in water from reservoir sites PO-7 and PO-12 and in July in water from reservoir sites PO-7, PO-12, and PO-3. Samples analyzed for atrazine concentrations by GC/MS exceeded the EPA MCL of $3.0 \mu \mathrm{g} / \mathrm{L}$ for atrazine in water from reservoir site $\mathrm{PO}-7$ in June and from reservoir site PO-12 in July. Other herbicides detected in water samples were alachlor, cyanazine, metolachlor, metribuzin, and prometryn, but concentrations were less than EPA MCLs and HALs for these herbicides. The maximum chlorophyll- $a$ concentration was $35 \mu \mathrm{g} / \mathrm{L}$ in water from reservoir site PO-7 in June. The minimum chlorophyll- $a$ concentration was $1.6 \mu \mathrm{g} / \mathrm{L}$ in water from reservoir site PO-3 in July.

Fecal coliform samples were collected in Pomona Lake near swimming beaches and marinas at sites PO-18, PO-17, PO-16, and PO-19. Fecal coliform concentrations ranged from 1 to $110 \mathrm{cols} / 100 \mathrm{~mL}$ of water and were largest in July in water from site PO-17.

Streamflow was $15 \mathrm{ft}^{3} / \mathrm{s}$ at outflow site PO-2 in July. The largest concentrations of TSS, total iron, and TOC at this site occurred in July. The ELISA total triazine herbicide concentration, reported as atrazine, was $2.8 \mu \mathrm{g} / \mathrm{L}$ in June and $2.7 \mu \mathrm{g} / \mathrm{L}$ July. These concentrations did not exceed the EPA MCL of $3.0 \mu \mathrm{g} / \mathrm{L}$ for atrazine in drinking water. In July, atrazine and metolachlor were detected by GC/MS 
analysis at concentrations of $2.0 \mu \mathrm{g} / \mathrm{L}$ and $0.71 \mu \mathrm{g} / \mathrm{L}$, respectively.

\section{Harlan County Reservoir, Nebraska}

Water samples from Harlan County Reservoir were collected from inflow, reservoir, and outflow sites in early June and late July 1993 (table 7). Precipitation from May through August at Harlan County Reservoir was 12.35 in. more than the longterm mean precipitation during these months at Naponee, Nebraska (National Oceanic and Atmospheric Administration, 1951-80, table 1). The elevation of the reservoir water surface as measured at the dam was $1 \mathrm{ft}$ below multipurpose-pool elevation $(1,946 \mathrm{ft})$ at about $1,945 \mathrm{ft}$ in June and was $2 \mathrm{ft}$ above multipurpose-pool elevation at $1,948 \mathrm{ft}$ in July. Water at reservoir site $\mathrm{HC}-2$ was thermally stratified in June (fig. 6 and table 11).

Streamflow at the Republican River inflow site (HC-8) was $158 \mathrm{ft}^{3} / \mathrm{s}$ in June and $290 \mathrm{ft}^{3} / \mathrm{s}$ in July. Turbidity, COD, TSS, total-nitrogen, total-recoverable iron, total-recoverable manganese, and TOC concentrations at this site were largest in June. The ELISA total triazine herbicide concentration, reported as atrazine, was $2.6 \mu \mathrm{g} / \mathrm{L}$ in June and $1.6 \mu \mathrm{g} / \mathrm{L}$ in July and did not exceed the EPA MCL of $3.0 \mu \mathrm{g} / \mathrm{L}$ for atrazine in drinking water. In July, atrazine, cyanazine, and metolachlor were detected by GC/MS analysis at concentrations of $1.5,0.22$, and $0.73 \mu \mathrm{g} / \mathrm{L}$, respectively.

In water from reservoir sites $\mathrm{HC}-4, \mathrm{HC}-2$, and HC-7, the largest turbidity value (39 NTU) and TSS concentration $(38 \mathrm{mg} / \mathrm{L})$ were largest at site $\mathrm{HC}-7$ in July. The largest ELISA total triazine herbicide concentration, reported as atrazine, was $3.1 \mu \mathrm{g} / \mathrm{L}$ in water from reservoir site $\mathrm{HC}-7$ in June and exceeded the EPA MCL of $3.0 \mu \mathrm{g} / \mathrm{L}$ for atrazine in drinking water. None of the samples collected in July and analyzed by ELISA exceeded the EPA MCL for atrazine. None of the samples analyzed for atrazine concentrations by GC/MS in June or July exceeded the EPA MCL of $3.0 \mu \mathrm{g} / \mathrm{L}$ for drinking water. Other herbicides detected by GC/MS analysis in water samples were alachlor, cyanazine, and metolachlor, but concentrations were less than EPA MCLs and HALs for these herbicides. The maximum chlorophyll- $a$ concentration was $22 \mu \mathrm{g} / \mathrm{L}$ in water from reservoir site $\mathrm{HC}-7$ in July. The minimum chlorophyll- $a$ concentration was $1.2 \mu \mathrm{g} / \mathrm{L}$ in water from reservoir site $\mathrm{HC}-2$ in June.
Fecal coliform samples were collected in Harlan County Reservoir near swimming beaches and marinas at sites $\mathrm{HC}-17, \mathrm{HC}-15, \mathrm{HC}-16, \mathrm{HC}-12$, $\mathrm{HC}-13$, and HC-14. Fecal coliform concentrations ranged from 36 to 730 cols $/ 100 \mathrm{~mL}$ of water and were largest in July in water from site $\mathrm{HC}-17$.

Streamflow was $1.2 \mathrm{ft}^{3} / \mathrm{s}$ in June and $2.5 \mathrm{ft}^{3} / \mathrm{s}$ in July at outflow site HC-1. The largest concentrations of TSS, total-recoverable iron, total-recoverable manganese, and TOC in water from this site occurred in June. ELISA total triazine herbicide concentrations, reported as atrazine, were $1.1 \mu \mathrm{g} / \mathrm{L}$ in June and July and did not exceed the EPA MCL of $3.0 \mu \mathrm{g} / \mathrm{L}$ for atrazine in drinking water. In July, atrazine and metolachlor were detected by GC/MS analysis at concentrations of 0.75 and $0.08 \mu \mathrm{g} / \mathrm{L}$, respectively.

\section{QUALITY-ASSURANCE SAMPLES}

Results of the duplicate samples are presented in tables 4-7 at the end of this report. A few constituent concentrations are different between the sample and the sample duplicate. For example, the TSS concentration was less than $1.0 \mathrm{mg} / \mathrm{L}$ for a duplicate sample collected at reservoir site CL-2 in May, and the actual sample had a concentration of $5.0 \mathrm{mg} / \mathrm{L}$ (table 5). This difference can be caused by collecting an improper subsample from the churn splitter or analytical error.

Blank samples for reservoir site $\mathrm{PO}-7$ were analyzed at the completion of sampling at Pomona Lake in June and August. The source of the blank water in June was deionized water. This sample had detectable concentrations of filtered ammonia, total phosphorous, and filtered zinc (table 6). These detections could be caused by the deionized water not having a specific conductance of less than 1.0 microsiemens per centimeter. Other possible causes are improper cleaning of the equipment, contamination of preservatives used in the samples, and contamination at the laboratory. The source of the blank water for the sample collected and analyzed in August was certified inorganic and organic blank water. This blank water contained detectable concentrations of ammonia and total-recoverable iron.

Standard reference water samples were collected and analyzed during sampling of Clinton and Pomona Lakes to check laboratory analytical accuracy. The most probable values (MPV) for the standard water samples and the analyses are presented in tables 5 and 6. 


\section{REFERENCES CITED}

Anderson, J.R., 1967, Major land uses in the United States, in U.S. Geological Survey, 1970, National atlas of the United States of America: Washington D.C., U.S. Geological Survey, p. 158-159.

Britton, L.J., and Greeson, P.E., eds., 1989, Methods for collection and analysis of aquatic biological and microbiological samples: U.S. Geological Survey Techniques of Water-Resources Investigations, book 5 , chap. A4, $363 \mathrm{p}$.

Buchanan, T.J., and Somers, W.P., 1969, Discharge measurements at gaging stations: U.S. Geological Survey Techniques of Water-Resources Investigations, book 3, chap. A8, 65 p.

Fenneman, N.M., 1946, Physical divisions of the United States: Washington, D.C., U.S. Geological Survey special map, scale 1:7,000,000.

Fischer, E.E., Melcher, N.B., and Kluesner, S.P., 1990, Statistical summaries of selected Iowa streamflow data through September 30, 1988: U.S. Geological Survey Open-File Report 90-170, 639 p.

Fishman, M.J., ed., 1993, Methods of analysis by the U.S. Geological Survey National Water Quality Laboratory-Determination of inorganic and organic constituents in water and fluvial sediments: U.S. Geological Survey Open-File Report 93-125, 217 p.

Fịshman, M.J., and Friedman, L.C., eds., 1989, Methods for determination of inorganic substances in water and fluvial sediments: U.S. Geological Survey Techniques of Water-Resources Investigations, book 5, chap. A1, $545 \mathrm{p}$.

National Oceanic and Atmospheric Administration, 1951-80, Monthly normals of temperature, precipitation, and heating and cooling degree days, Iowa, Kansas, Nebraska: Asheville, North Carolina.

Patton, C.J., and Truit, E.P., 1992, Methods of analysis by the U.S. Geological Survey National Water Quality Laboratory-Determination of total phosphorus by a Kjeldahl digestion method and an automated colori- metric finish that includes dialysis: U.S. Geological Survey Open-File Report 92-146, 39 p.

Pomes, M.L., and Thurman, E.M., 1991, Comparison of microtitre-plate immunoassay (ELISA) and gas chromatography/mass spectrometry (GC/MS) for analysis of herbicides in storm-runoff samples: U.S. Geological Survey Water-Resources Investigations Report 91-4034, p. 572-575.

Prior, J.C., 1991, Landforms of Iowa: Iowa City, University of Iowa Press, $153 \mathrm{p}$.

Southard, R.E., Sneck Fahrer, Debra, Anderson, C.J., Goodrich, R.D., and Gorman, J.G., 1994, Water resources data, Iowa, water year 1993: U.S. Geological Survey Water-Data Report IA-93-1, 388 p.

Thurman, E.M., Meyer, M.T., Pomes, M.L., Perry, C.A., and Schwab, A.P., 1990, Enzyme-linked immunosorbent assay compared with gas chromatography/ mass spectrometry for the determination of triazine herbicides in water: Analytical Chemistry, v. 62, no. 18, p. 2043-2048.

U.S. Environmental Protection Agency, 1993, Drinking water regulations and health advisories: Washington, D.C., U.S. Environmental Protection Agency, Office of Water, December, $14 \mathrm{p}$.

U.S. Geological Survey, 1986, National water summary 1985-Hydrologic events and surface-water resources: U.S. Geological Survey Water-Supply Paper 2300, $506 \mathrm{p}$.

Ward, J.R., and Harr, C.A., 1990, Methods for collection and processing of surface-water and bed-material samples for physical and chemical analyses: U.S. Geological Survey Open-File Report 90-190, 71 p.

Wells, F.C., Gibbons, W.J., and Dorsey, M.E., 1990, Guidelines for collection and field analysis of water-quality samples from streams in Texas: U.S. Geological Survey Open-File Report 90-127, 79 p.

Wershaw, R.L., Fishman, M.J., Grabbe, R.R., and Lowe, L.E., eds., 1987, Methods for determination of organic substances in water and fluvial sediments: U.S. Geological Survey Techniques of Water-Resources Investigations, book 5, chap. A3, $80 \mathrm{p}$. 


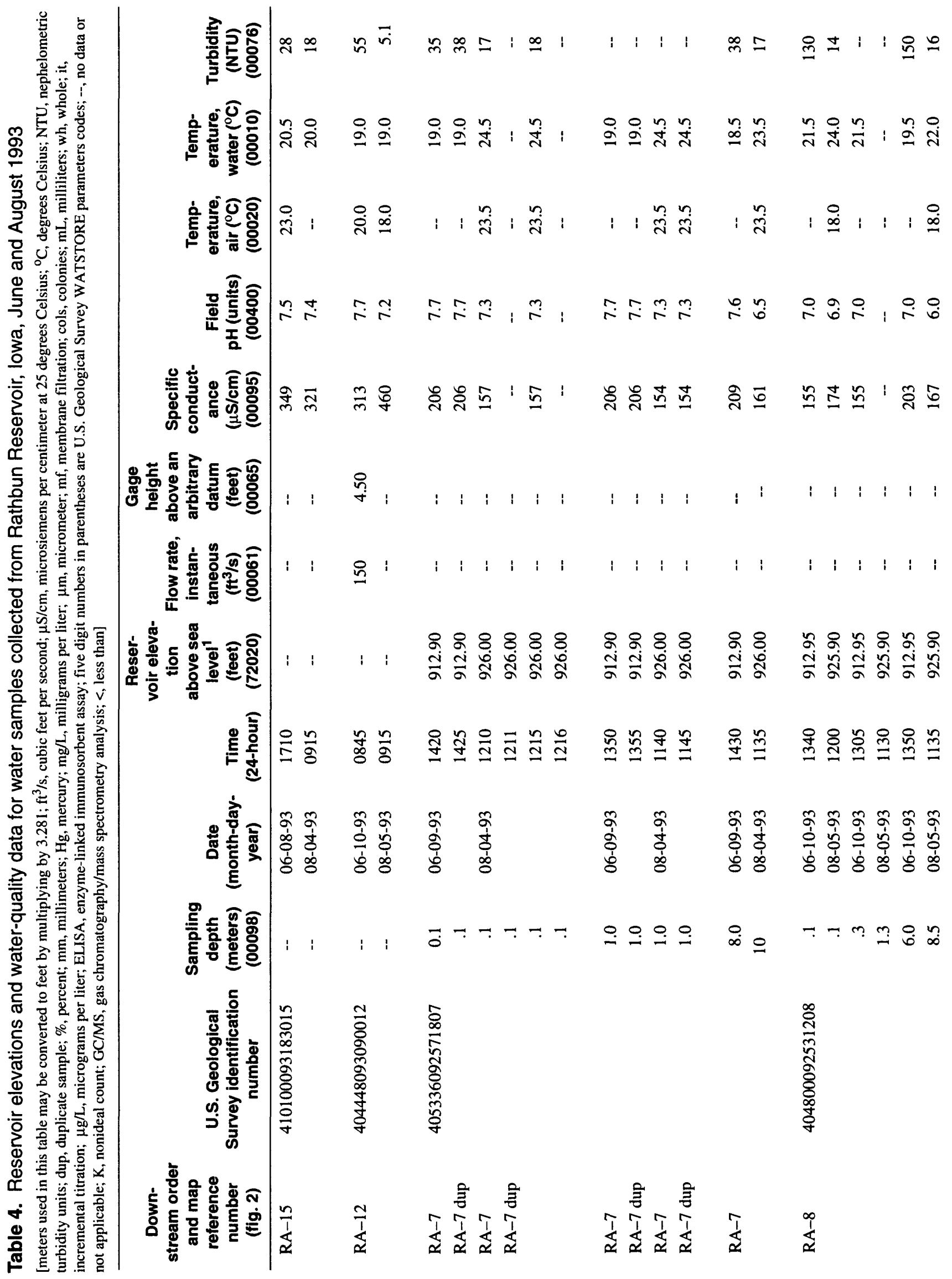

20 Water-Quality Conditions of Inflow, Outflow, and Impounded Water at Rathbun Reservoir, lowa, Clinton and Pomona Lakes, Kansas, and Harlan County Reservoir, Nebraska, May Through August 1993 


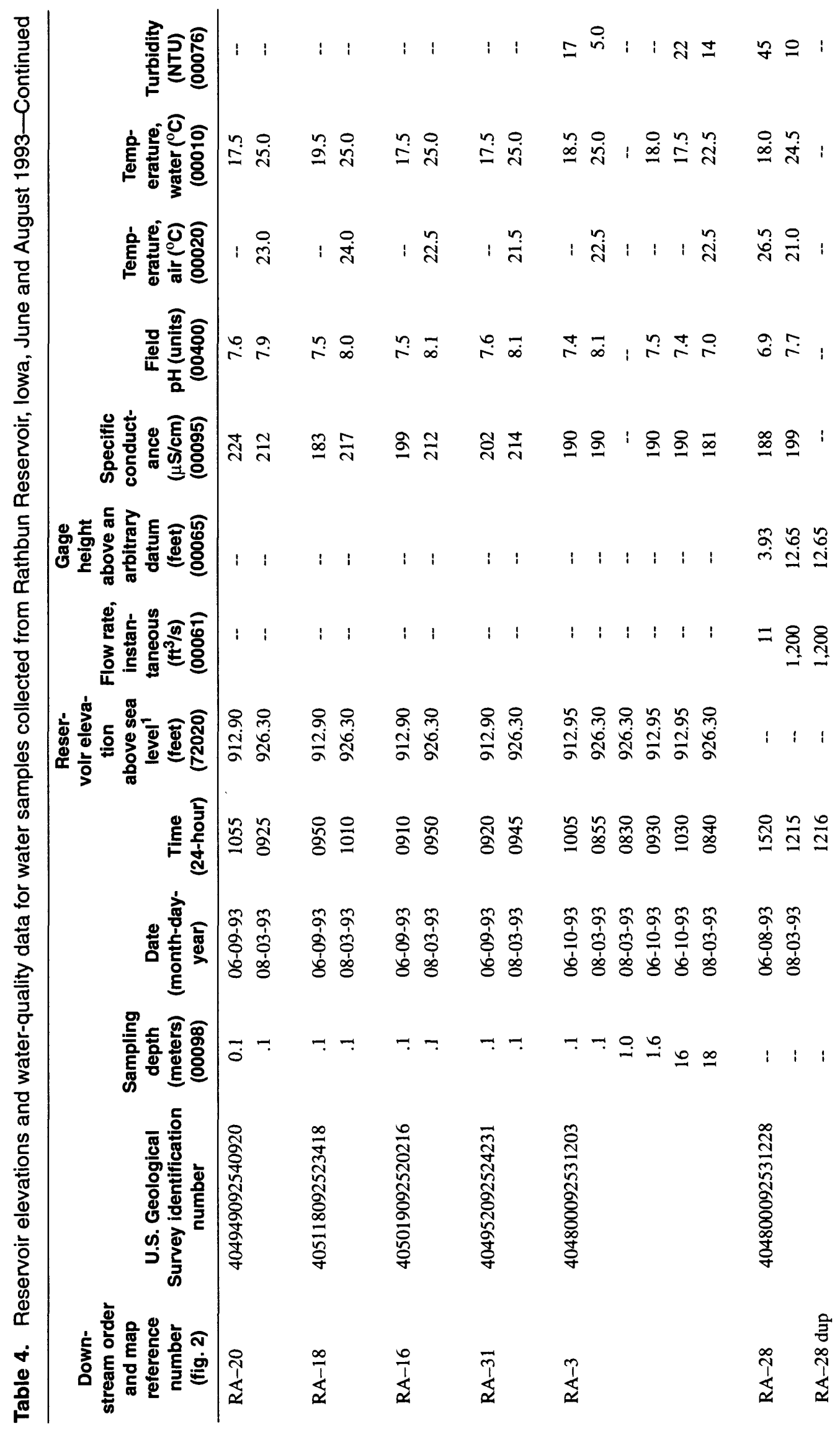




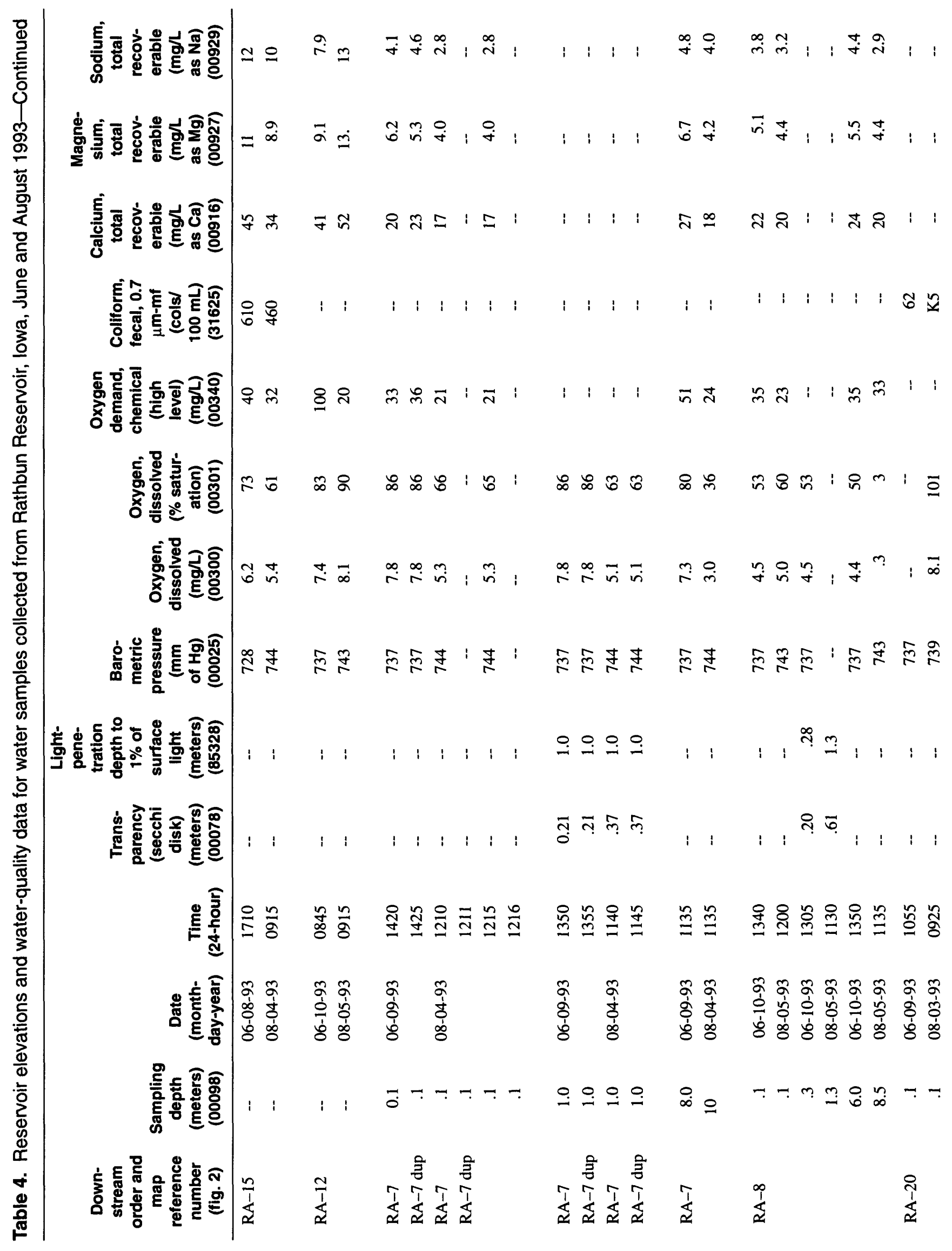




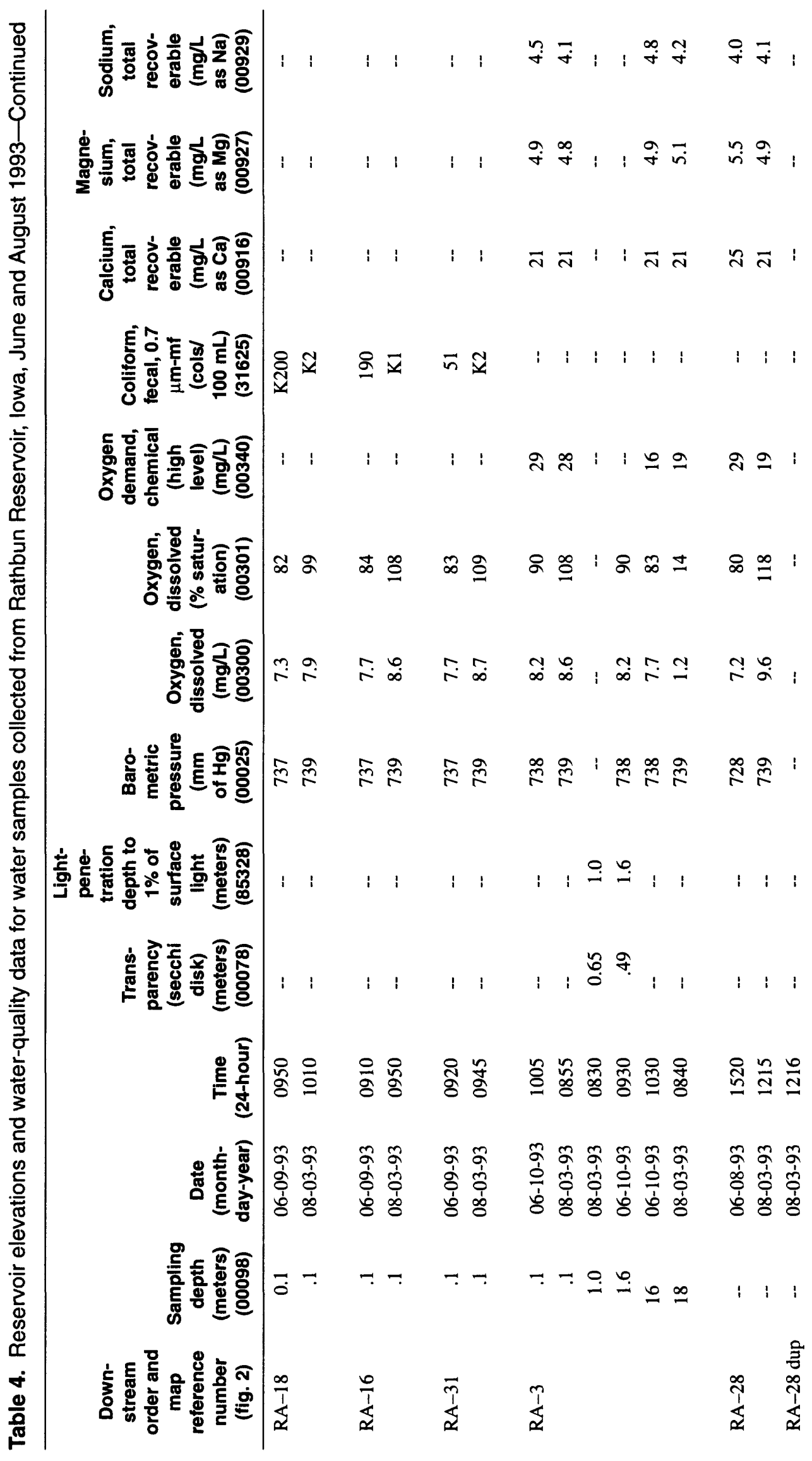




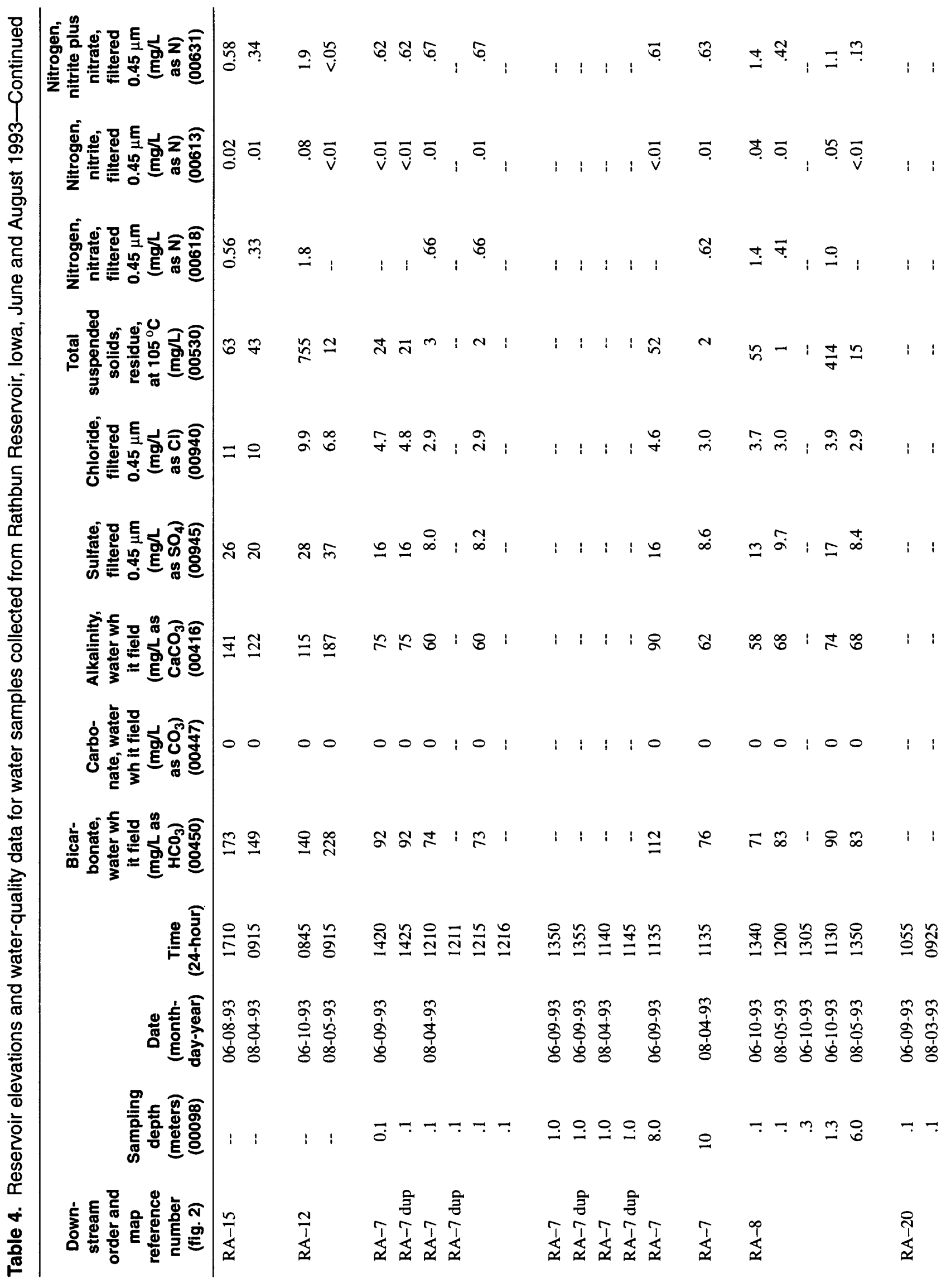




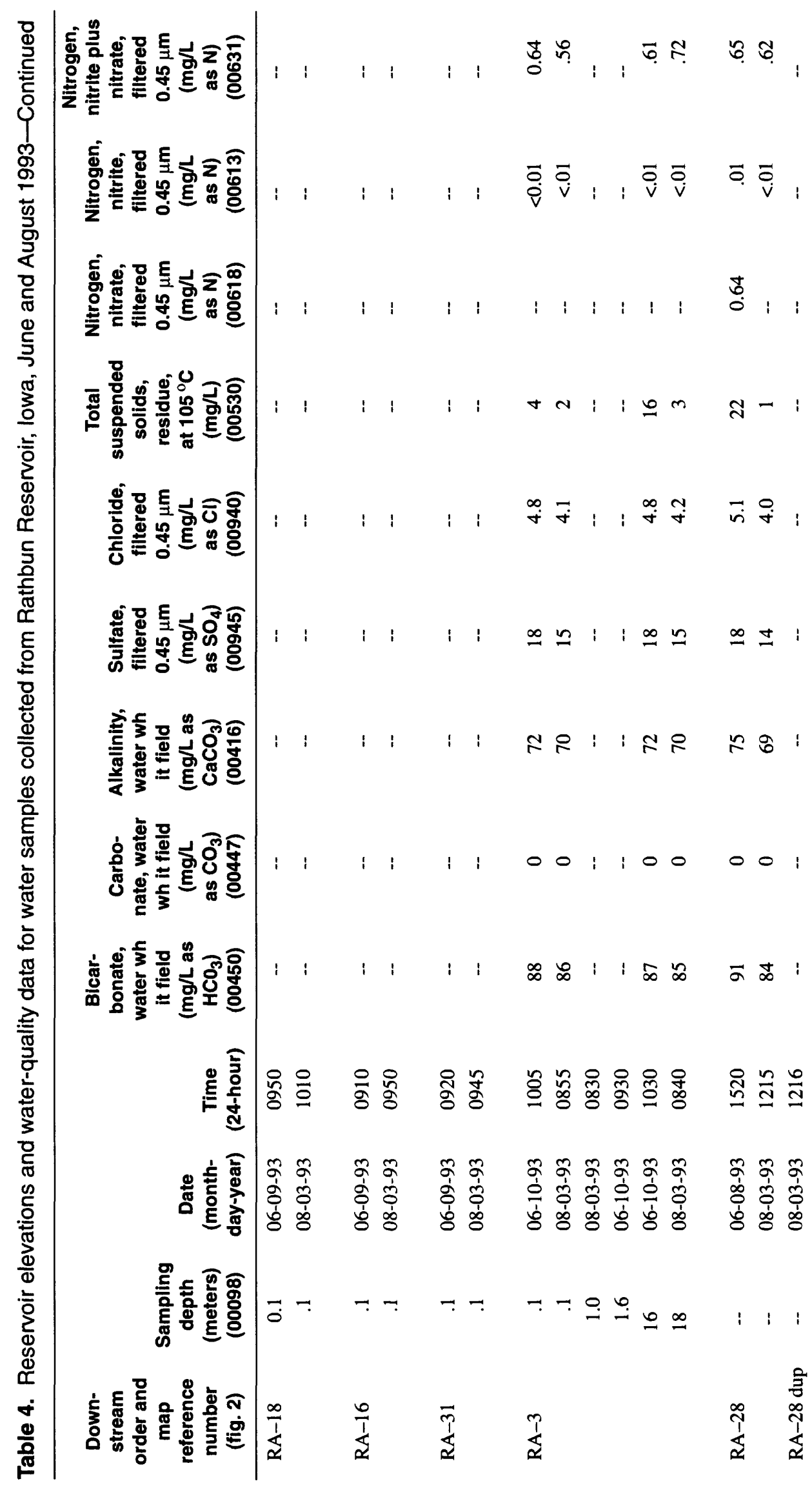




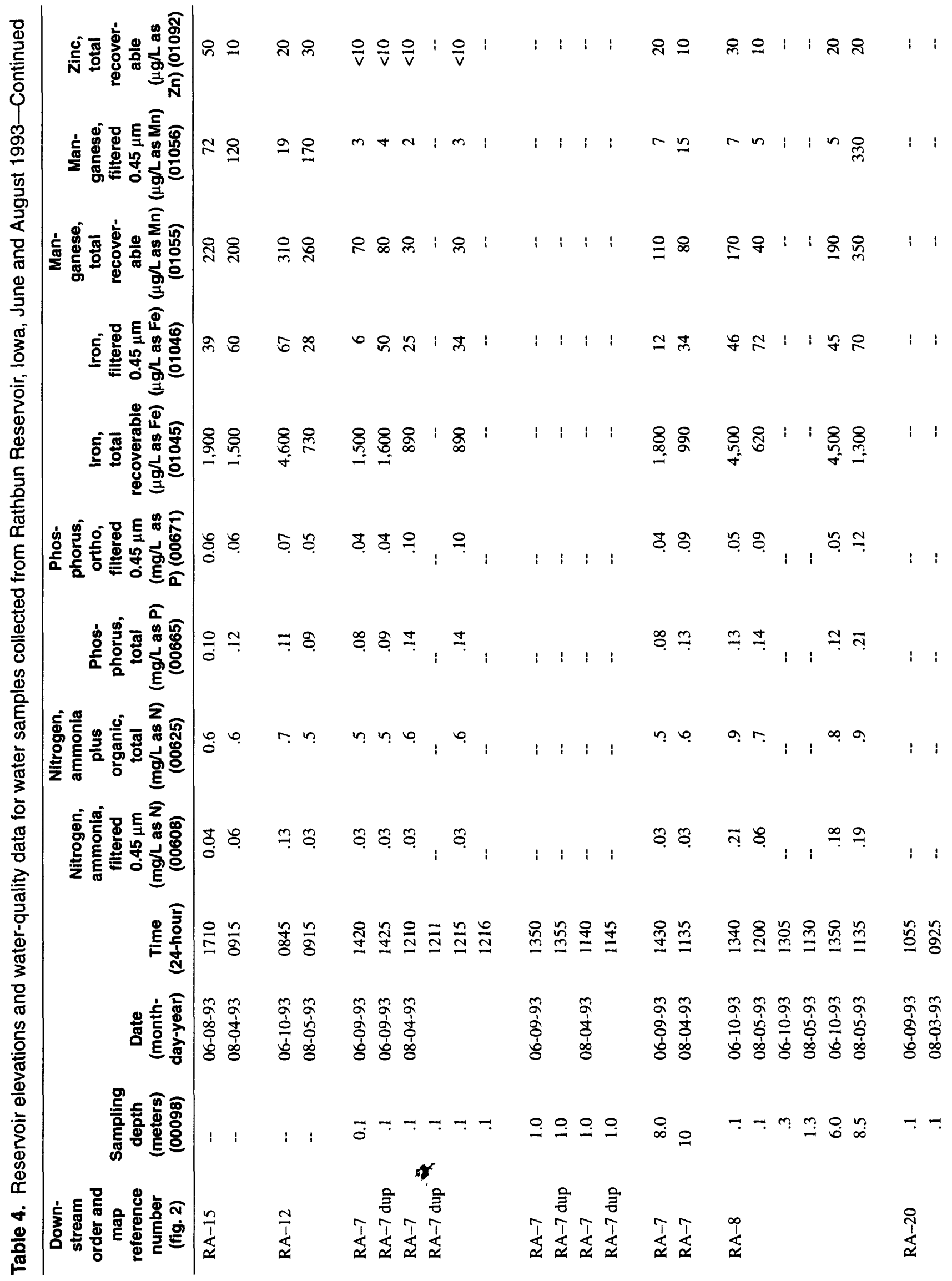




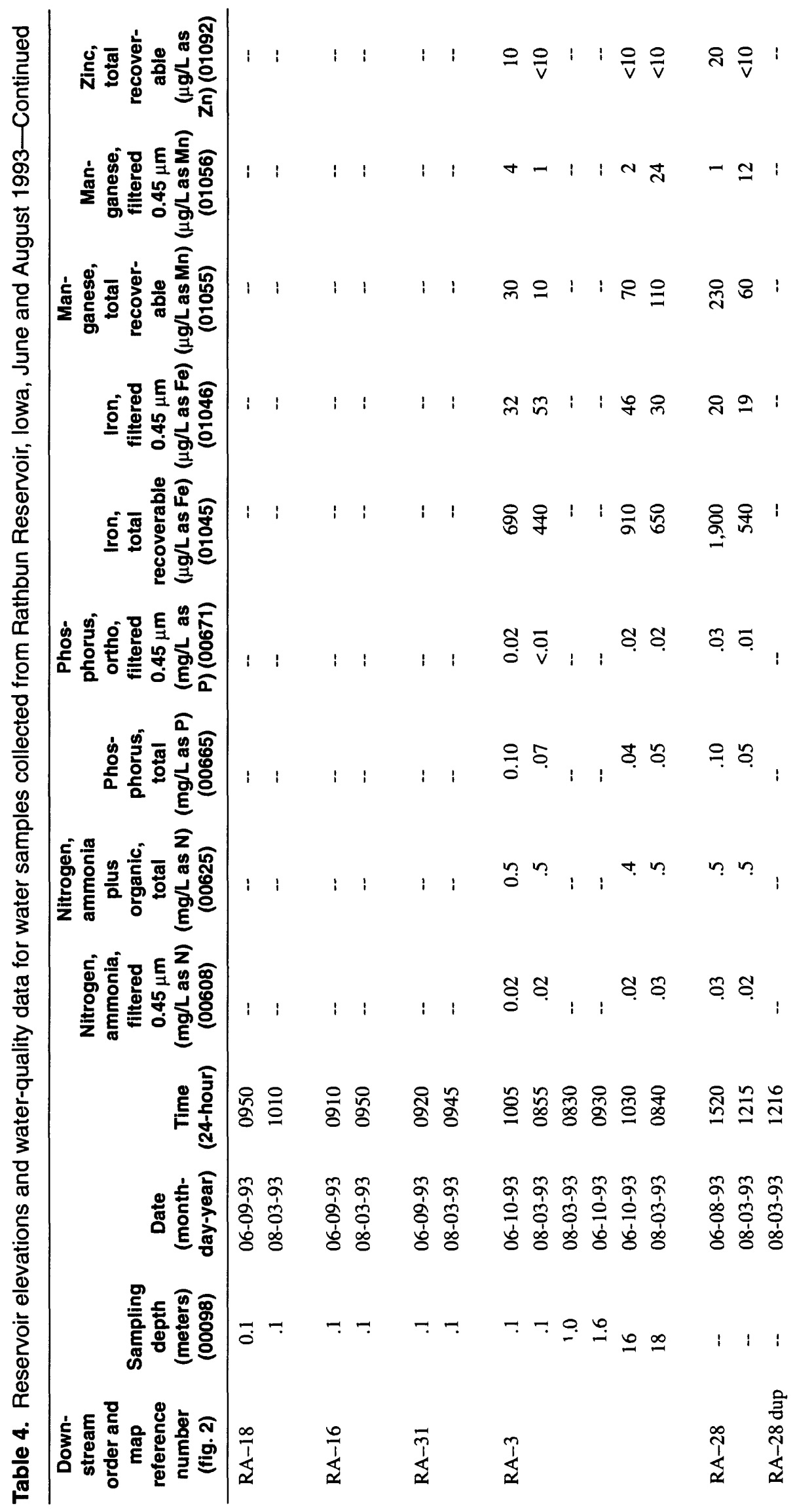




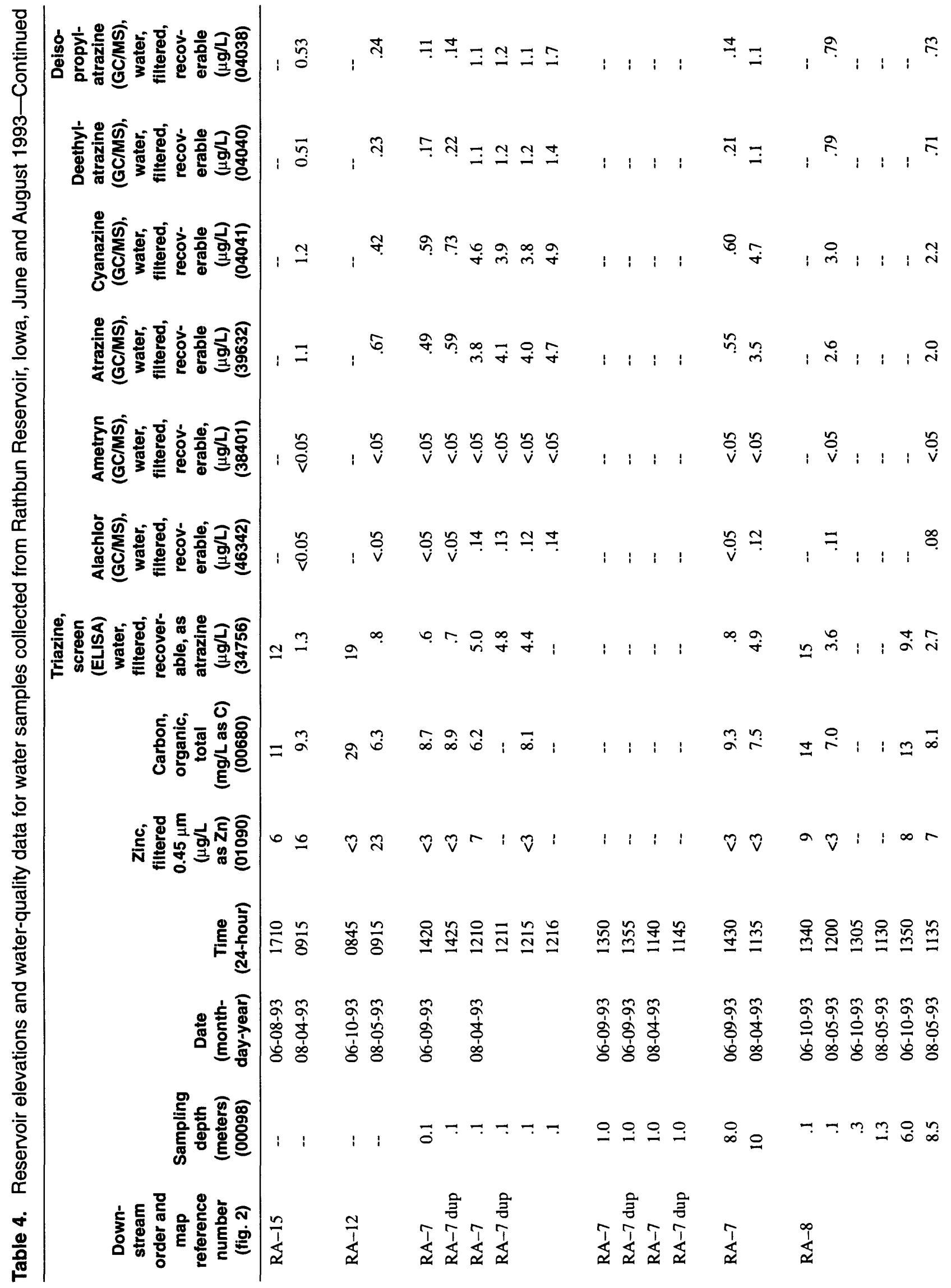

28 Water-Quality Conditions of Inflow, Outflow, and Impounded Water at Rathbun Reservoir, lowa, Clinton and Pomona Lakes, Kansas, and Harlan County Reservoir, Nebraska, May Through August 1993 


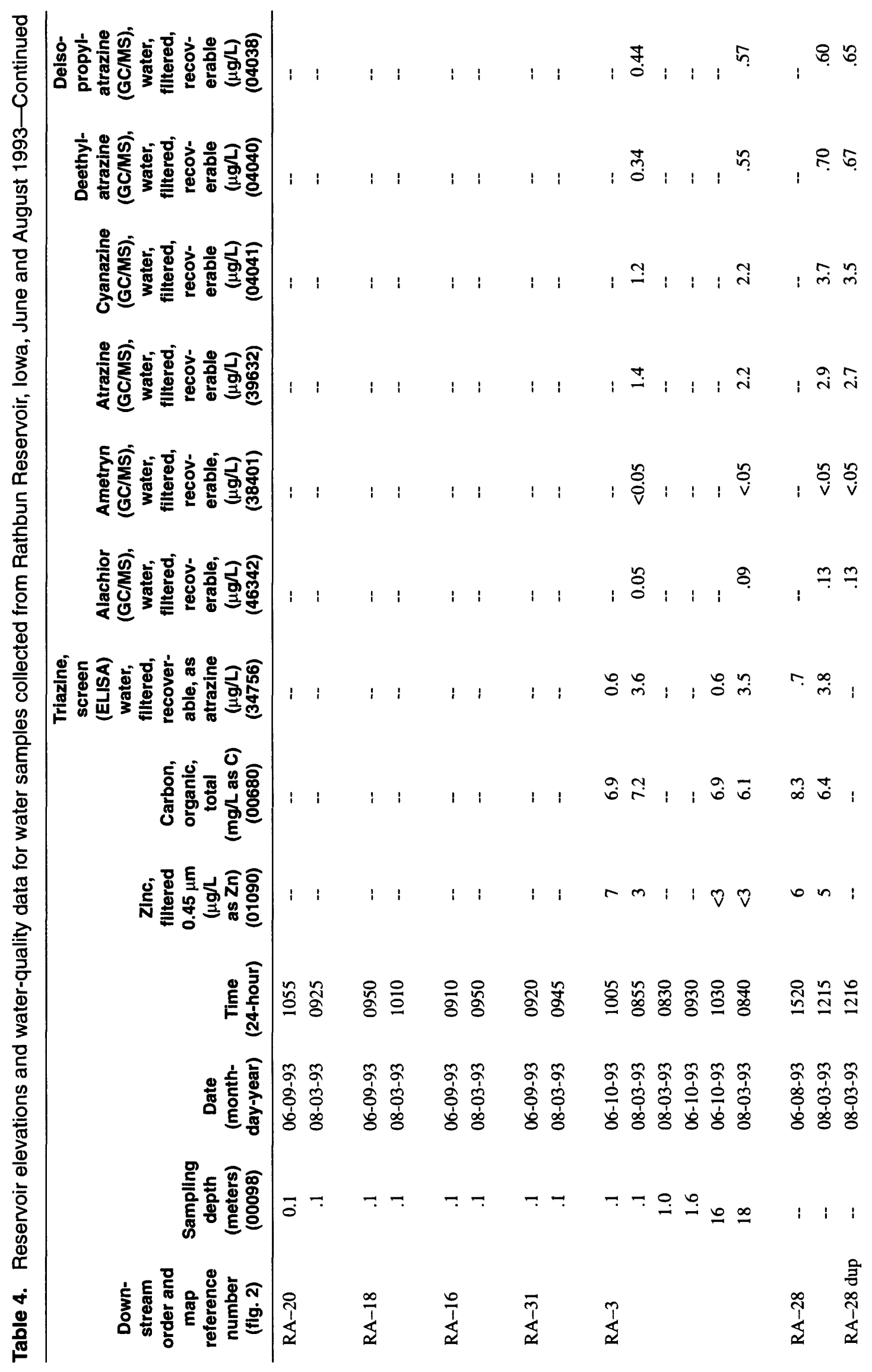




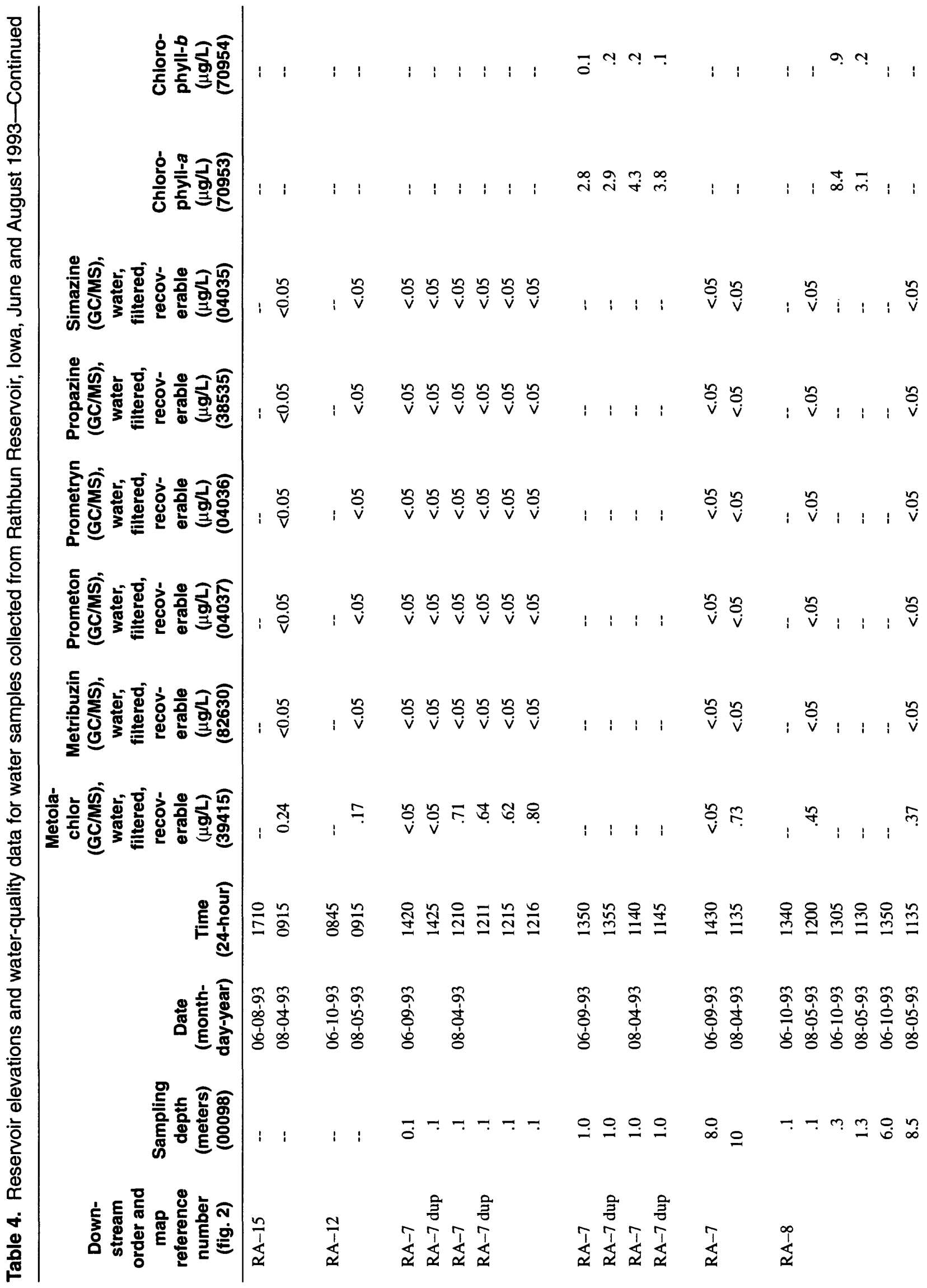




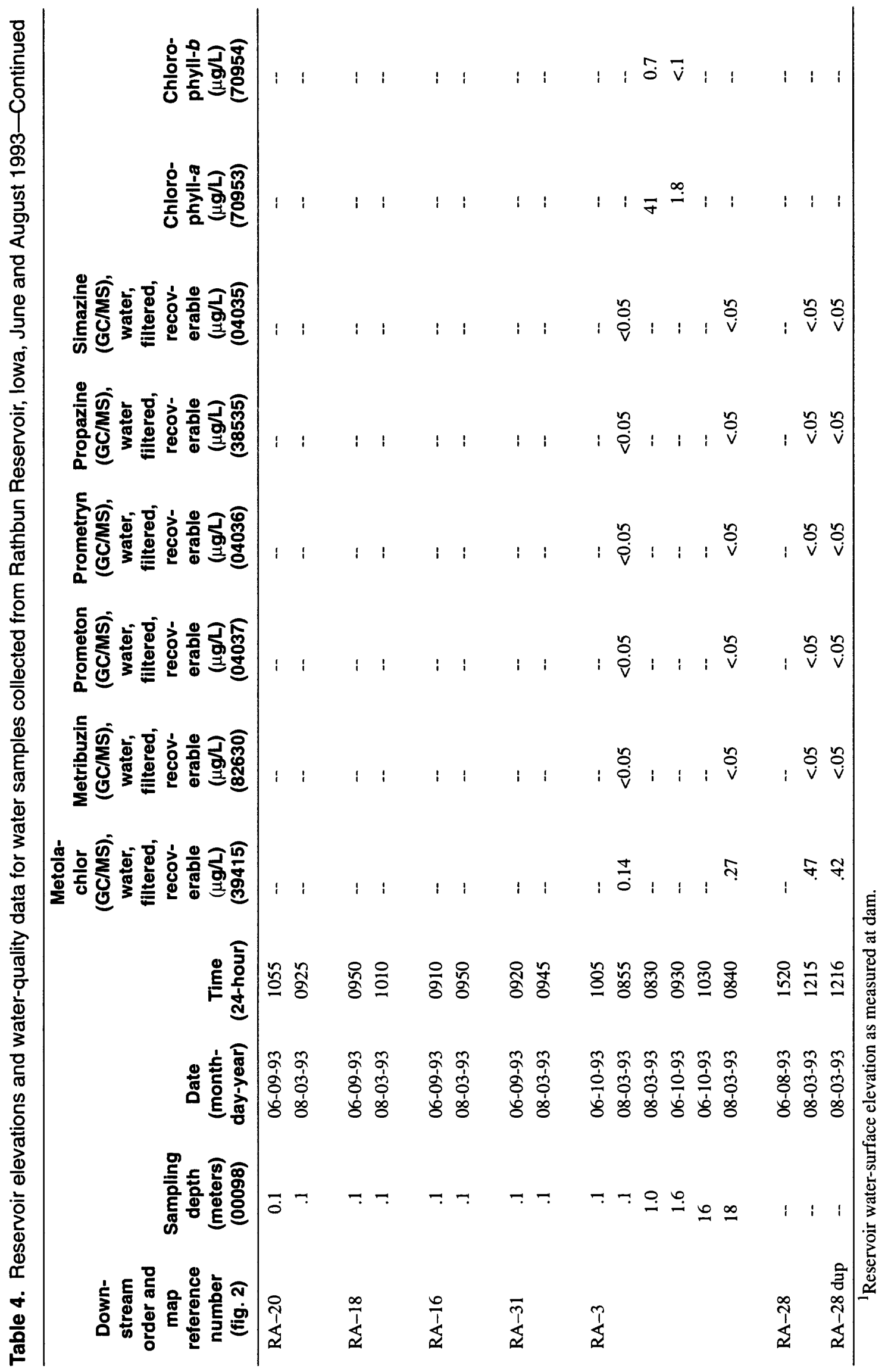




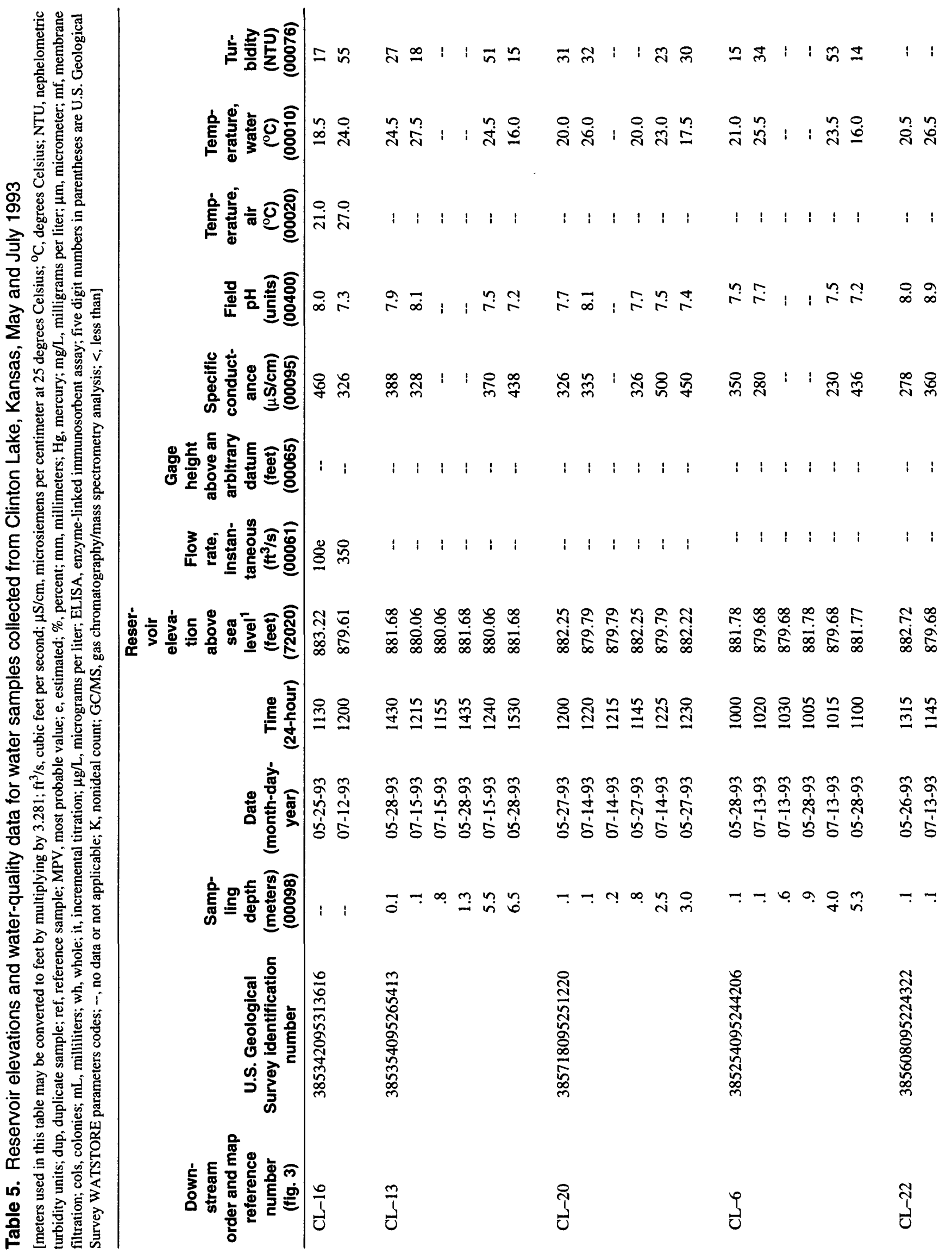




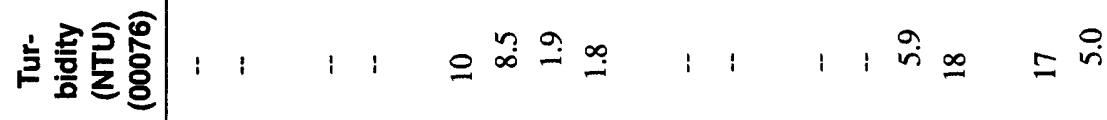

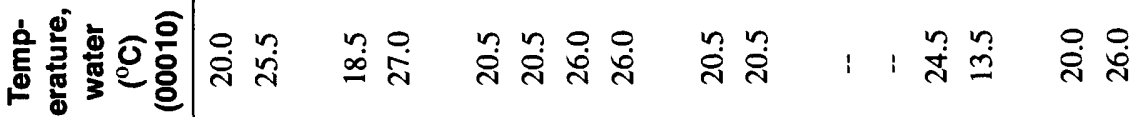

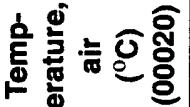

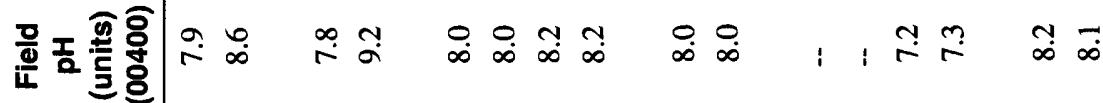

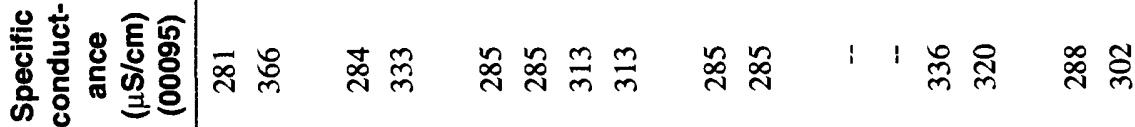

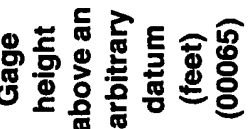

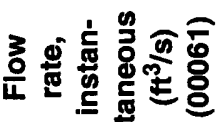

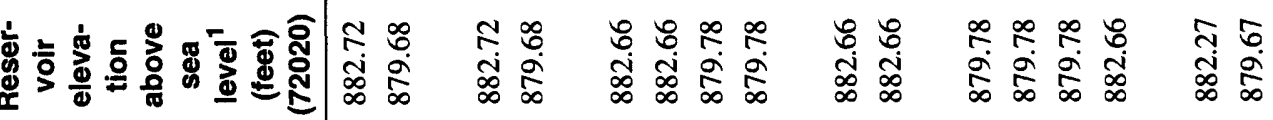

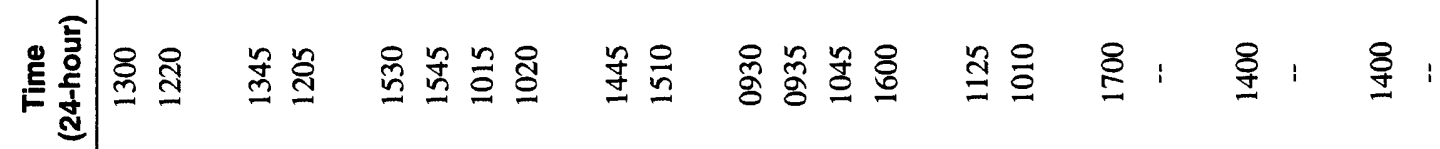

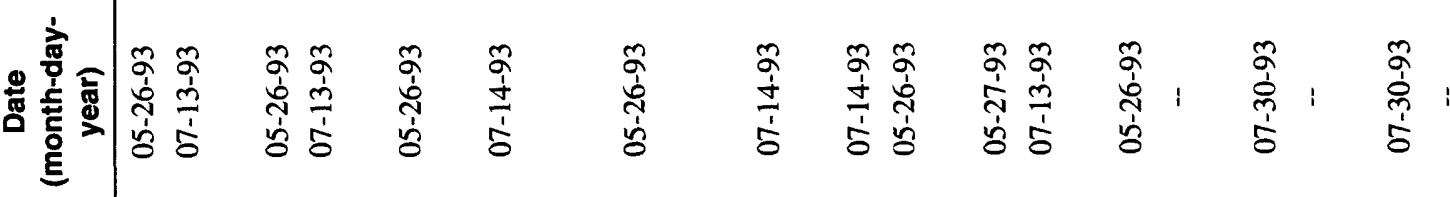

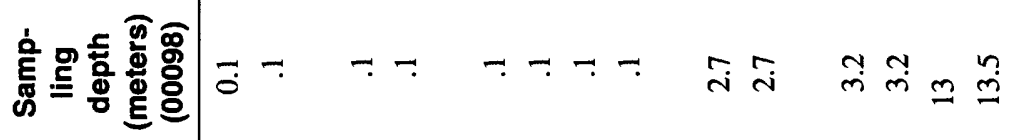

\begin{tabular}{|c|c|c|c|c|c|c|}
\hline 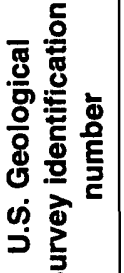 & 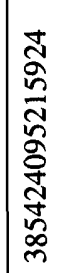 & 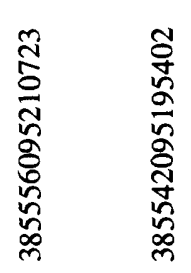 & 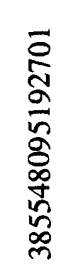 & 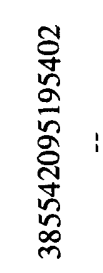 & & 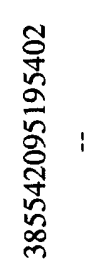 \\
\hline
\end{tabular}

$\check{\simeq}$

㝕

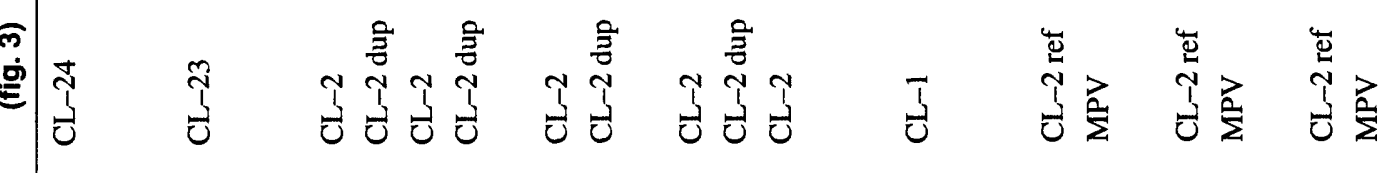




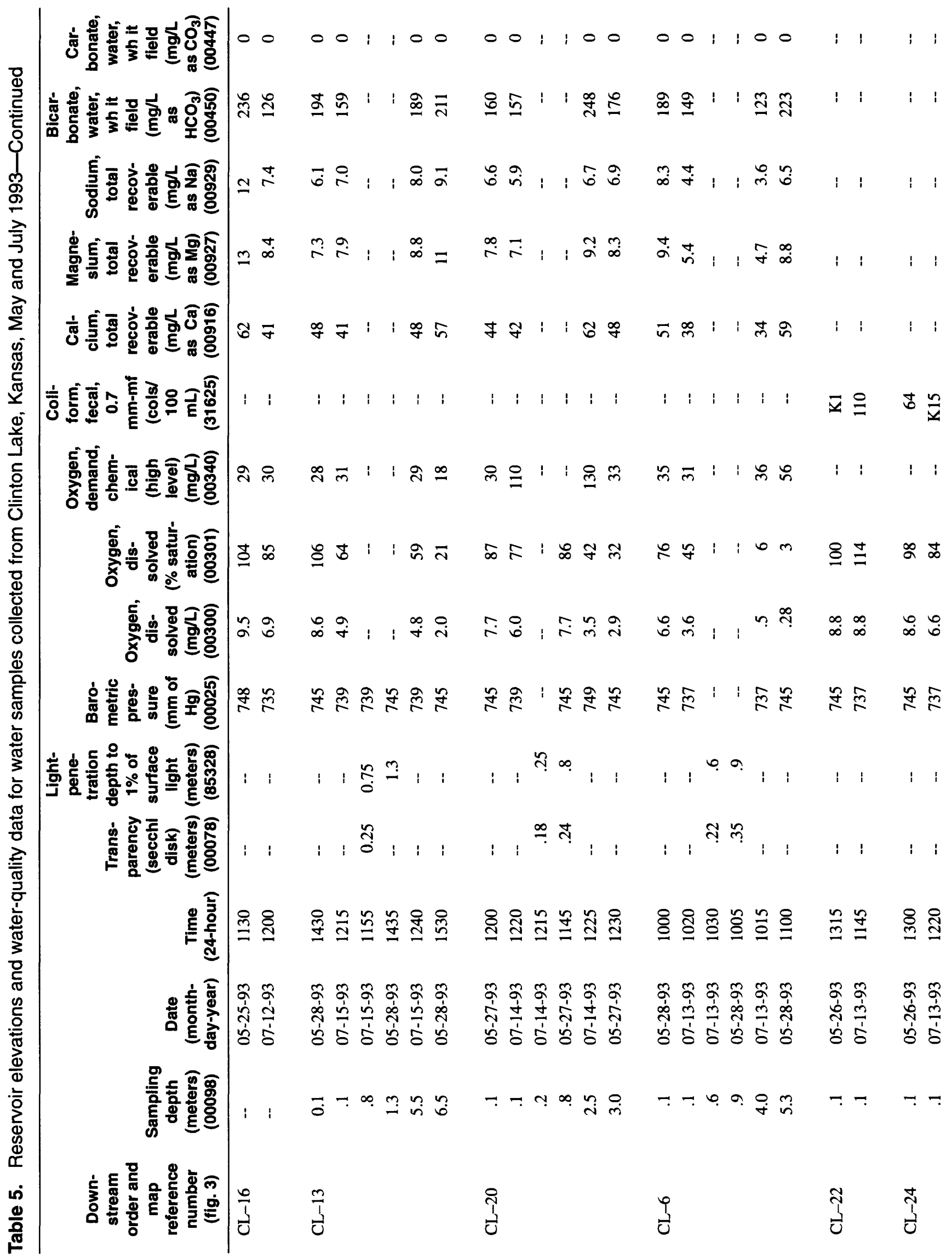




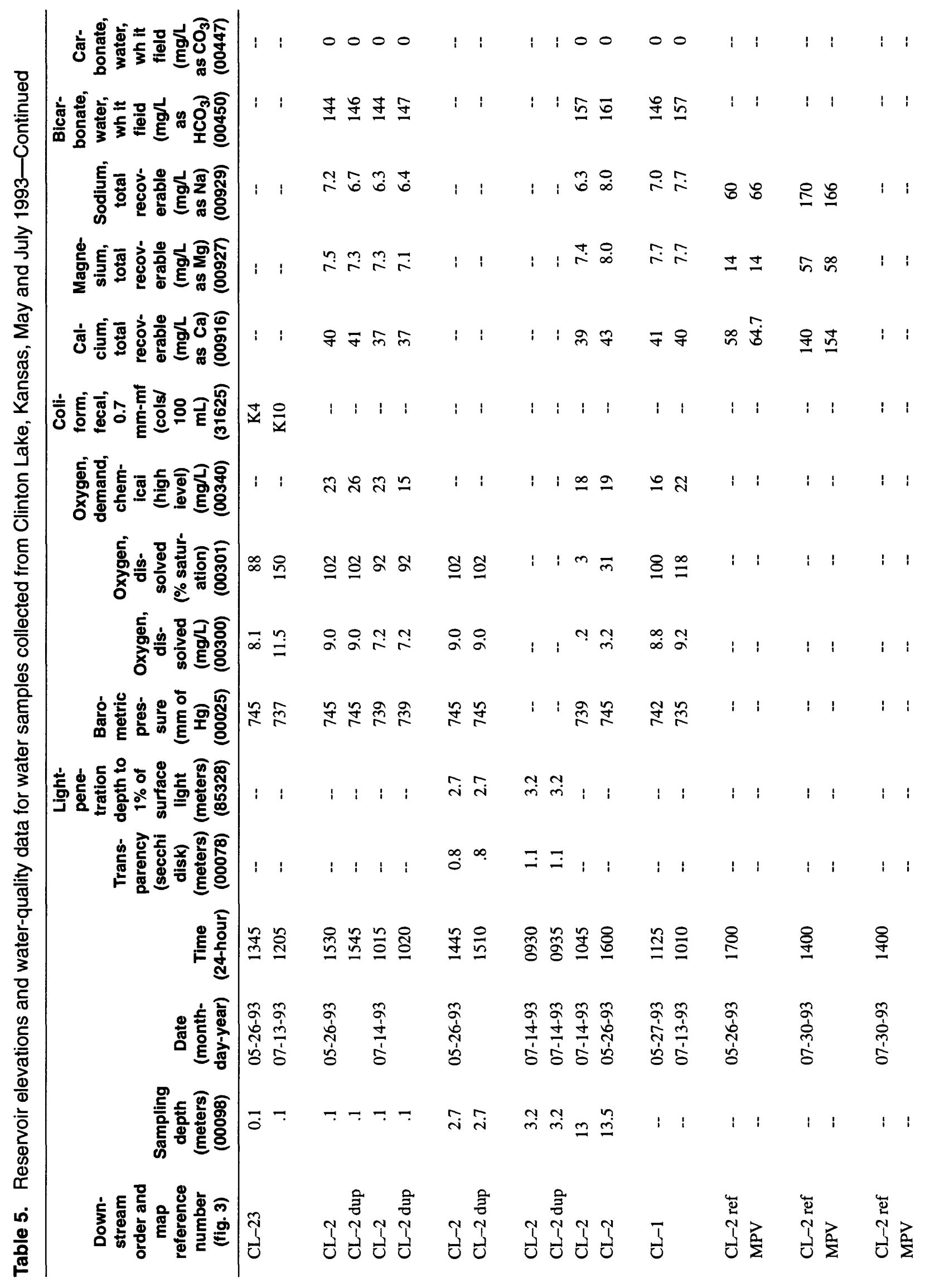




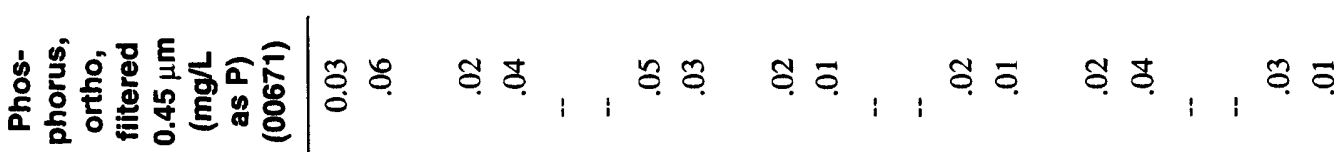

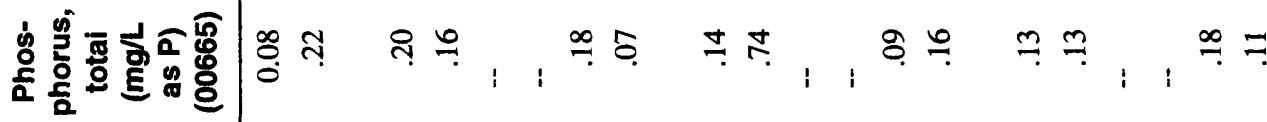

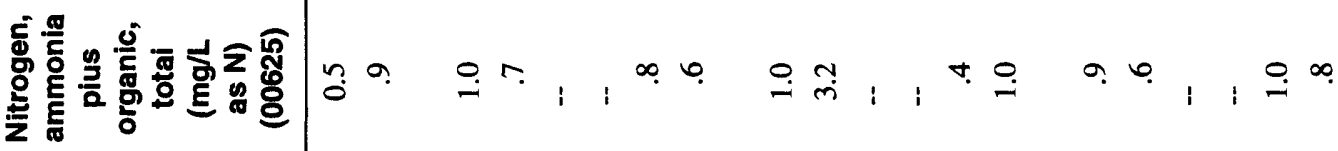

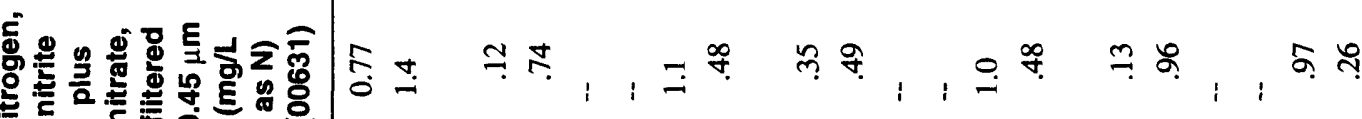
बूँ

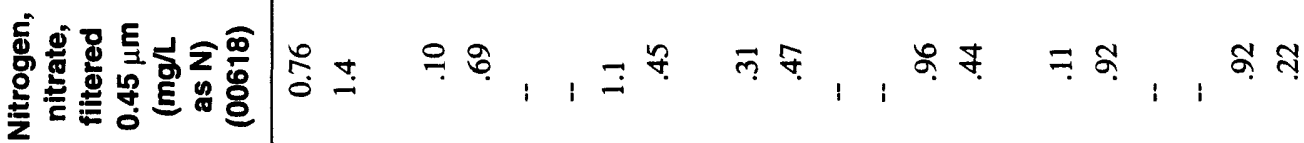

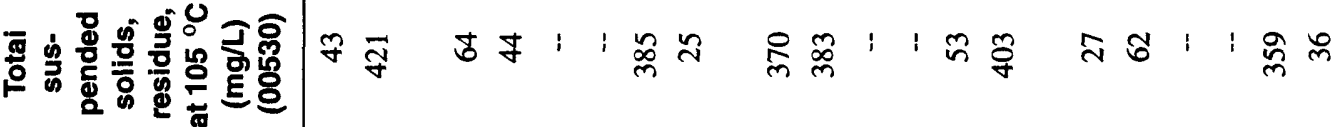

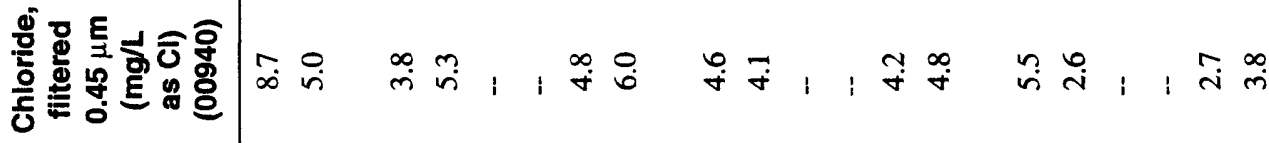

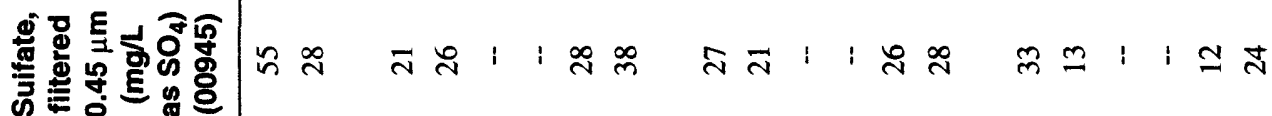

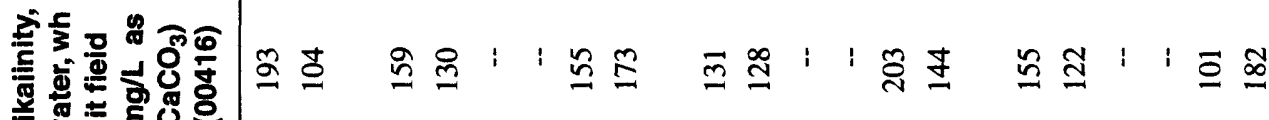

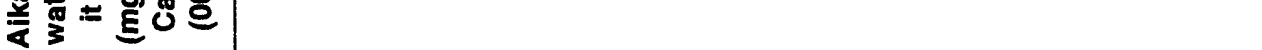

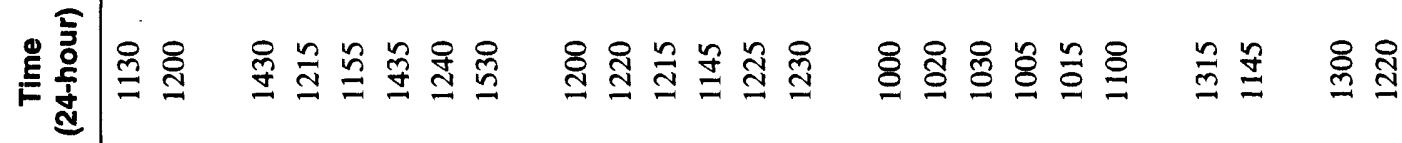

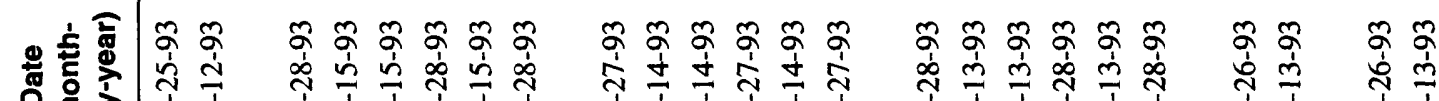

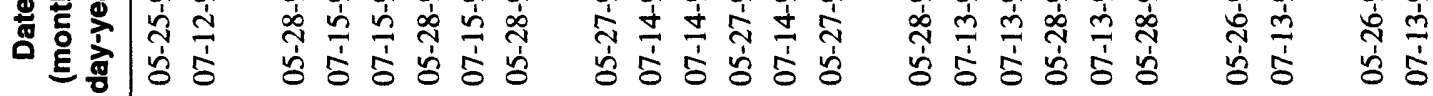

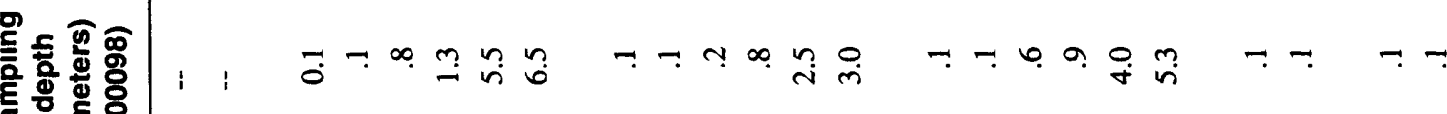
㝏

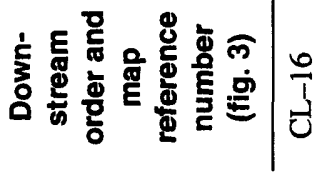

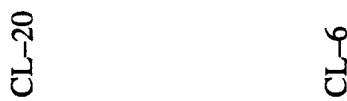<smiles>[O][Al]O</smiles> 


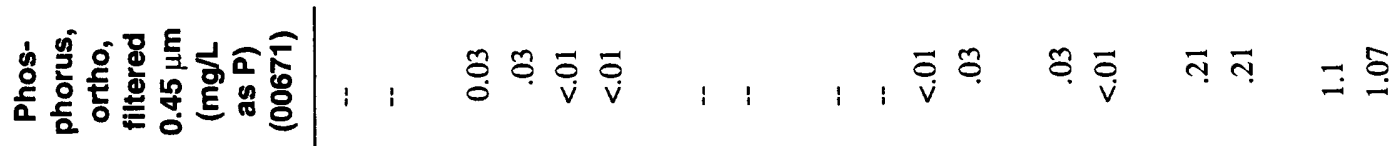

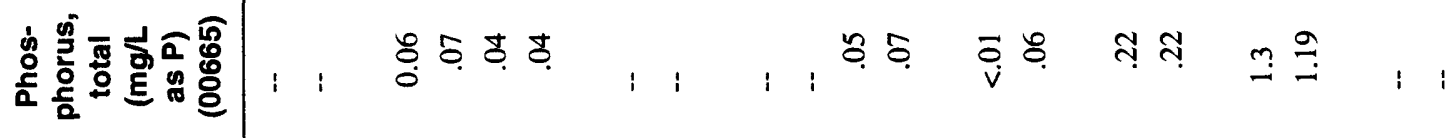

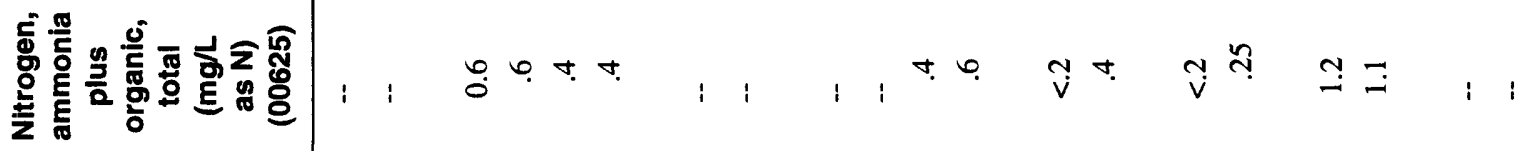

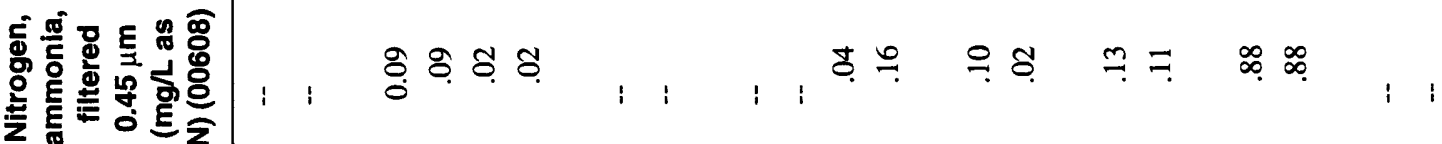

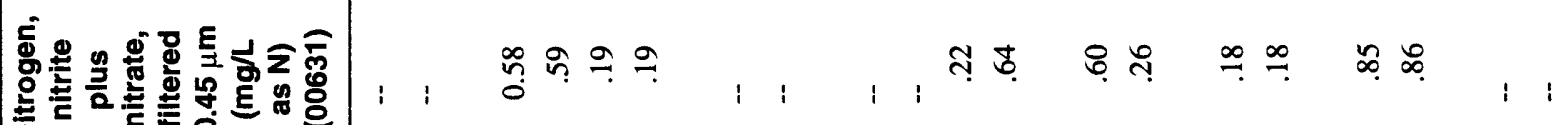

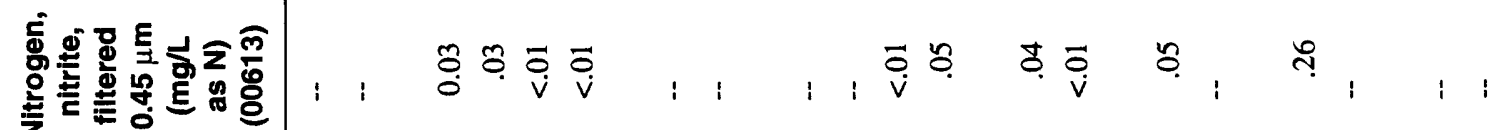

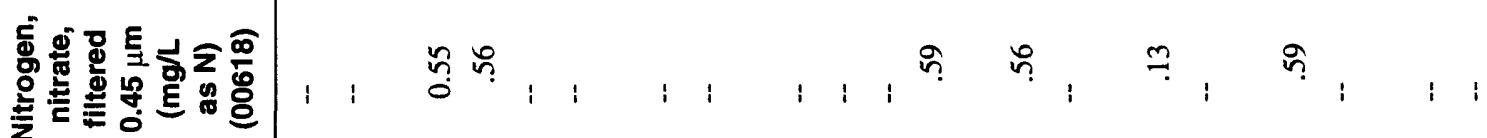

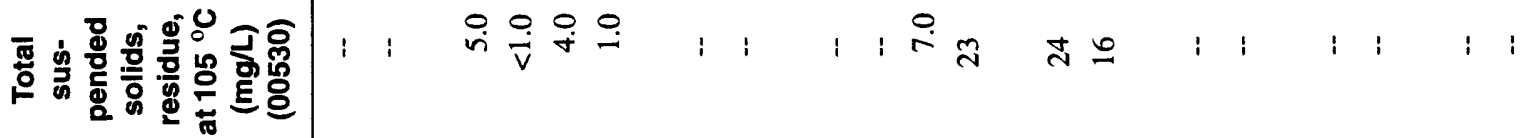

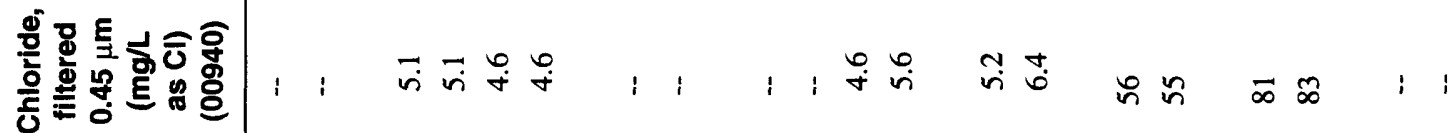

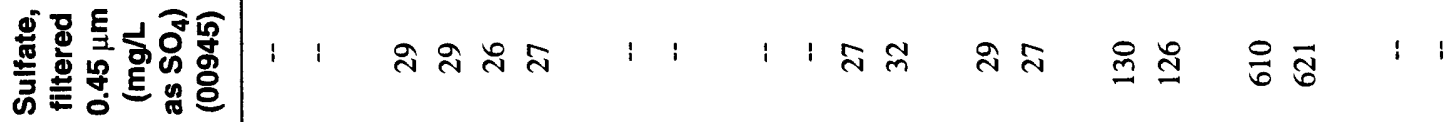

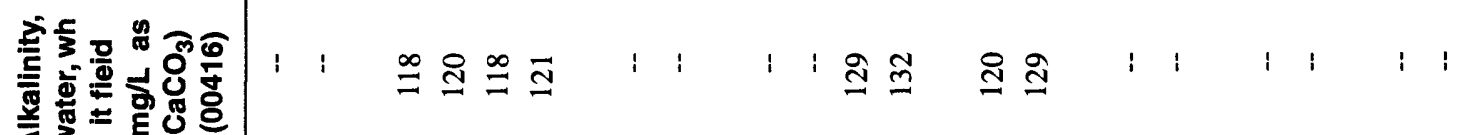

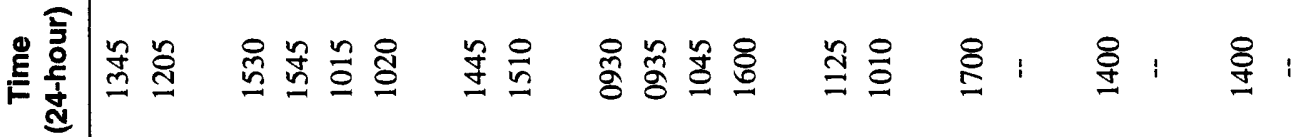

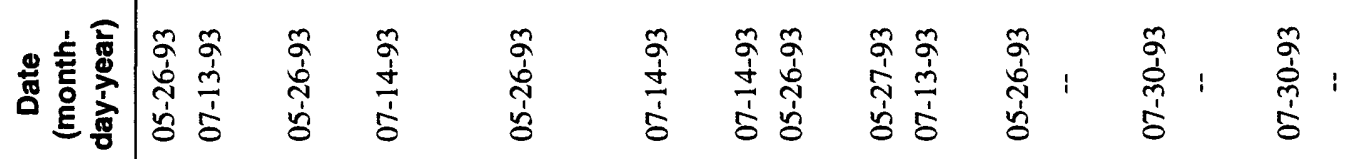

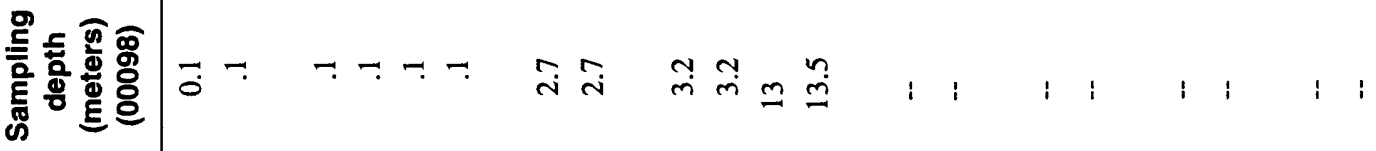

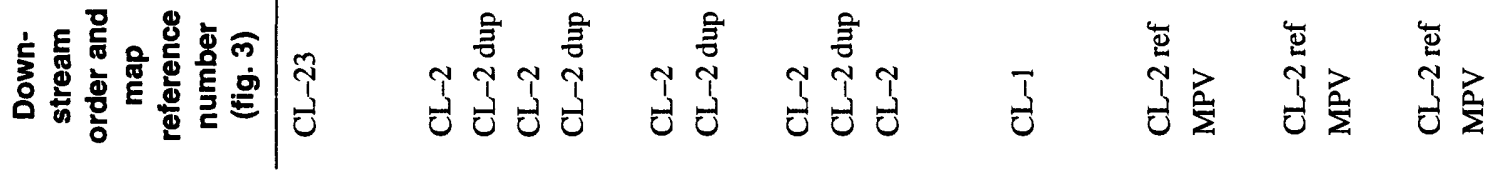




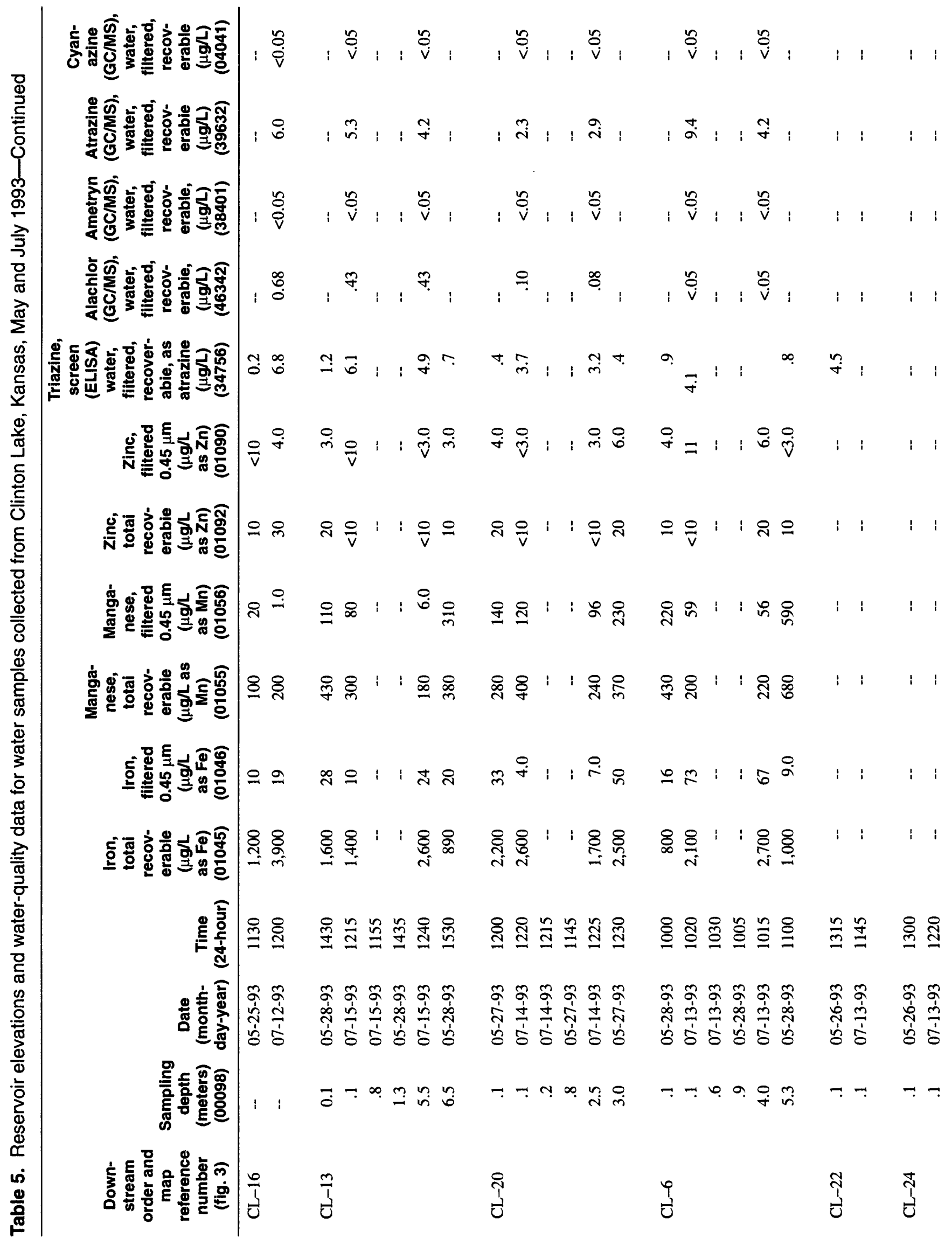




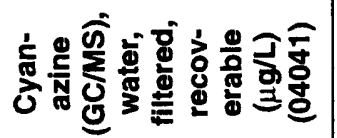

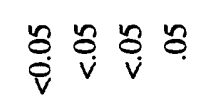

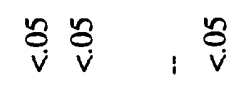

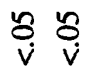

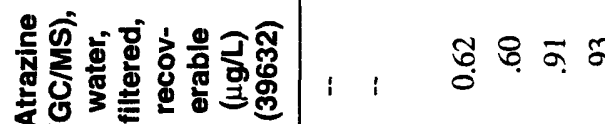
ơ

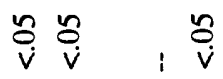
97

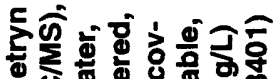
过范要

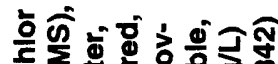
过罗焉

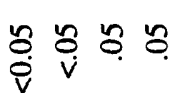
๖ุ ĭ

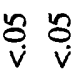

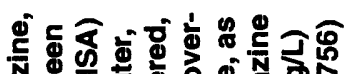

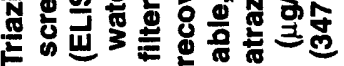

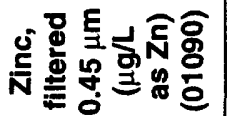
$1 \quad \frac{O}{v} \stackrel{0}{v} \stackrel{0}{v} \stackrel{v}{v}$

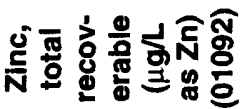
i i $\varrho \varrho \frac{\mathrm{V}}{\mathrm{v}}$ $\stackrel{\circ}{v}$ 오 은

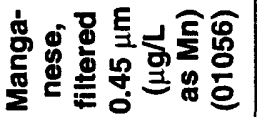

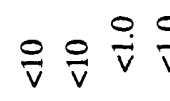
$\infty$ 유유 유 융 总卷 유 유 앙 옹요 $ㅇ$ 이 $\quad \stackrel{\circ}{V}:$

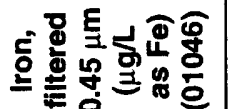

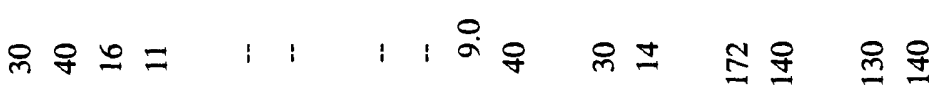

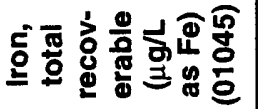
악융익 i

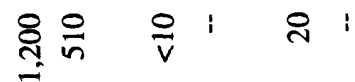
点亭

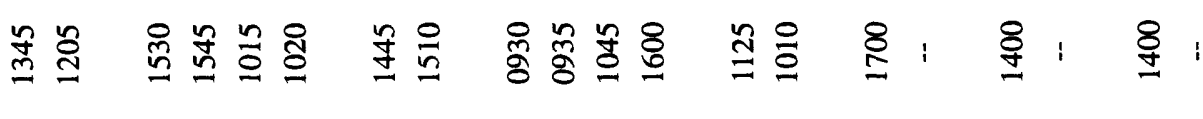

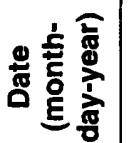
ڤิ̀े

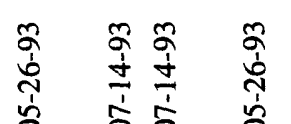

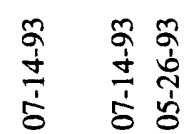

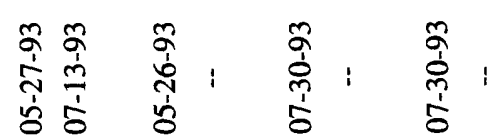

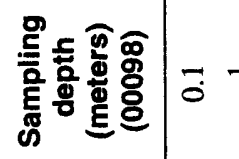
ำ

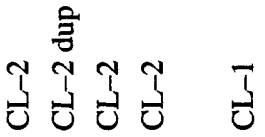

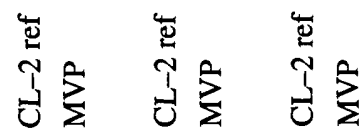




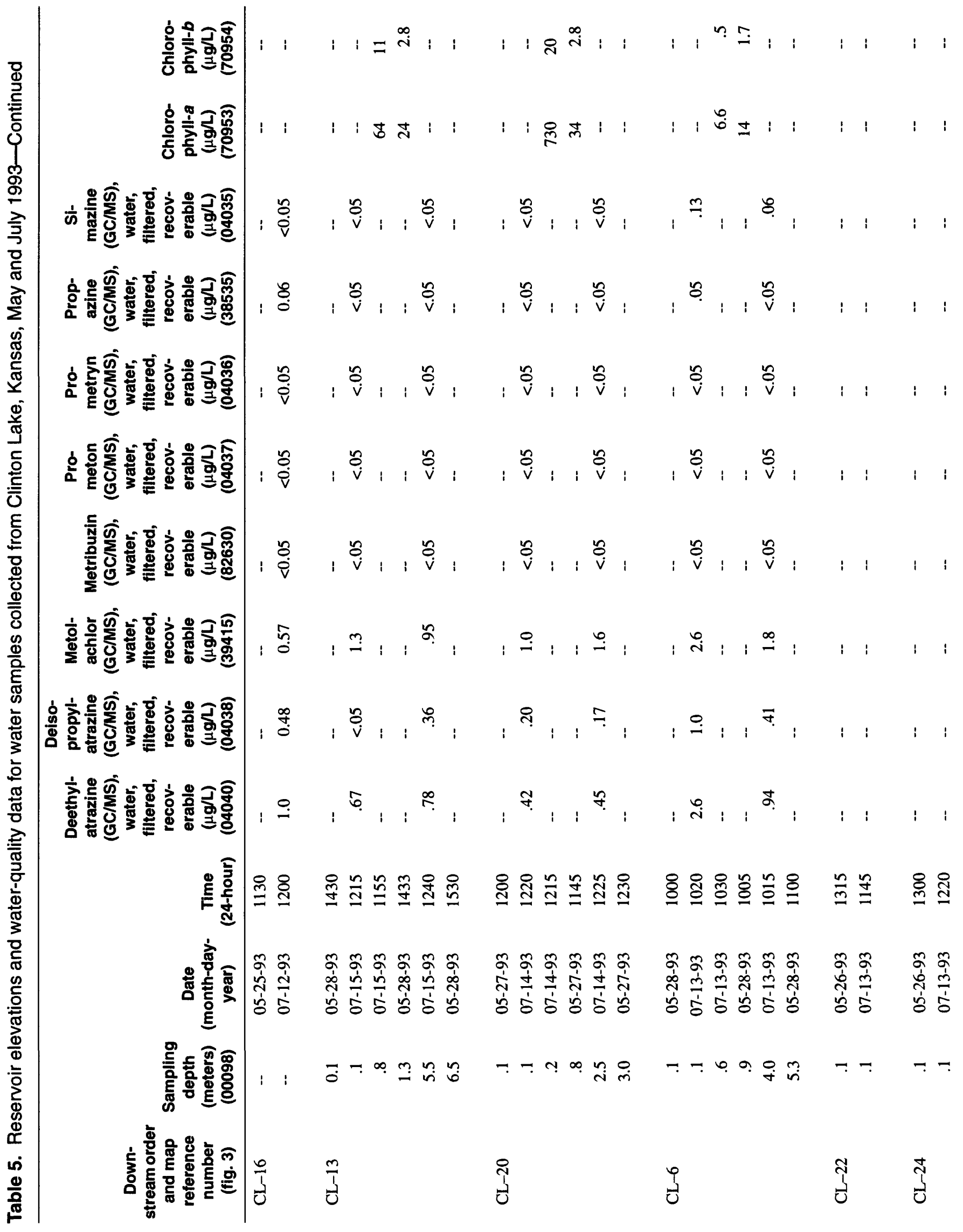




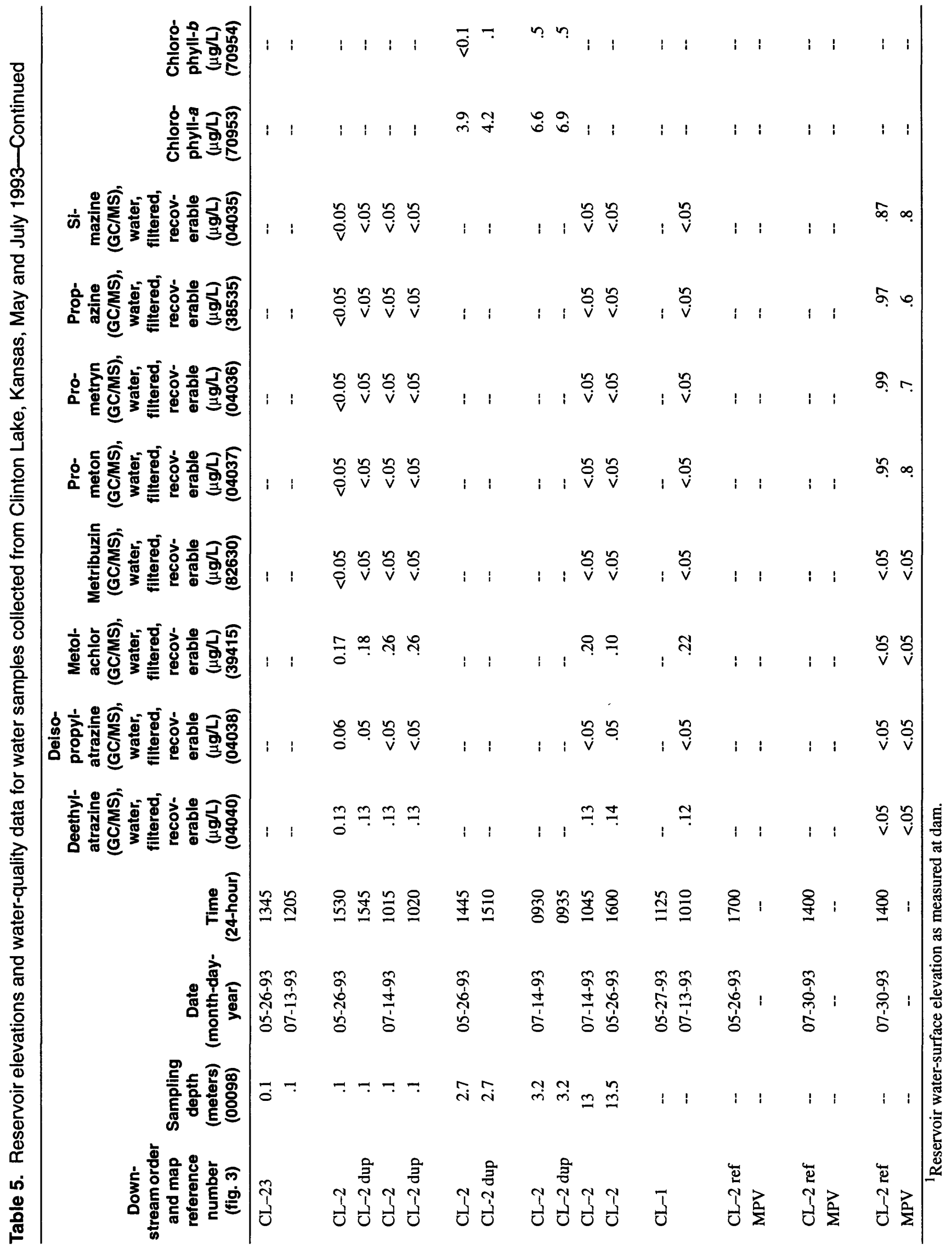




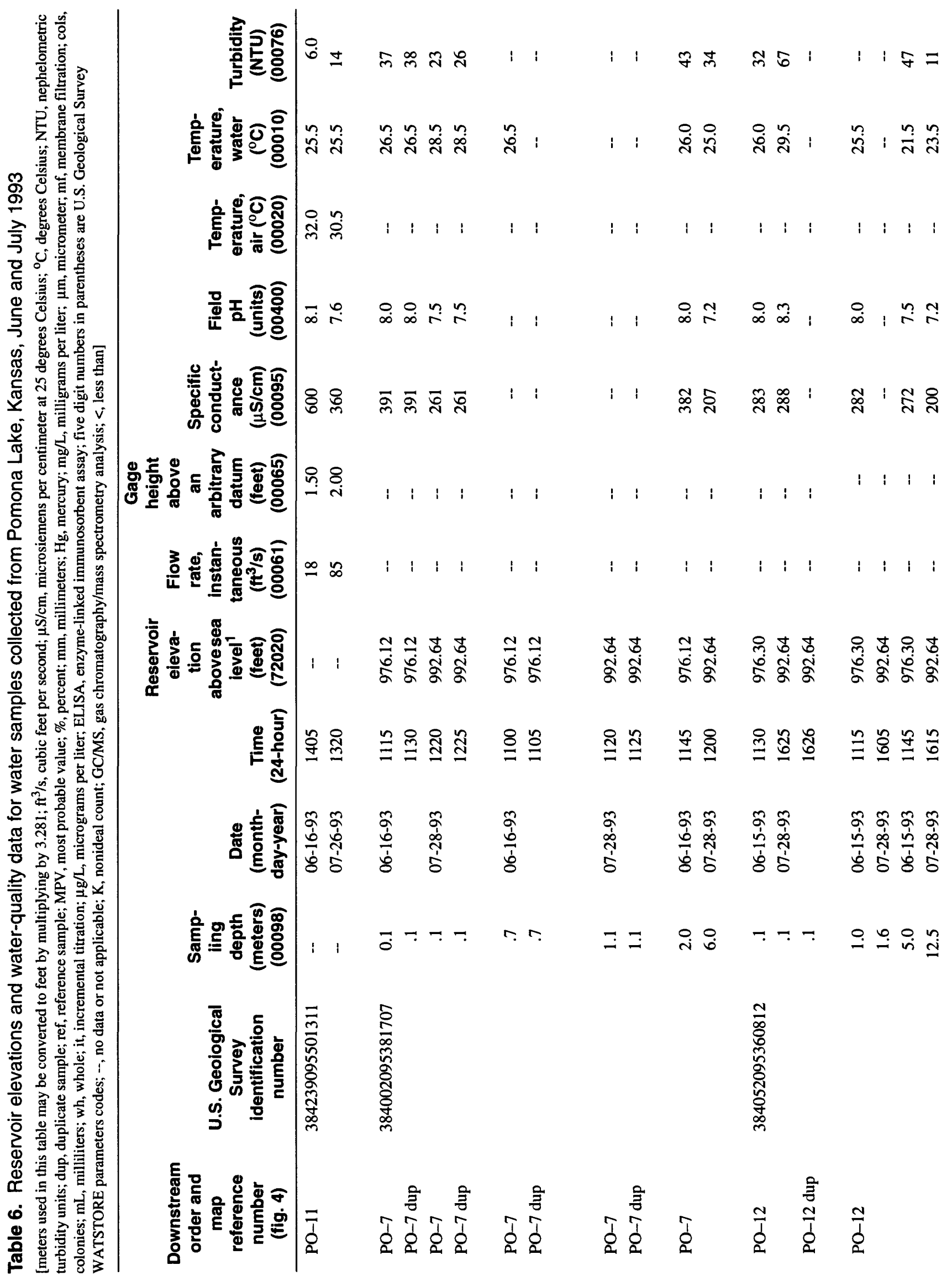

42 Water-Quality Conditions of Inflow, Outflow, and Impounded Water at Rathbun Reservoir, Iowa, Clinton and Pomona Lakes, Kansas, and Harlan County Reservoir, Nebraska, May Through August 1993 


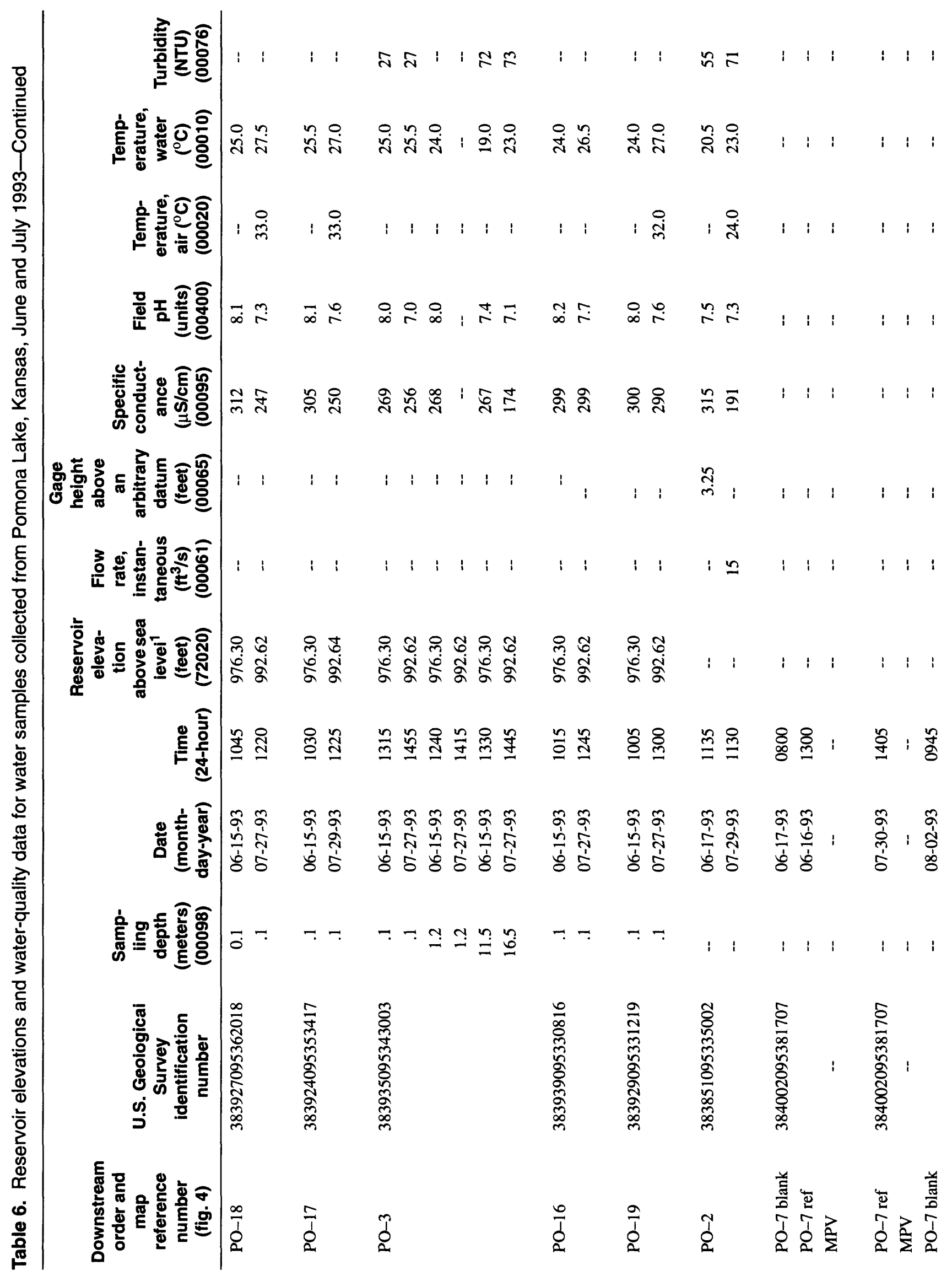




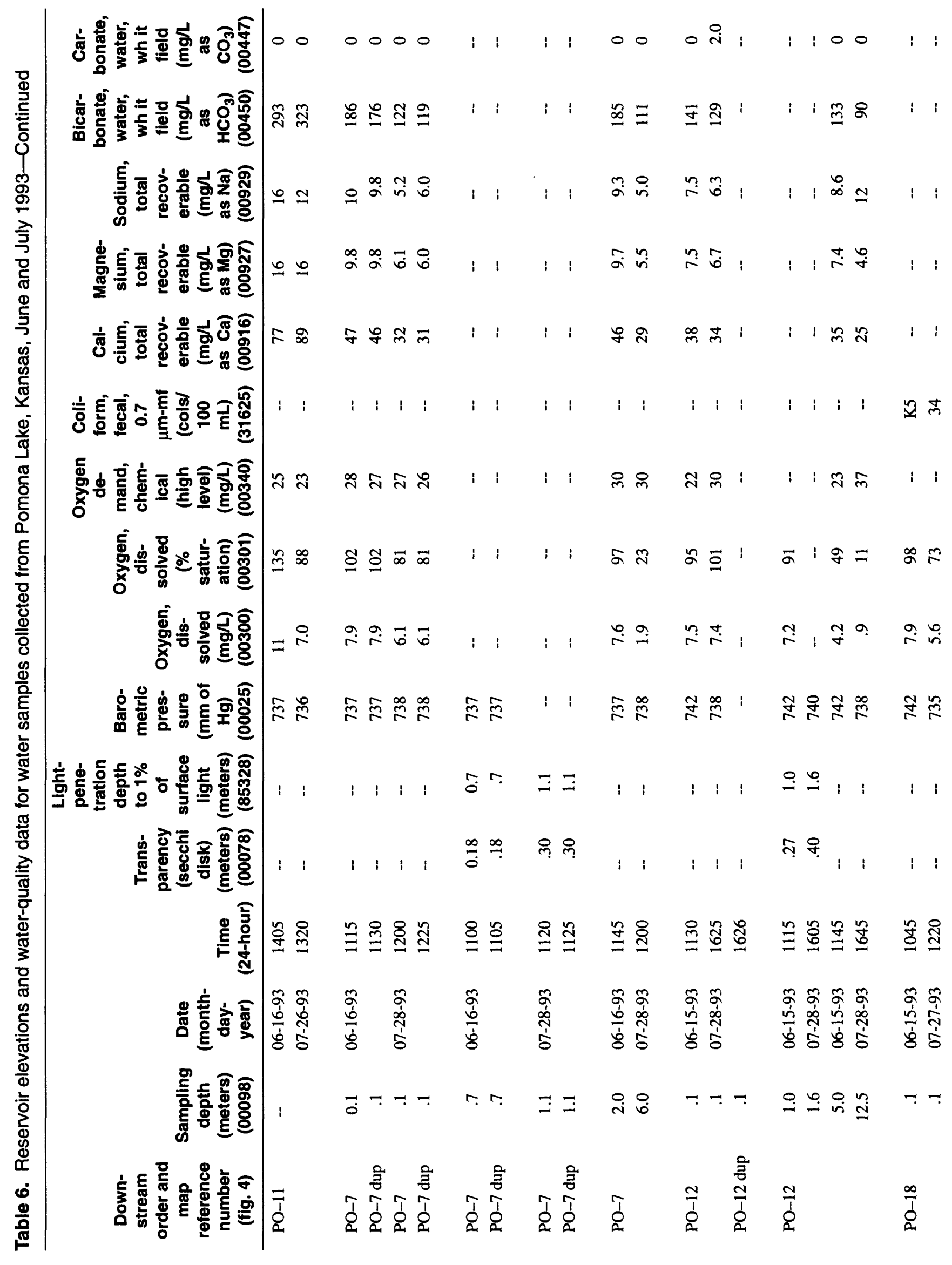

44 Water-Quality Conditions of Inflow, Outflow, and Impounded Water at Rathbun Reservoir, lowa, Clinton and Pomona Lakes, Kansas, and Harlan County Reservoir, Nebraska, May Through August 1993 


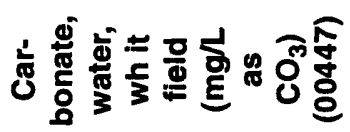

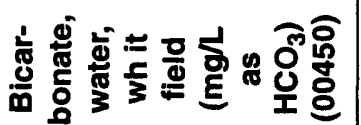

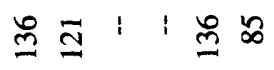
$\stackrel{\infty}{\infty} \infty$

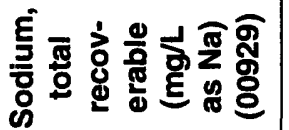

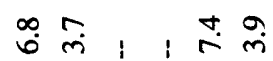

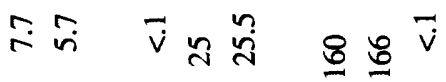

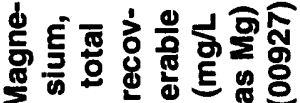

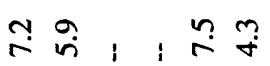
$\dddot{7}$

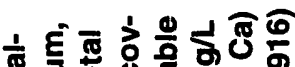

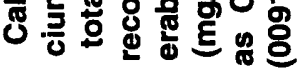

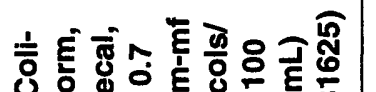

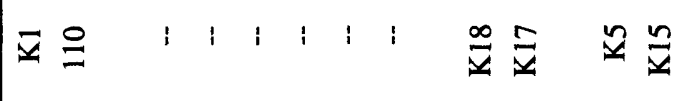

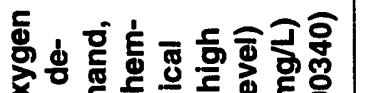

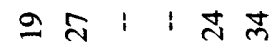
gे $\vec{v}=\stackrel{2}{Q}$ 点 $\vec{v}$

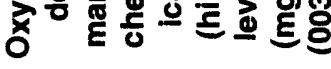

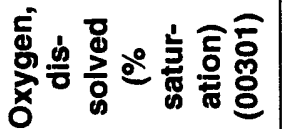

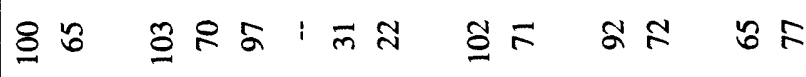

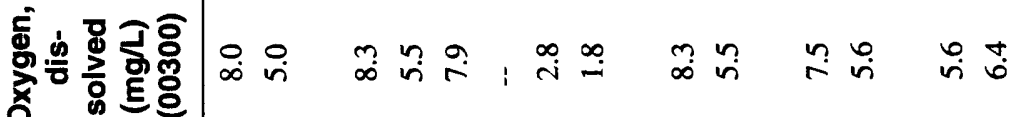

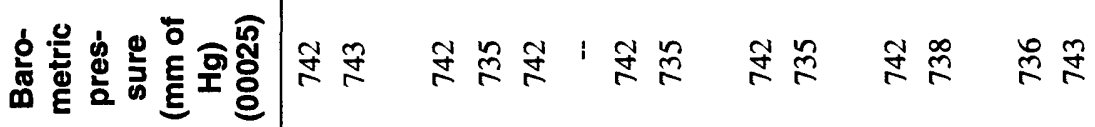
它突

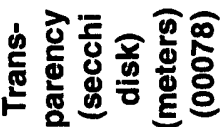

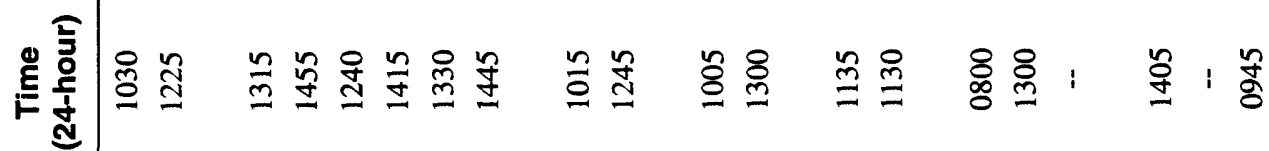

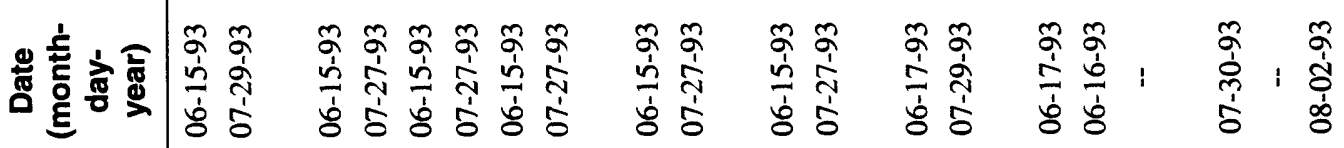

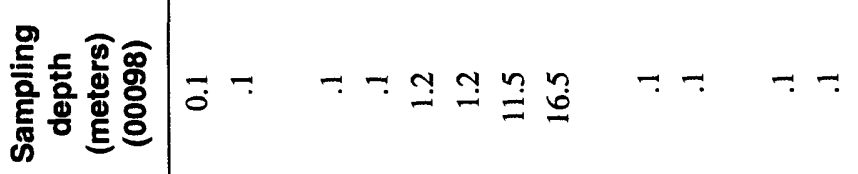




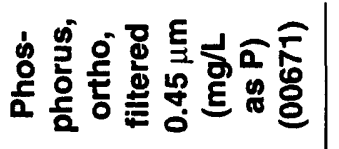

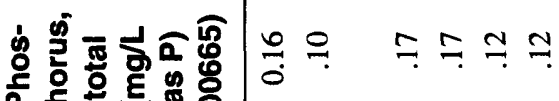

$\overline{0} \%$ ¿

? 8

此

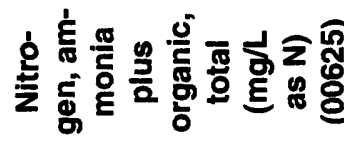

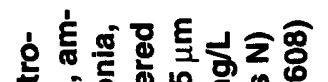

之 ฐँ

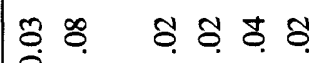

$\because \div \quad \div \%$

$=$ ㅇํ

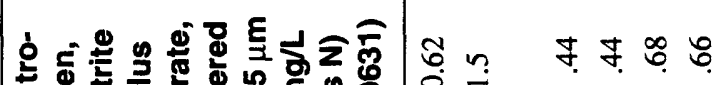

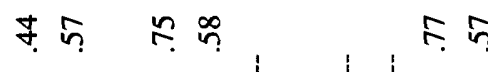

tin $\Re \stackrel{\infty}{n}, \quad$,

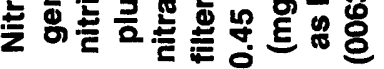

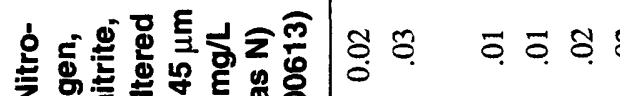

कำ

$\ddot{v} \dot{v}$

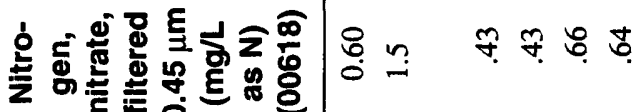

भ.

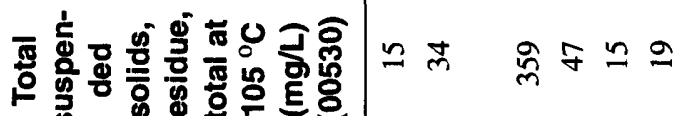

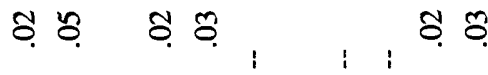

之or

훙 톨

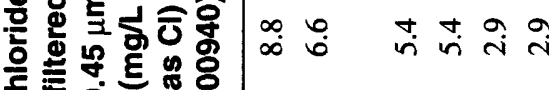

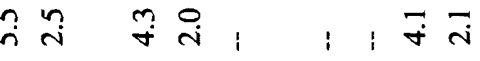

施

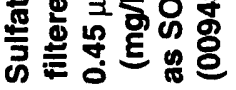

ㅇำ 유ำ 유 유

$1+1$

$\bar{n}$

$\simeq$ \& $1:$ :

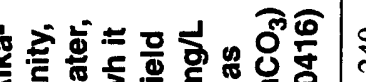

ㅇํำ

$\stackrel{\sim}{\sim}$

$\stackrel{2}{0}$

1 용

䓛亭

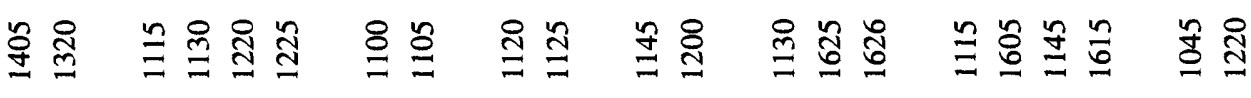

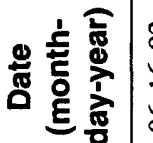

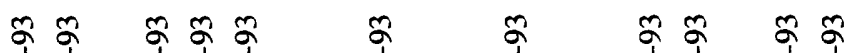

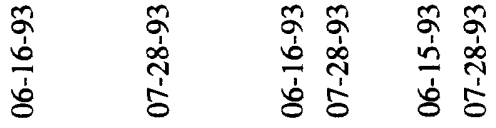

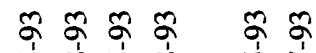

인

\&े

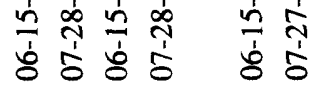

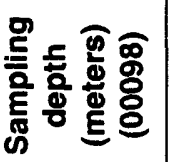

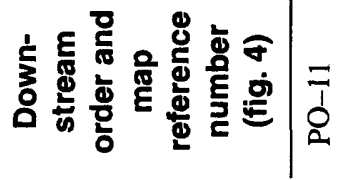

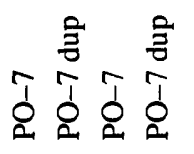

iิ

ำ

우요.

$\neg-$

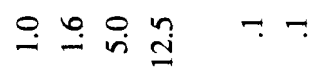




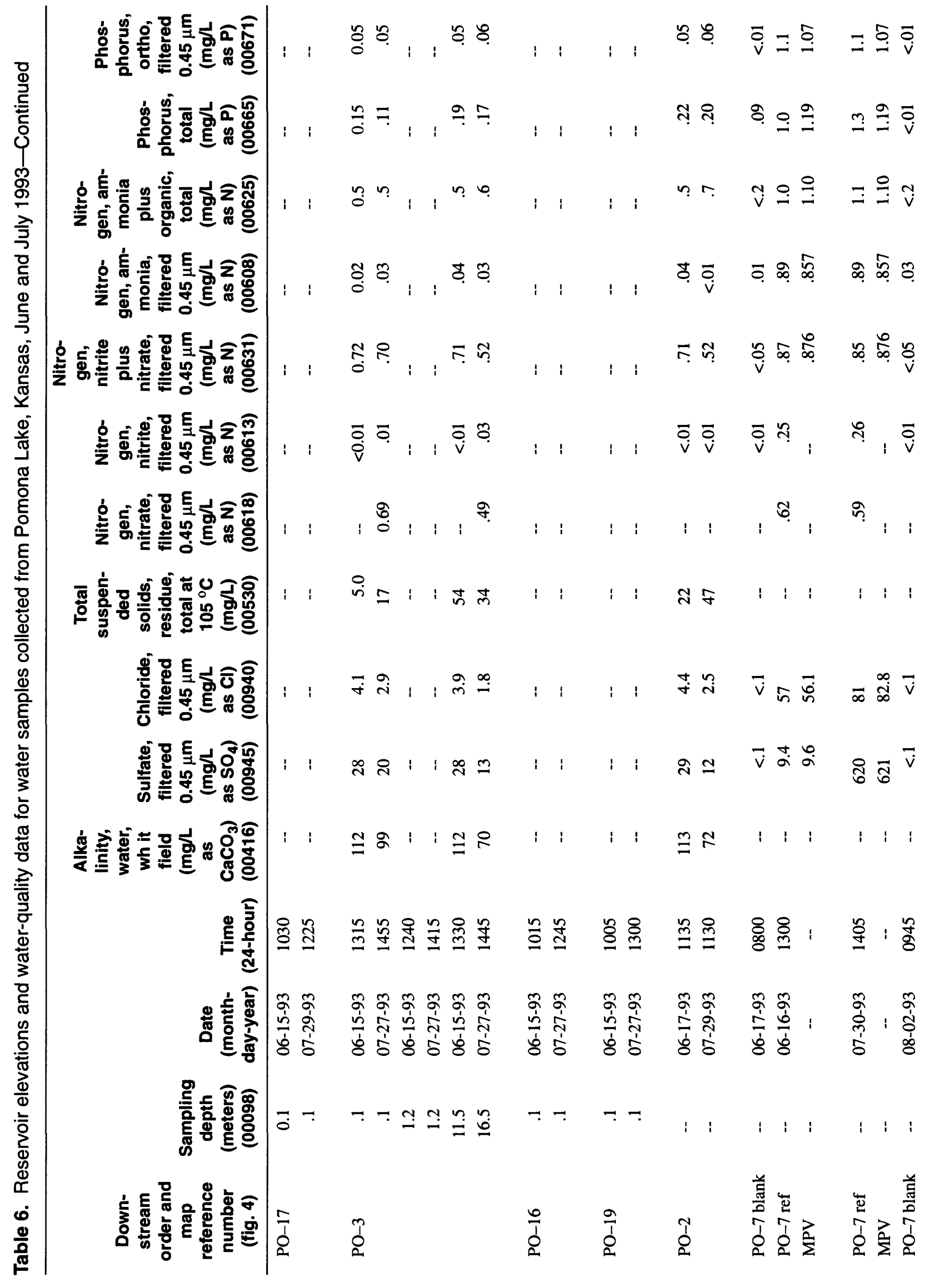




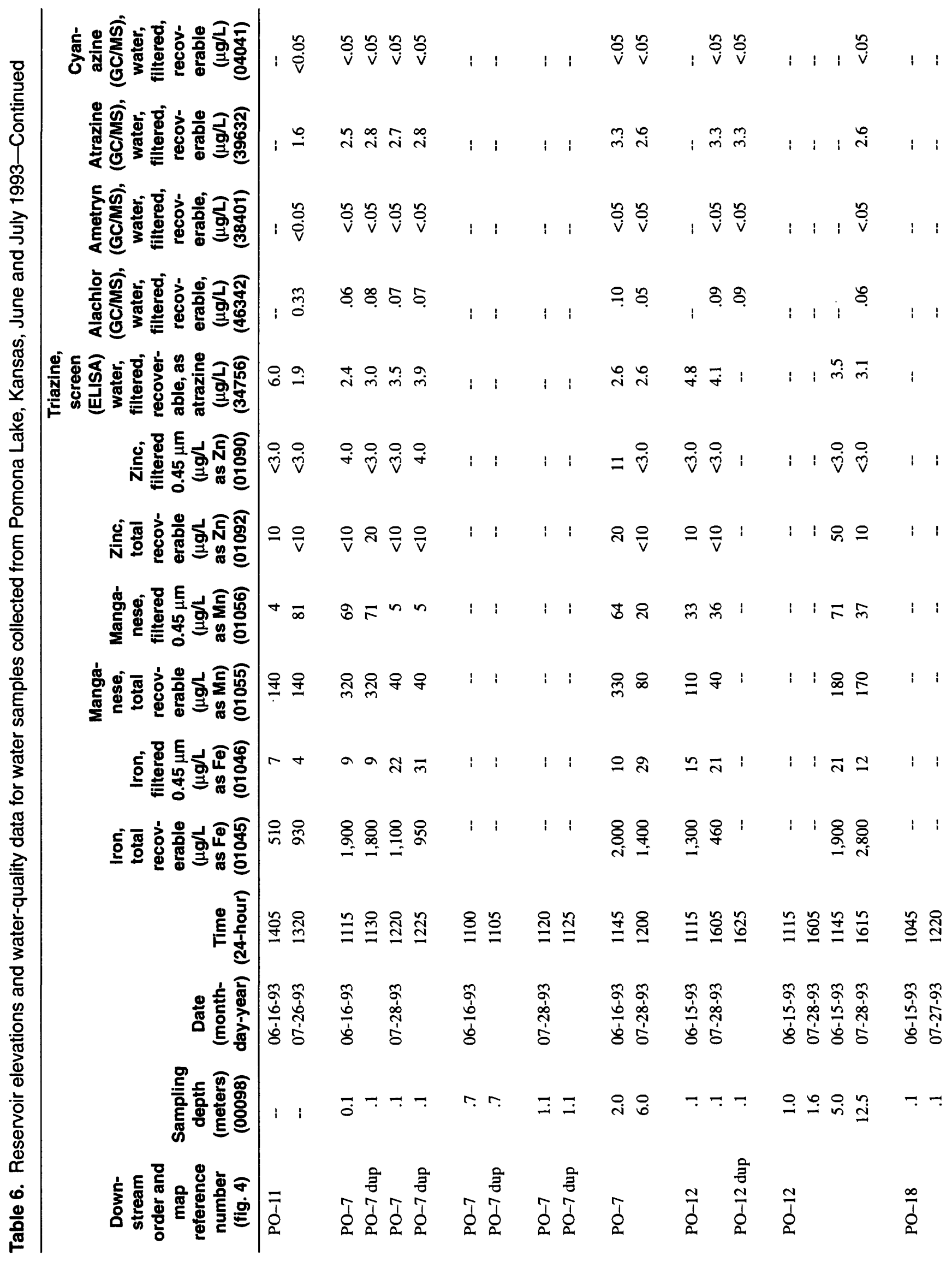




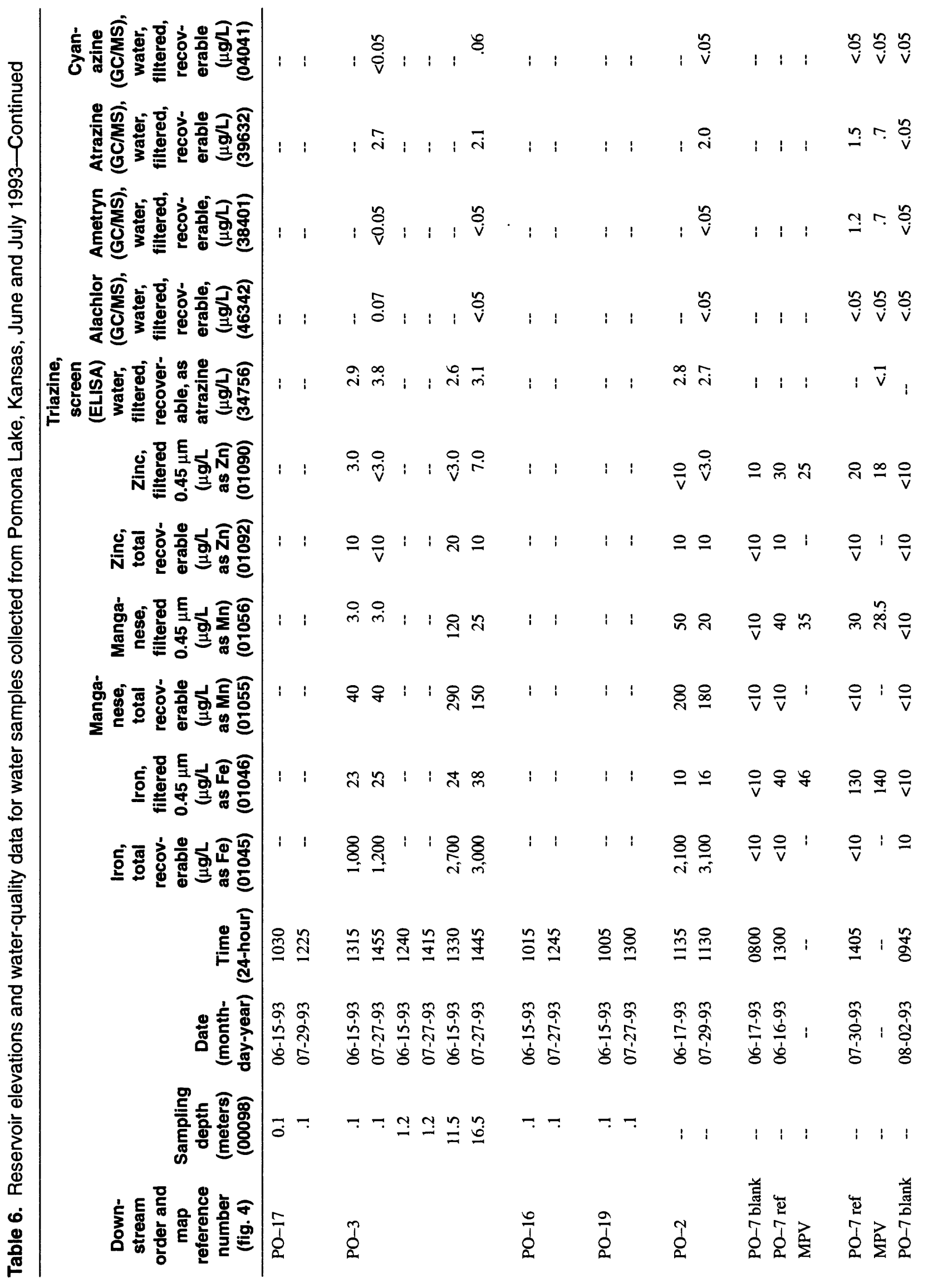




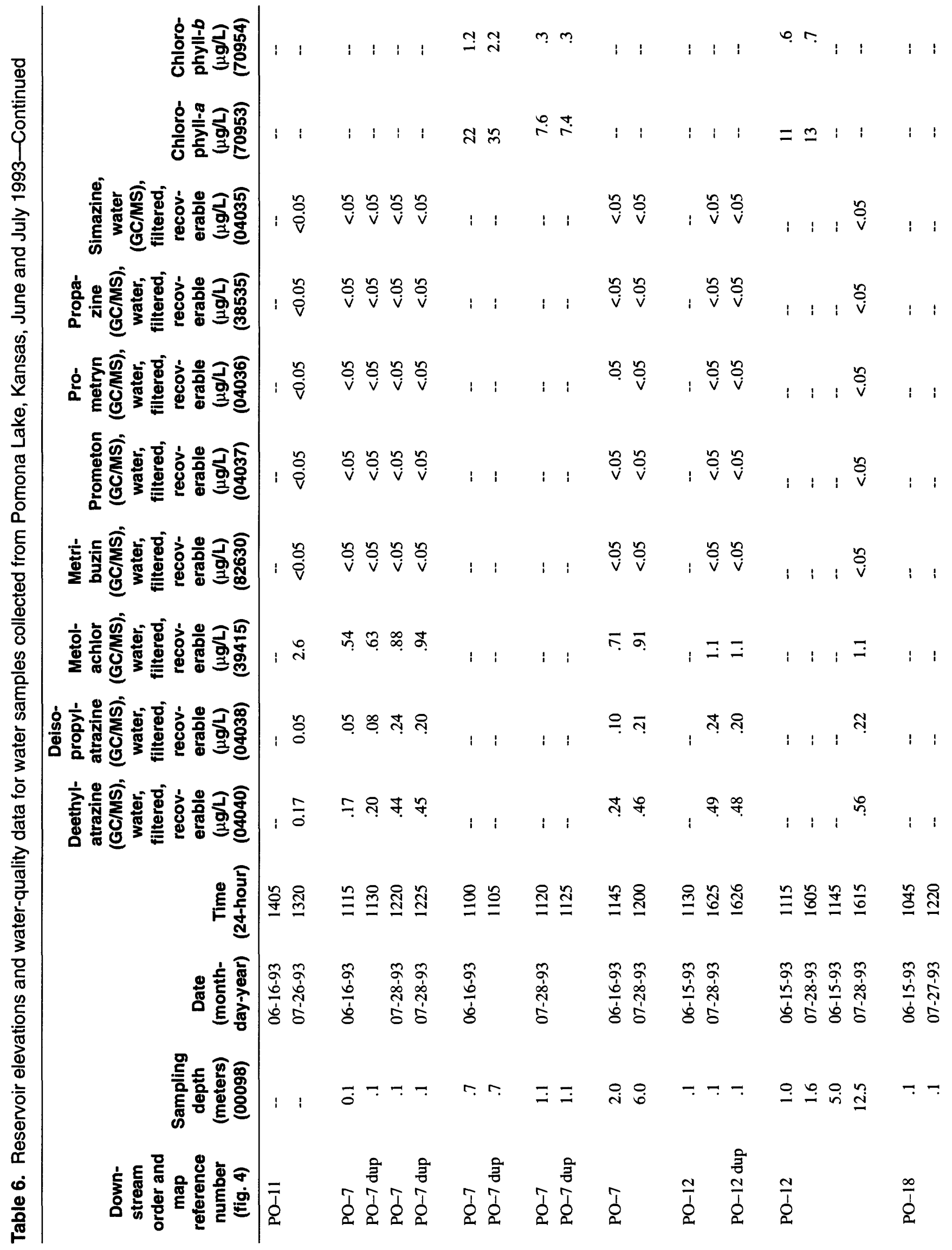




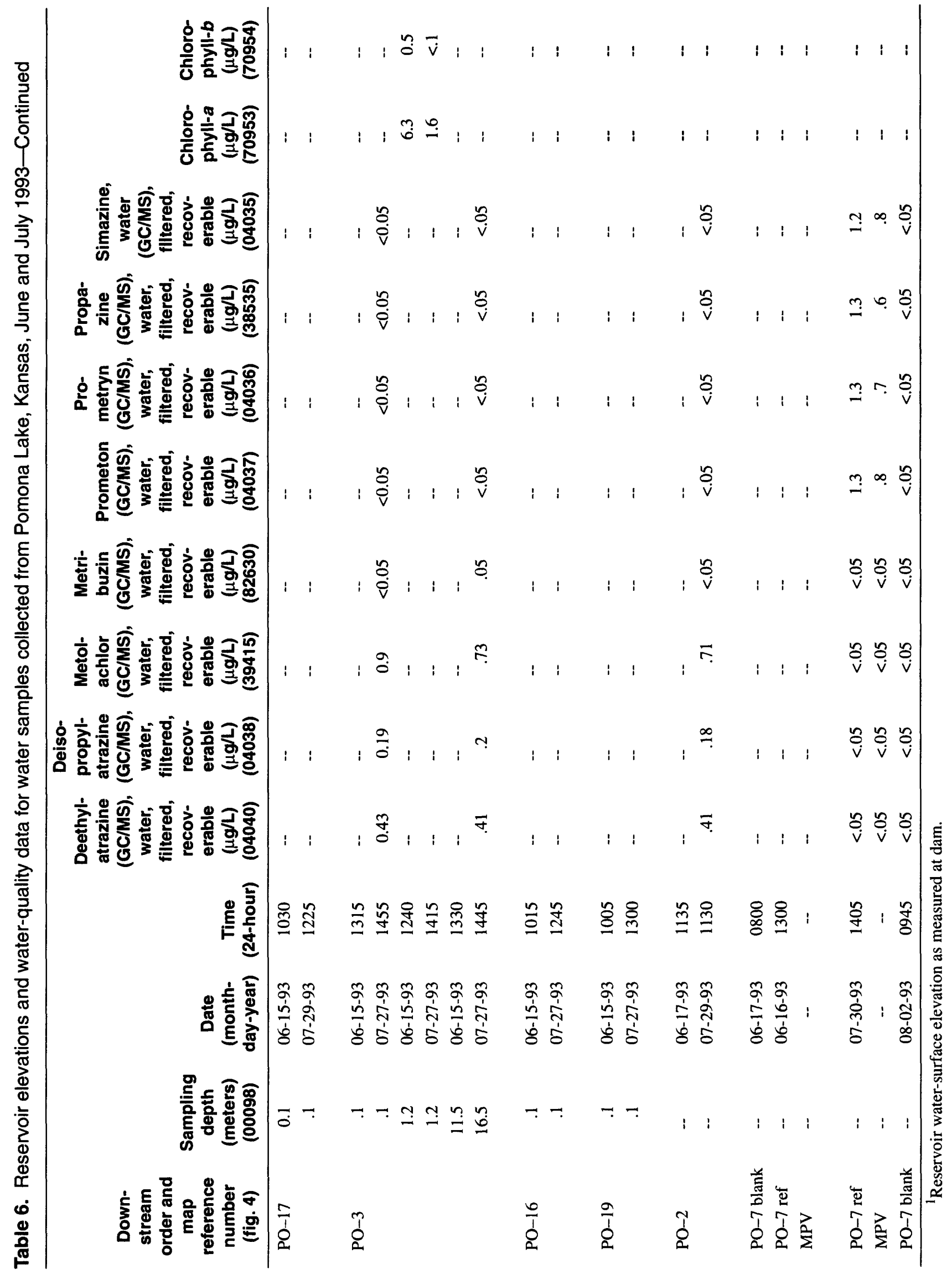




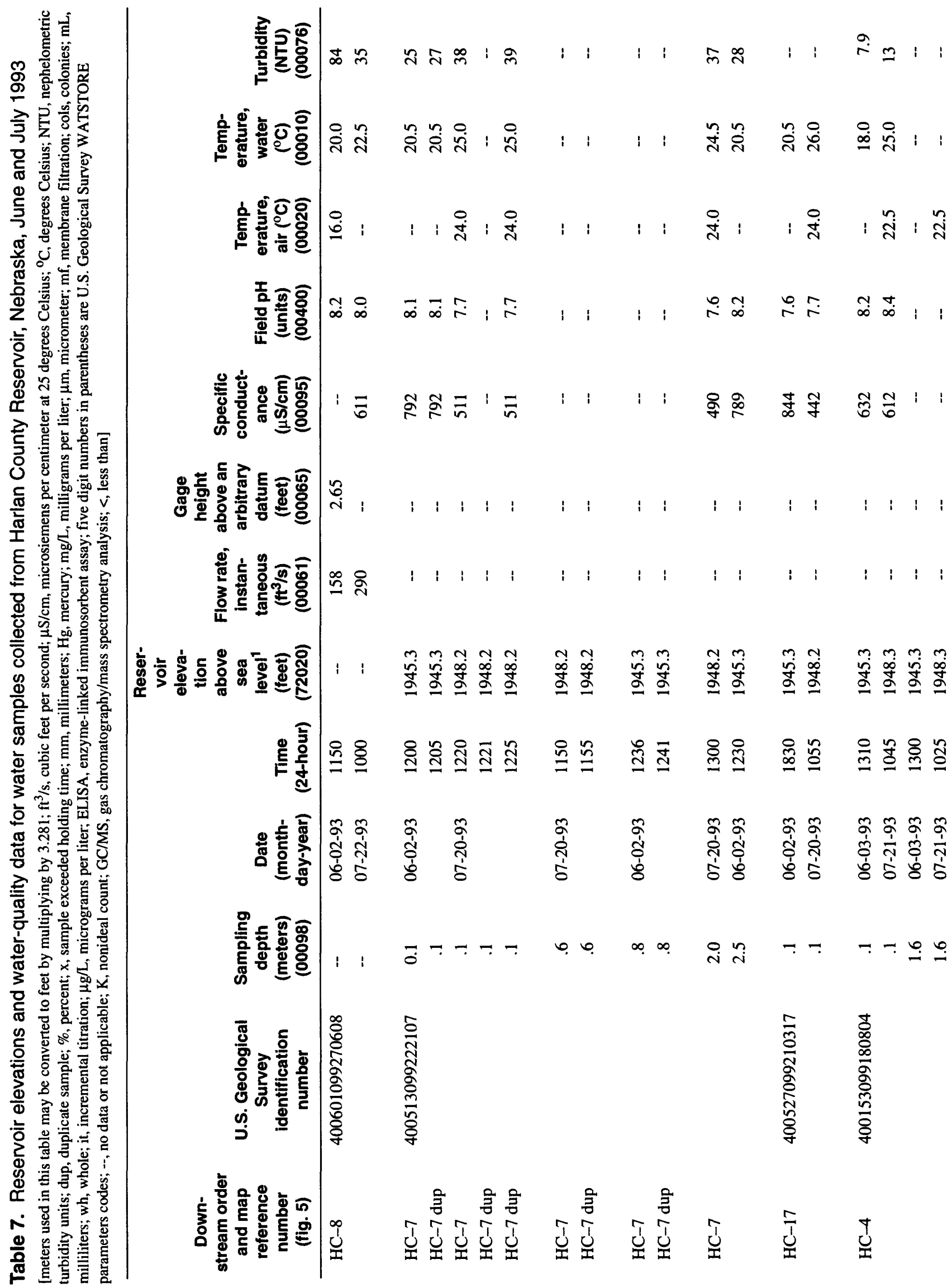

52 Water-Quality Conditions of Inflow, Outflow, and Impounded Water at Rathbun Reservoir, lowa, Clinton and Pomona Lakes, Kansas, and Harlan County Reservoir, Nebraska, May Through August 1993 


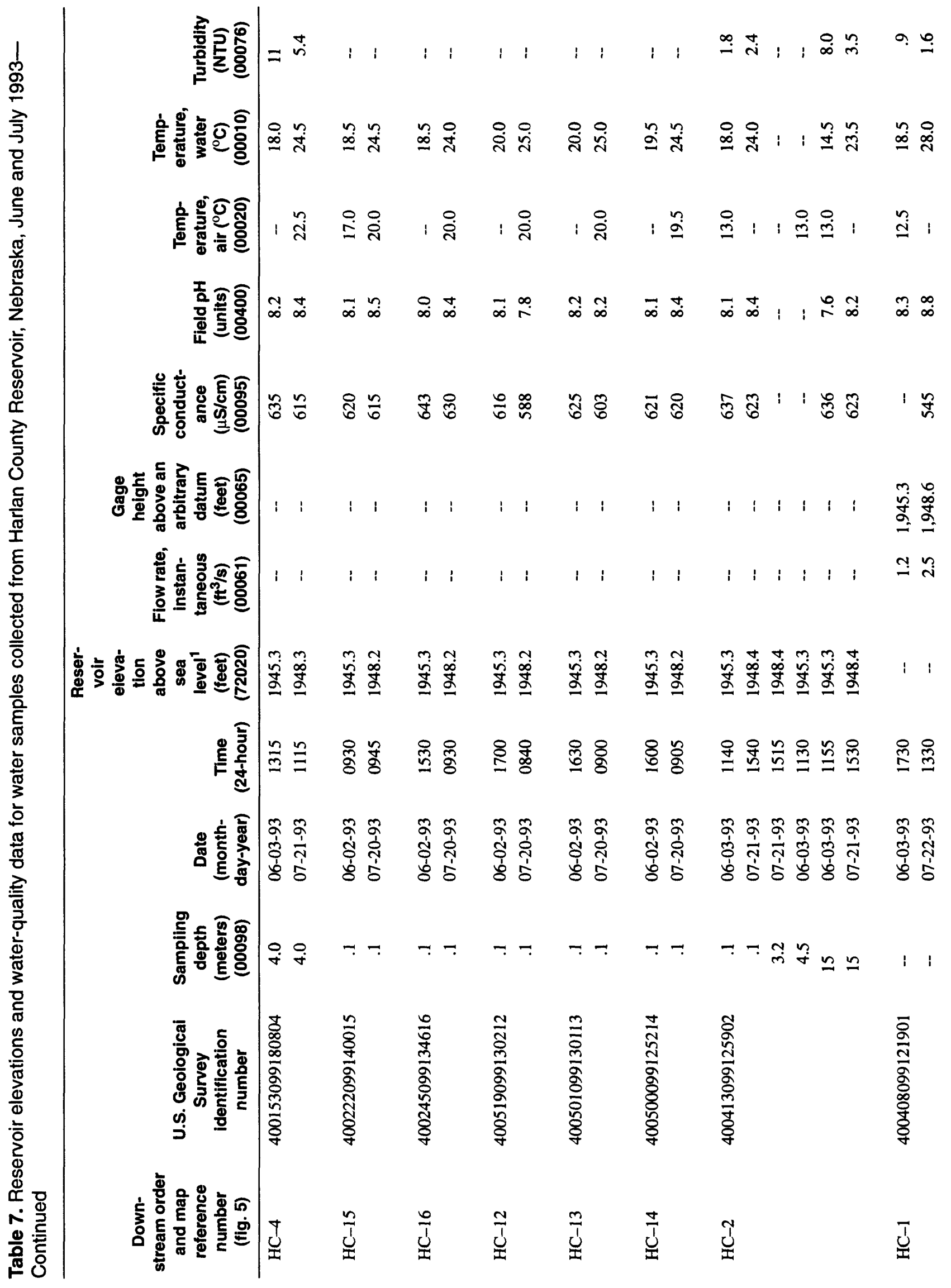




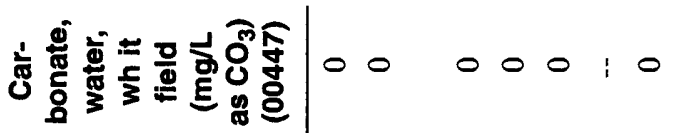

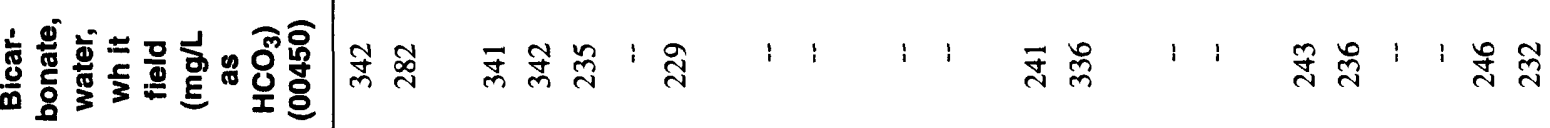

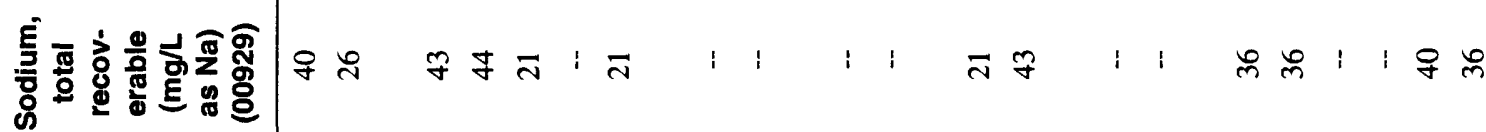

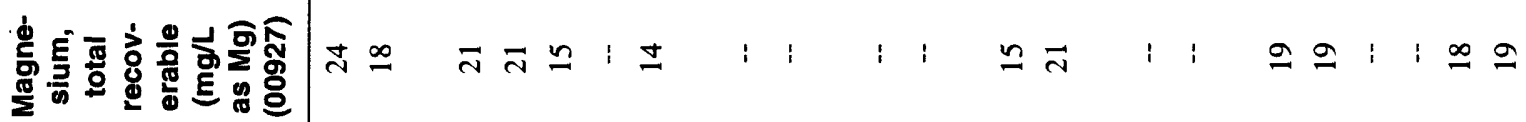

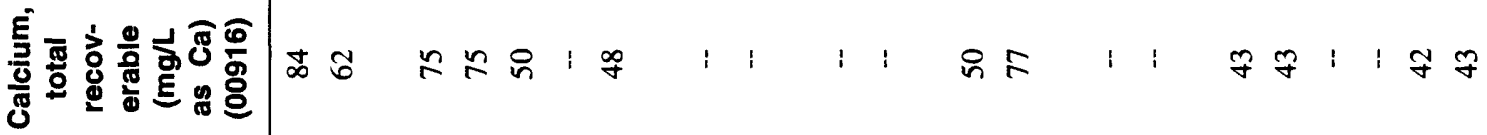

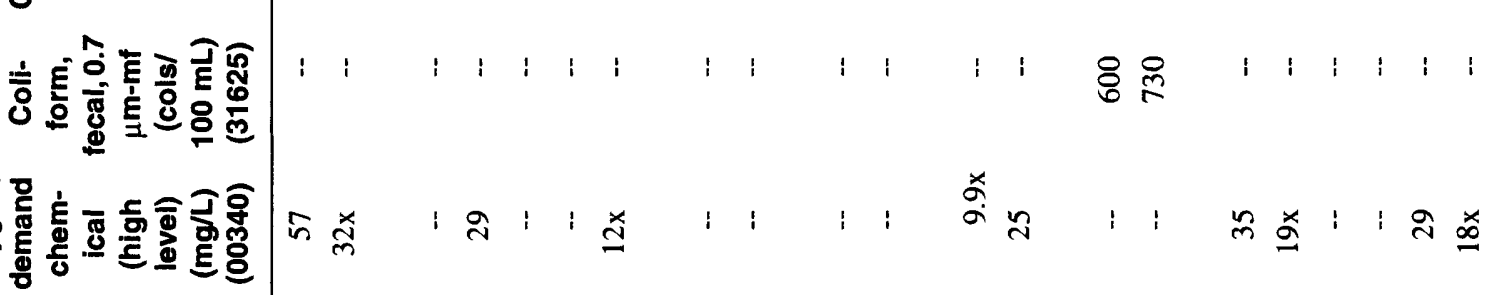

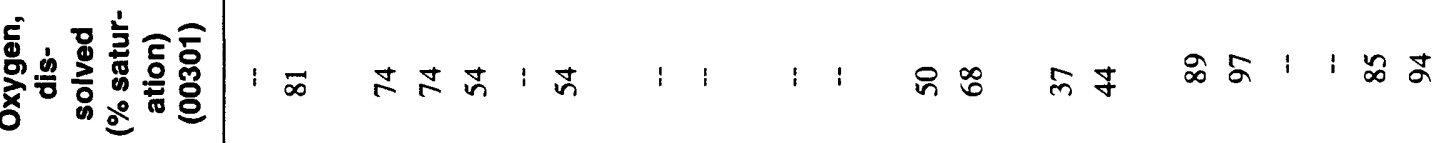

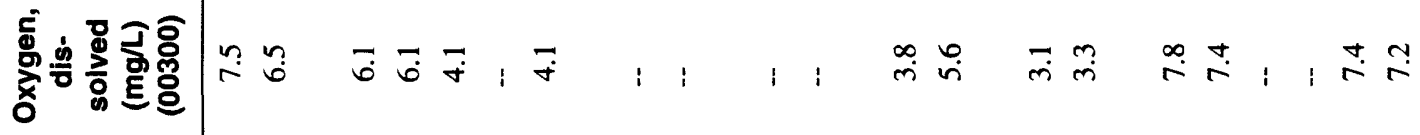

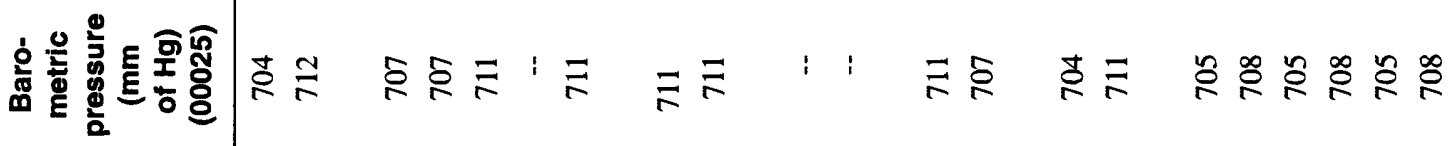

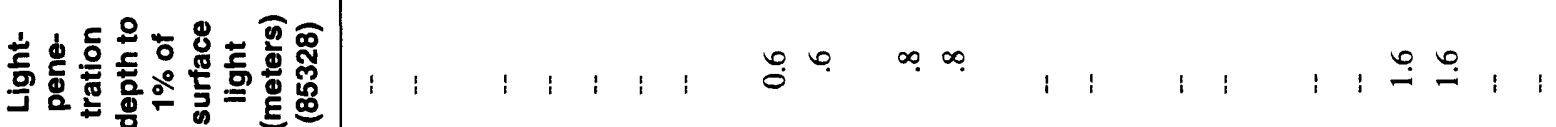

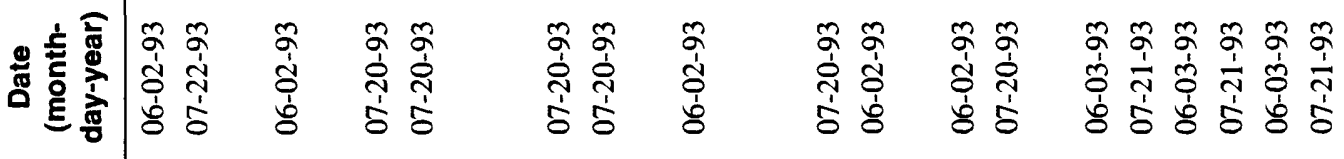

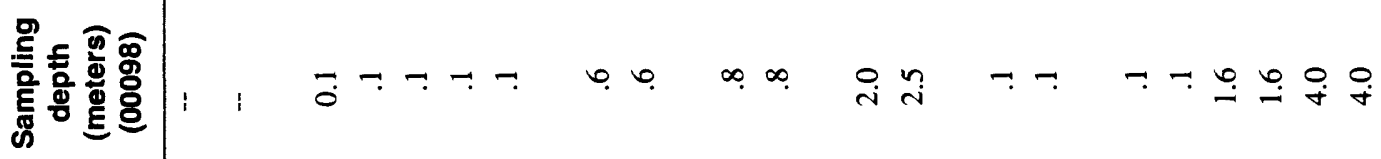




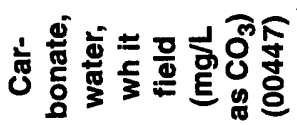

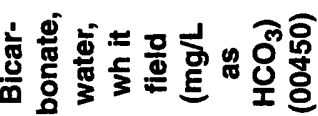

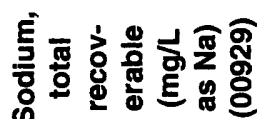

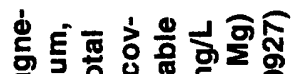

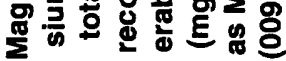

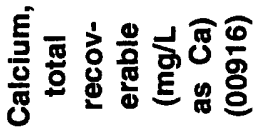

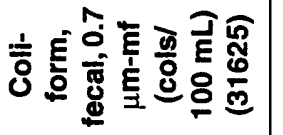

ก

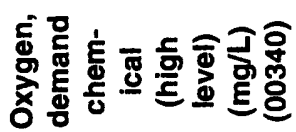

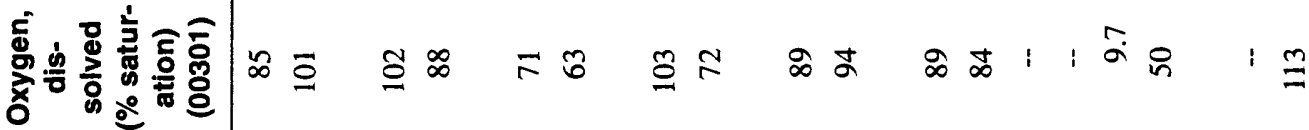

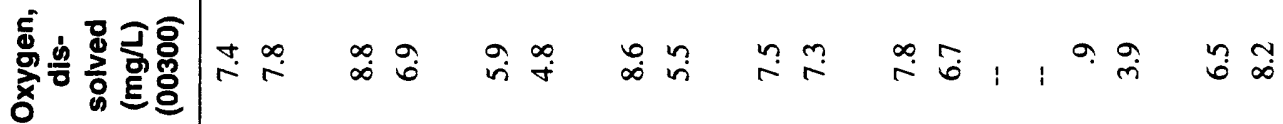

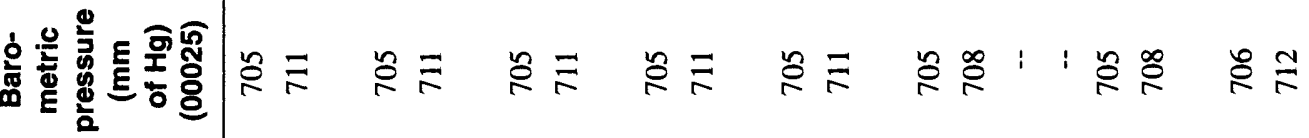

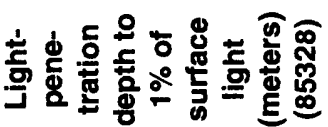
总焉

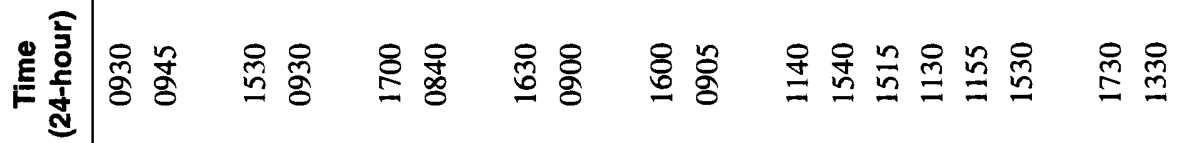

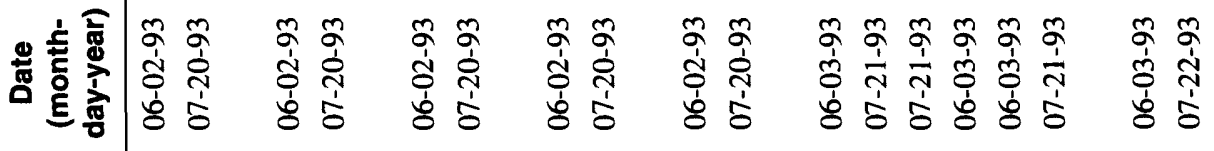

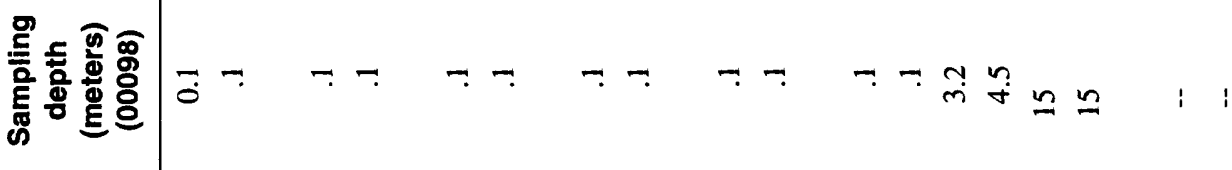

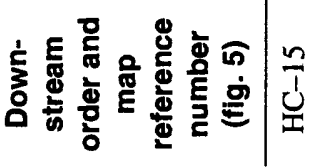

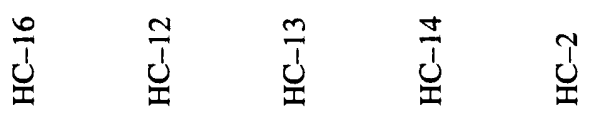
¿̇ं 


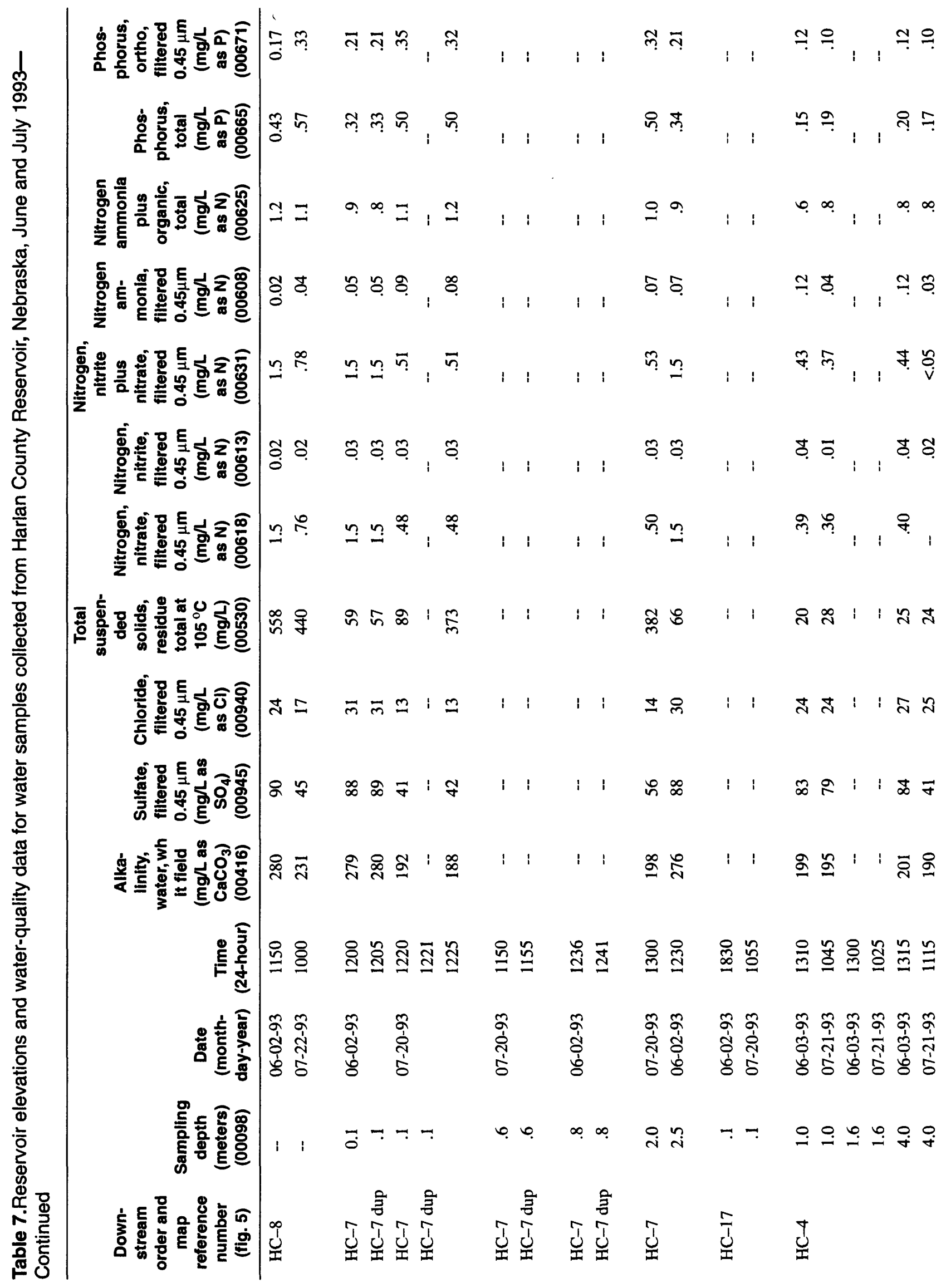

56 Water-Quality Conditions of Inflow, Outflow, and Impounded Water at Rathbun Reservoir, lowa, Clinton and Pomona Lakes, Kansas, and Harlan County Reservoir, Nebraska, May Through August 1993 


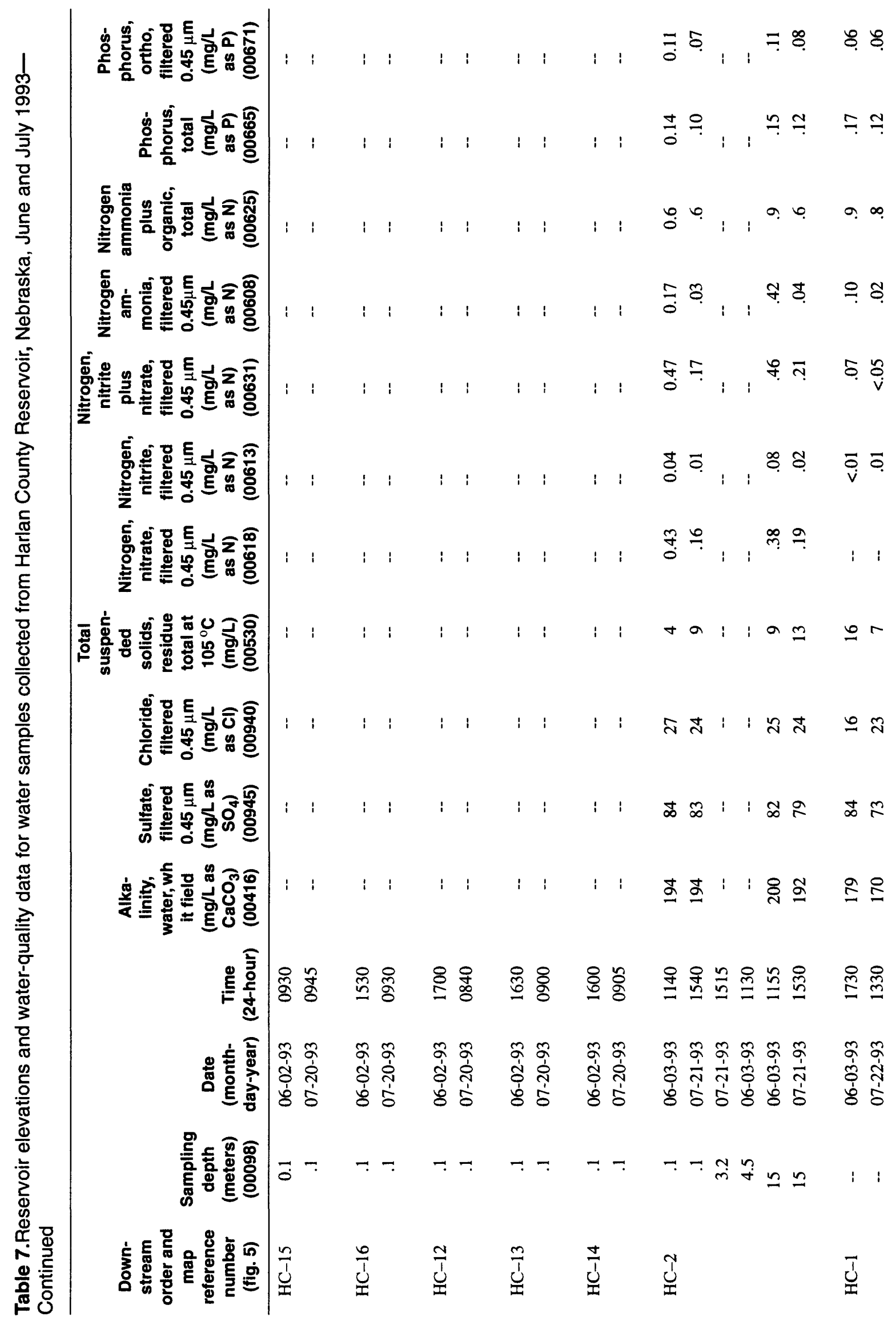




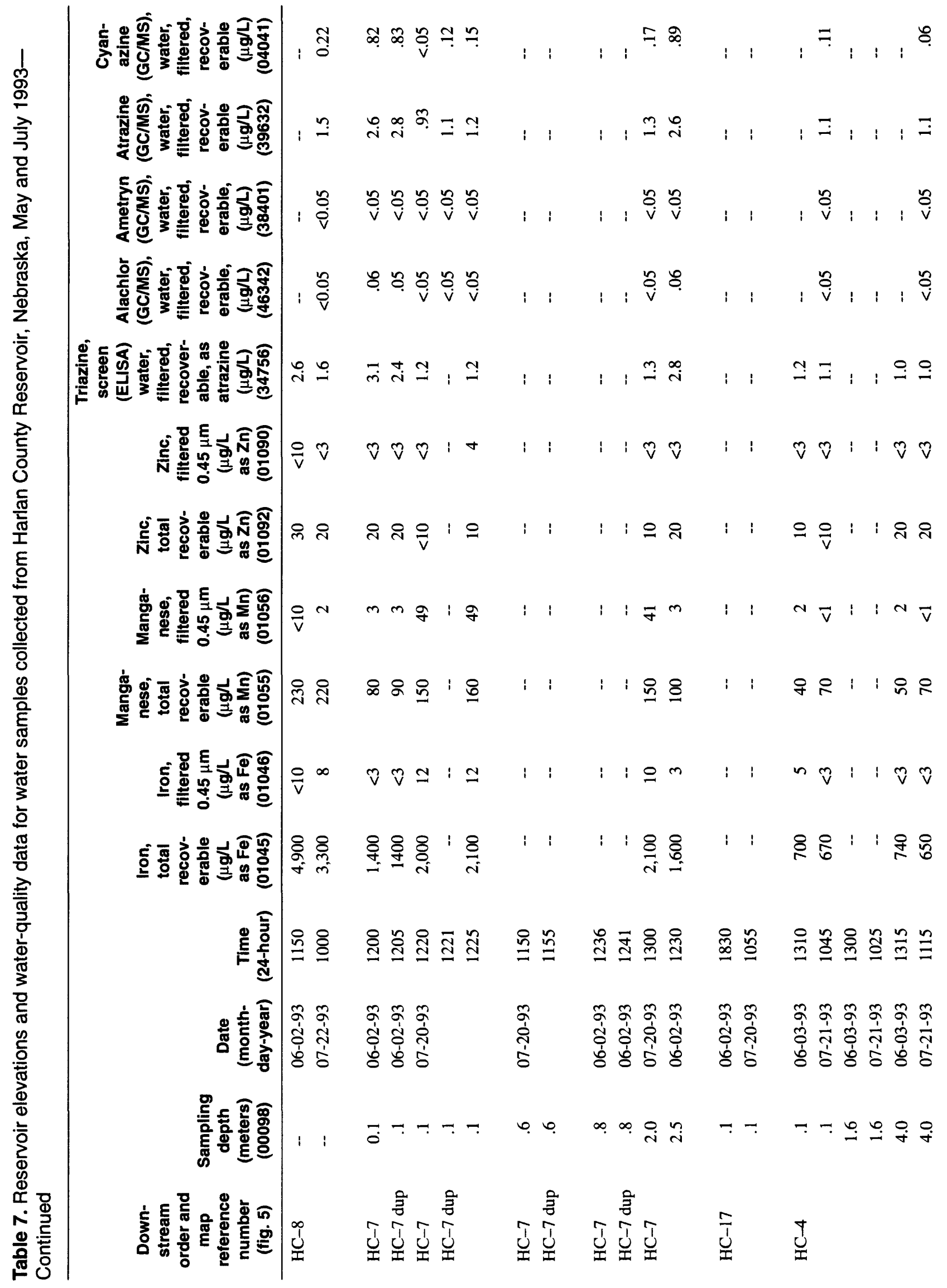




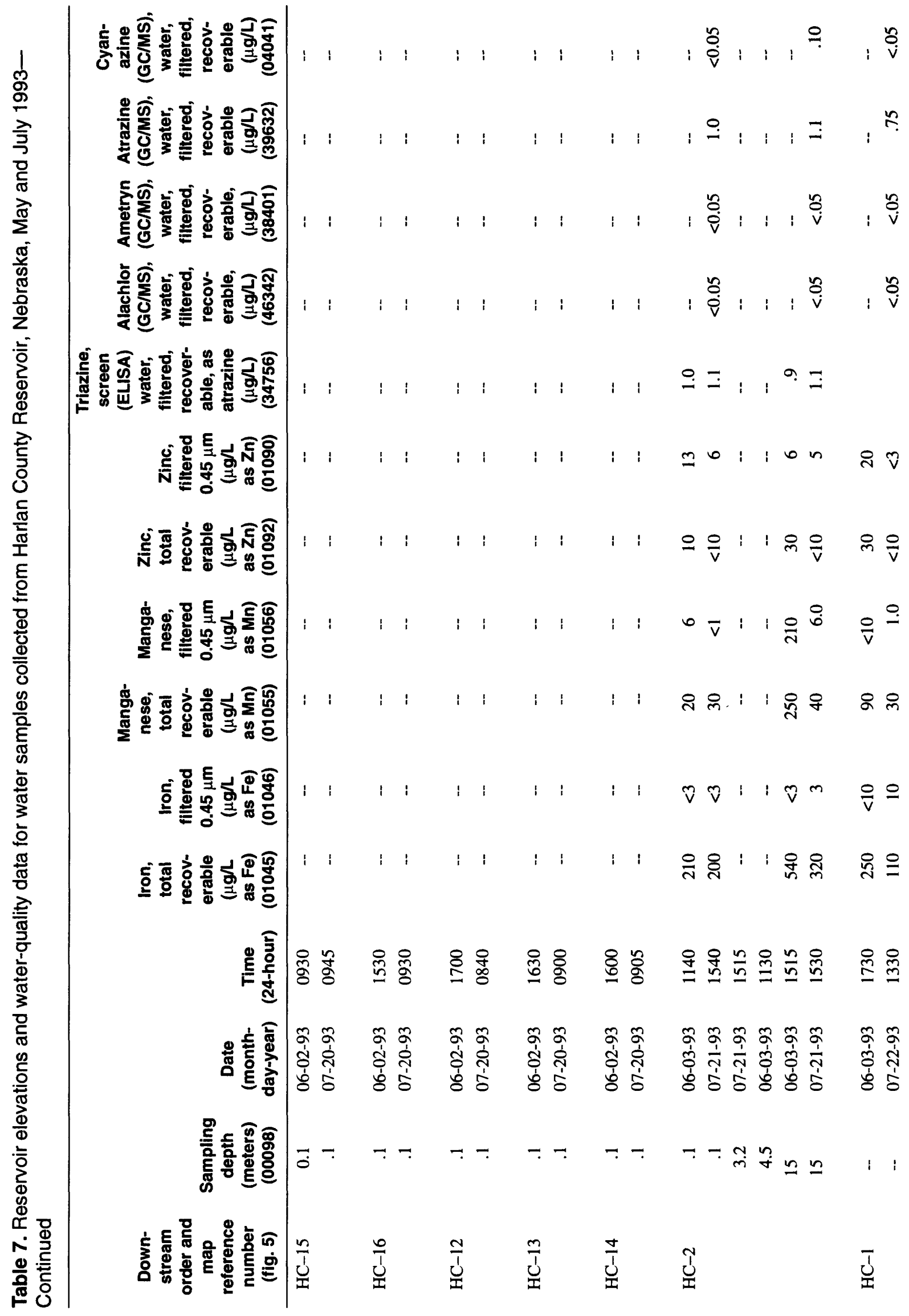




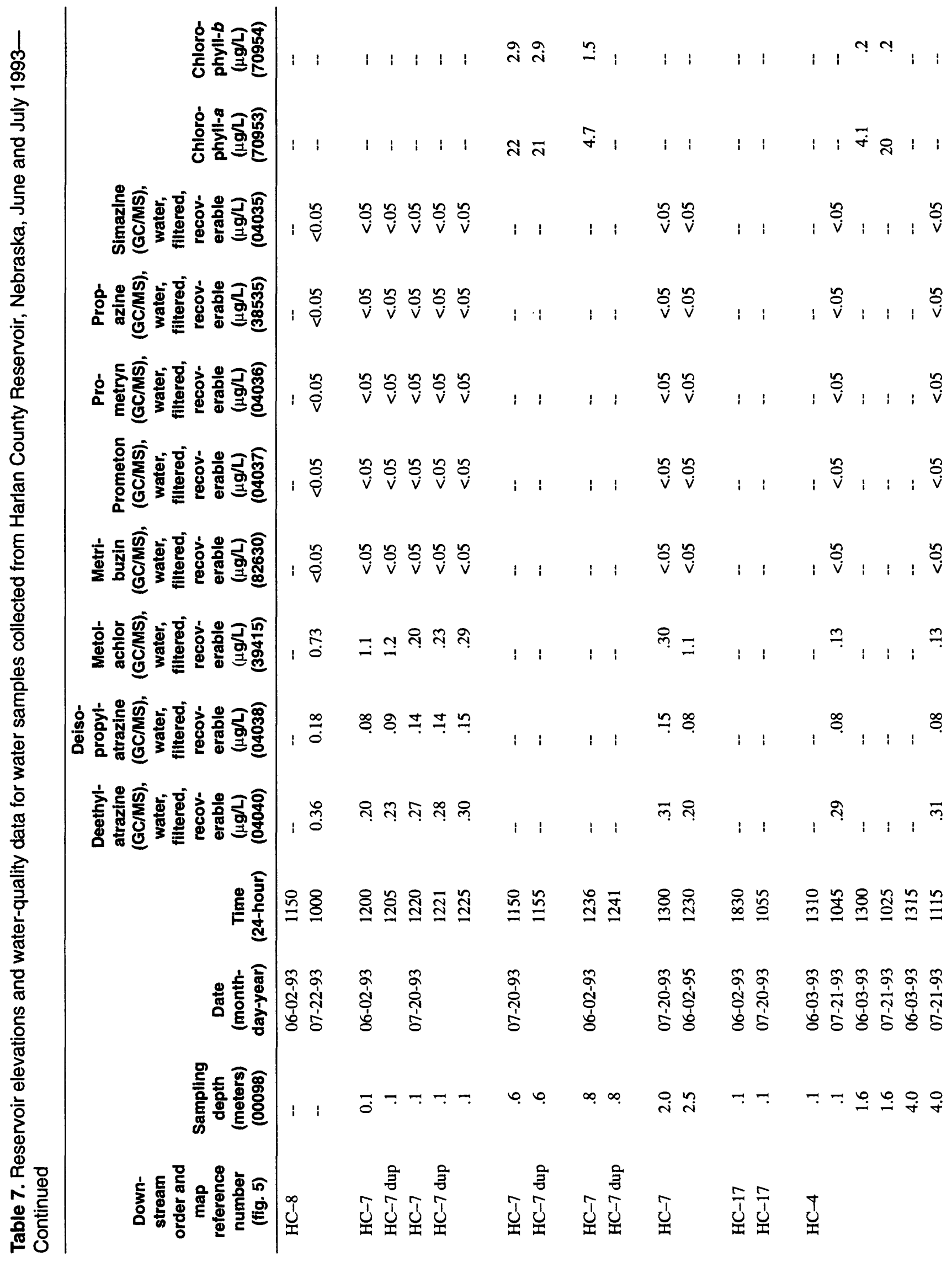

60 Water-Quality Conditions of Inflow, Outflow, and impounded Water at Rathbun Reservoir, lowa, Clinton and Pomona Lakes, Kansas, and Harian County Reservoir, Nebraska, May Through August 1993 


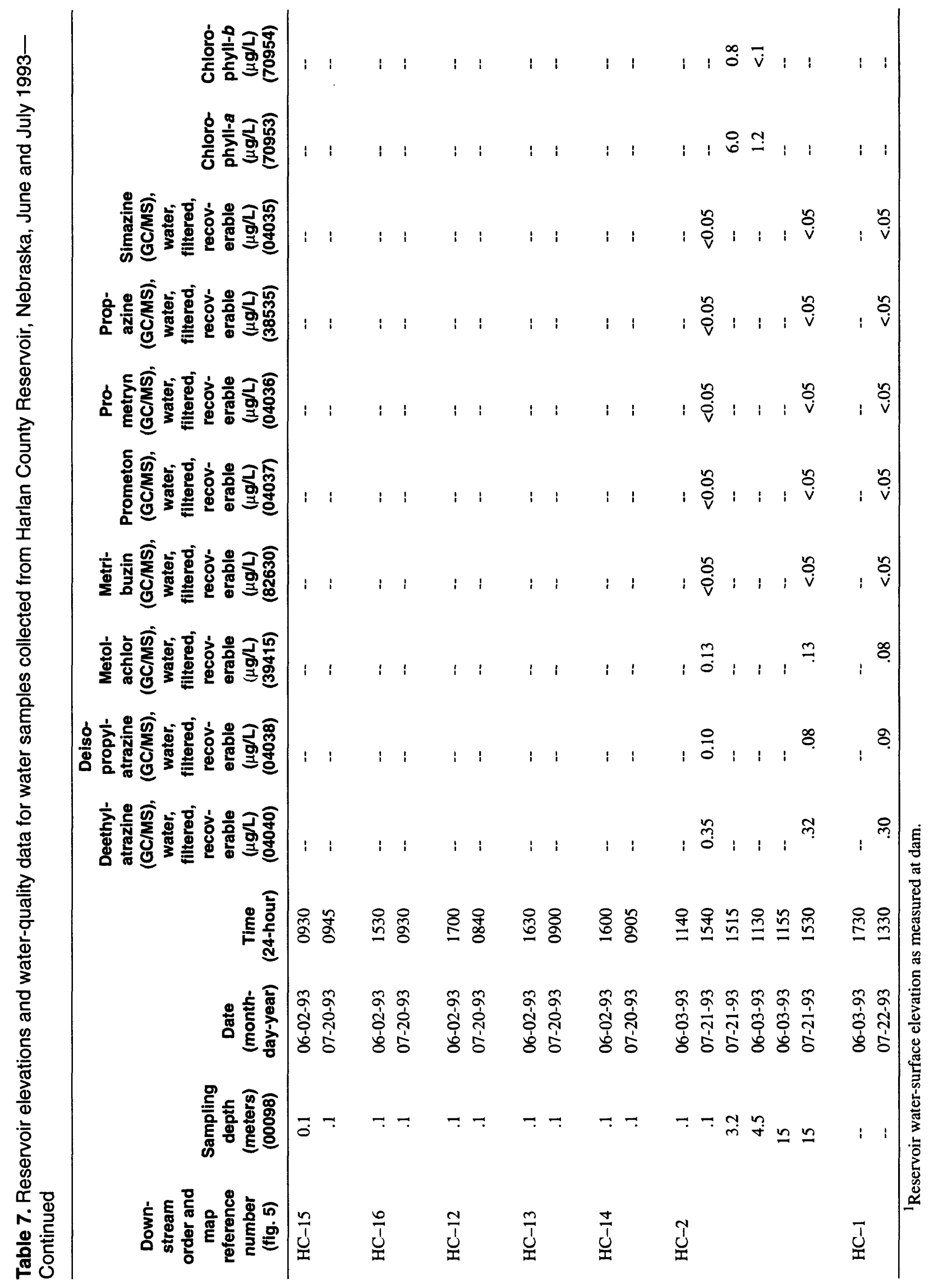




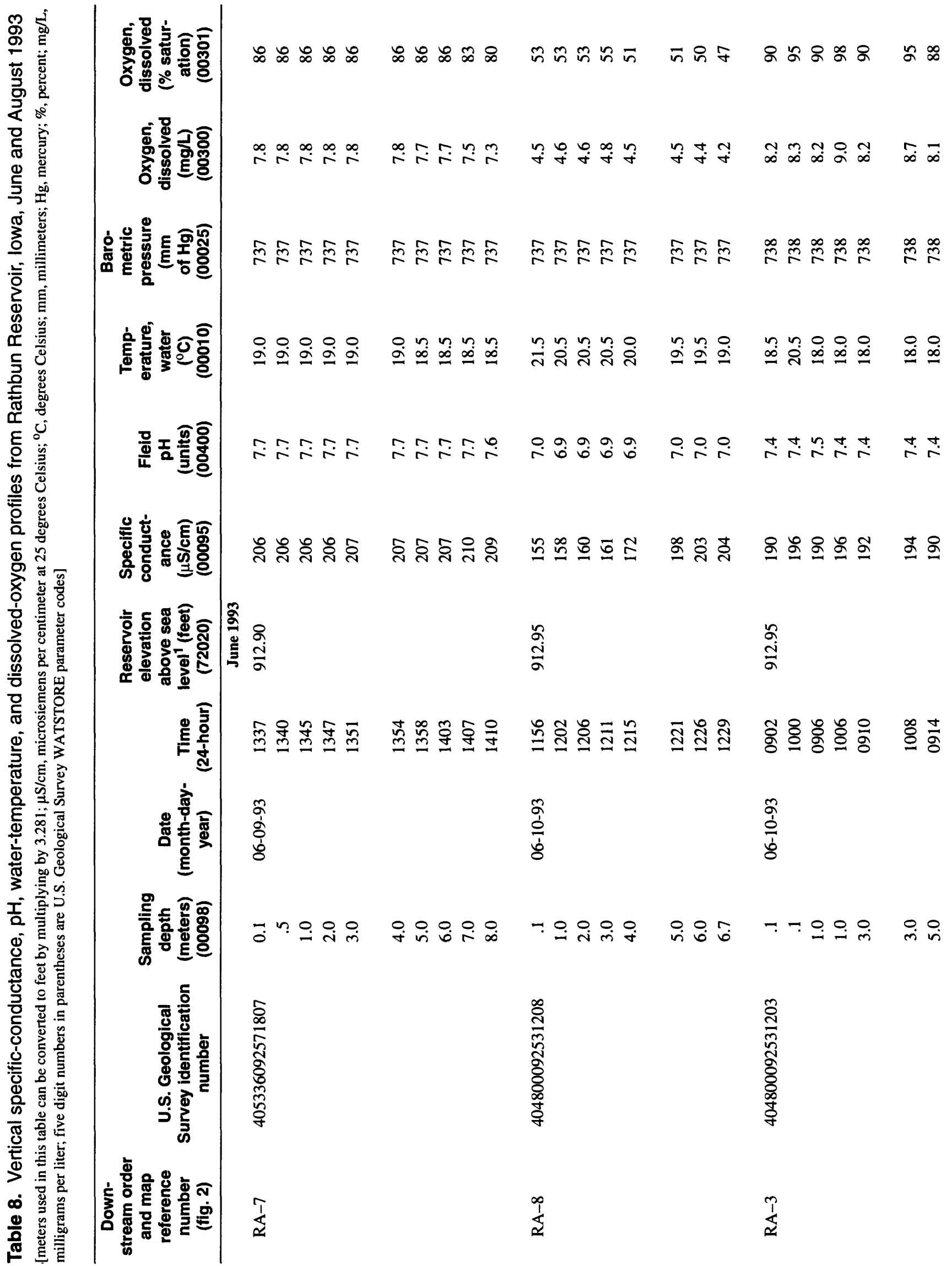

62 Water-Quality Conditions of Inflow, Outflow, and Impounded Water at Rathbun Reservoir, lowa, Clinton and Pomona Lakes, Kansas, and Harlan County Reservoir, Nebraska, May Through August 1993 


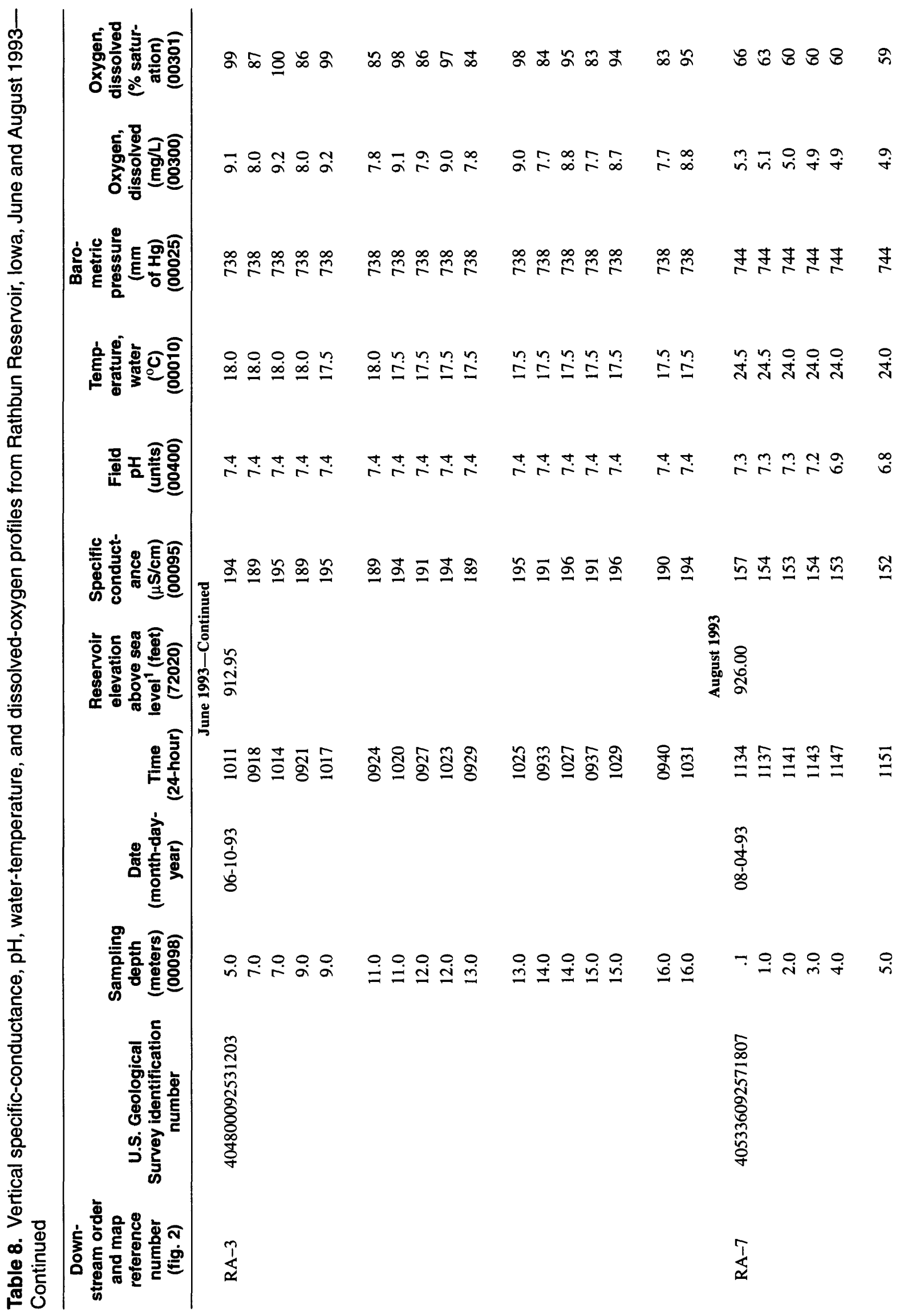




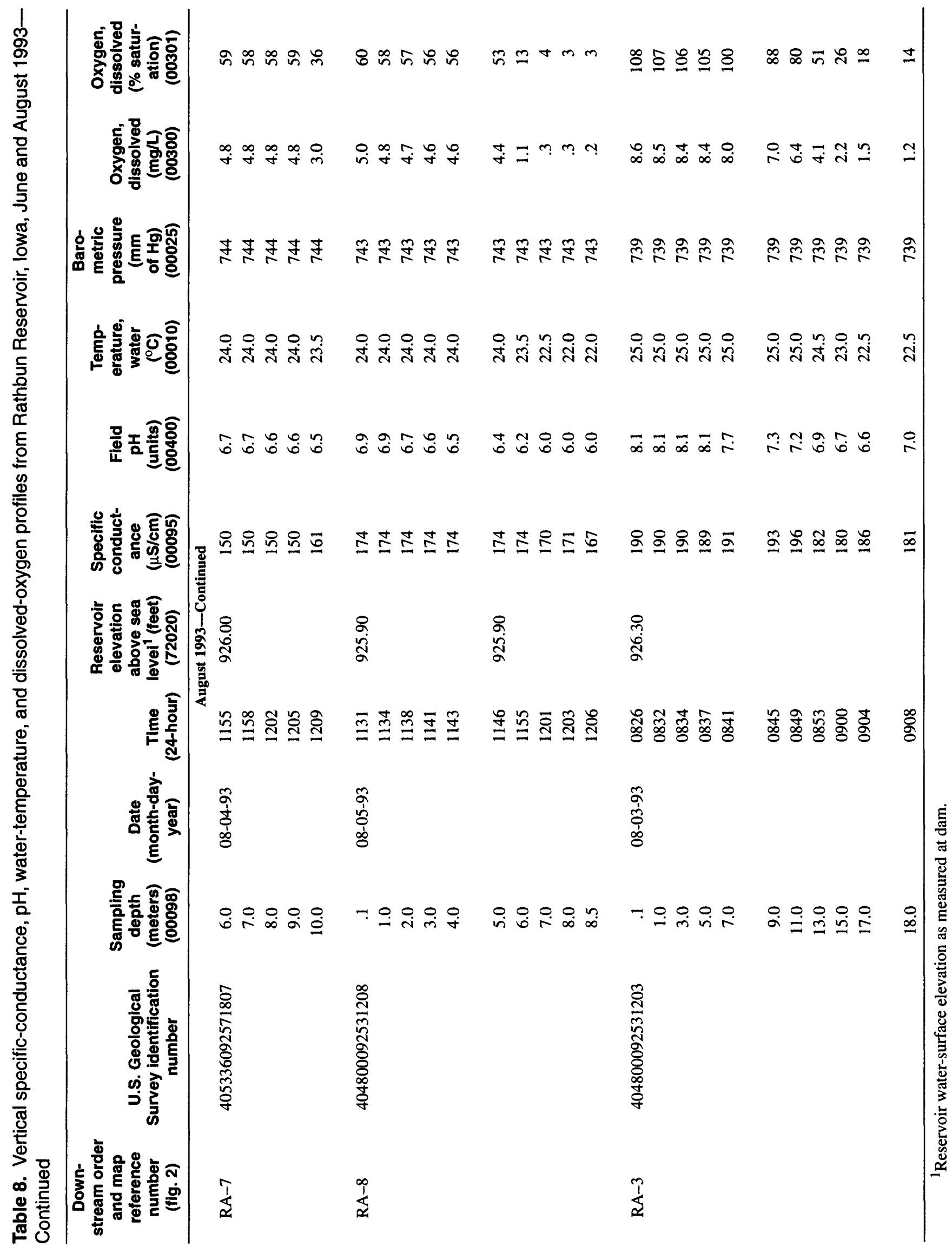

64 Water-Quality Conditions of Inflow, Outflow, and Impounded Water at Rathbun Reservoir, lowa, Clinton and Pomona Lakes, Kansas, and Harlan County Reservoir, Nebraska, May Through August 1993 


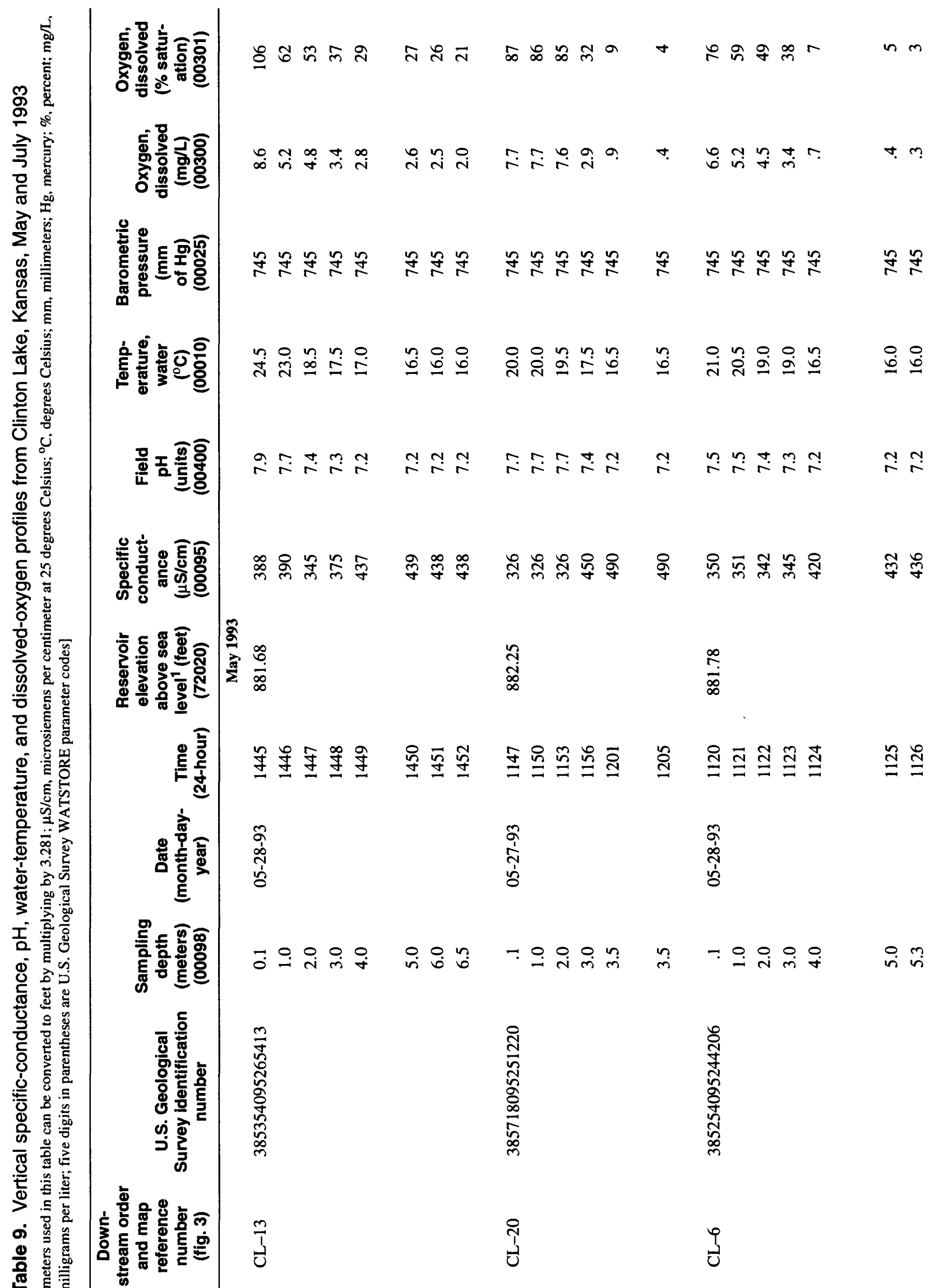




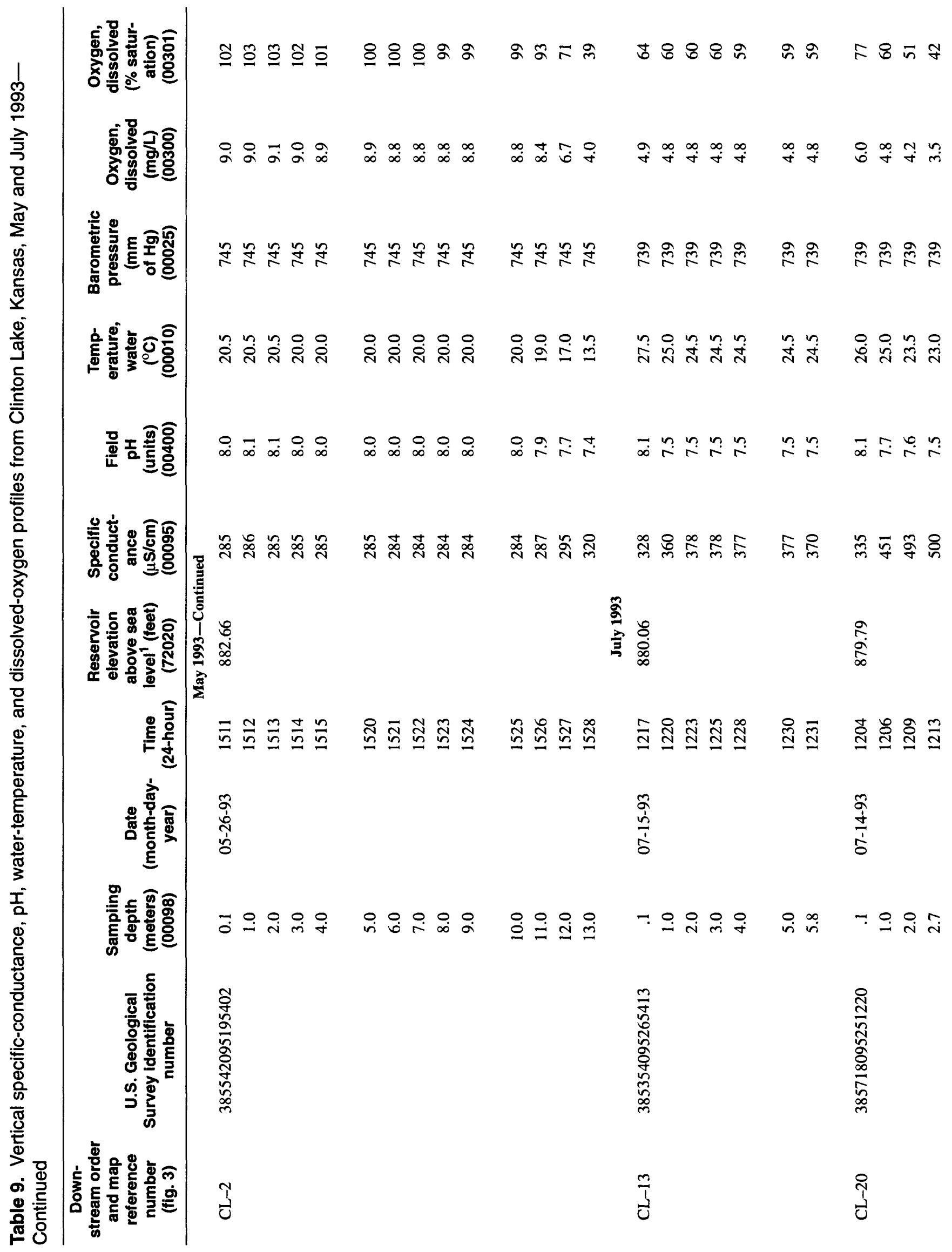




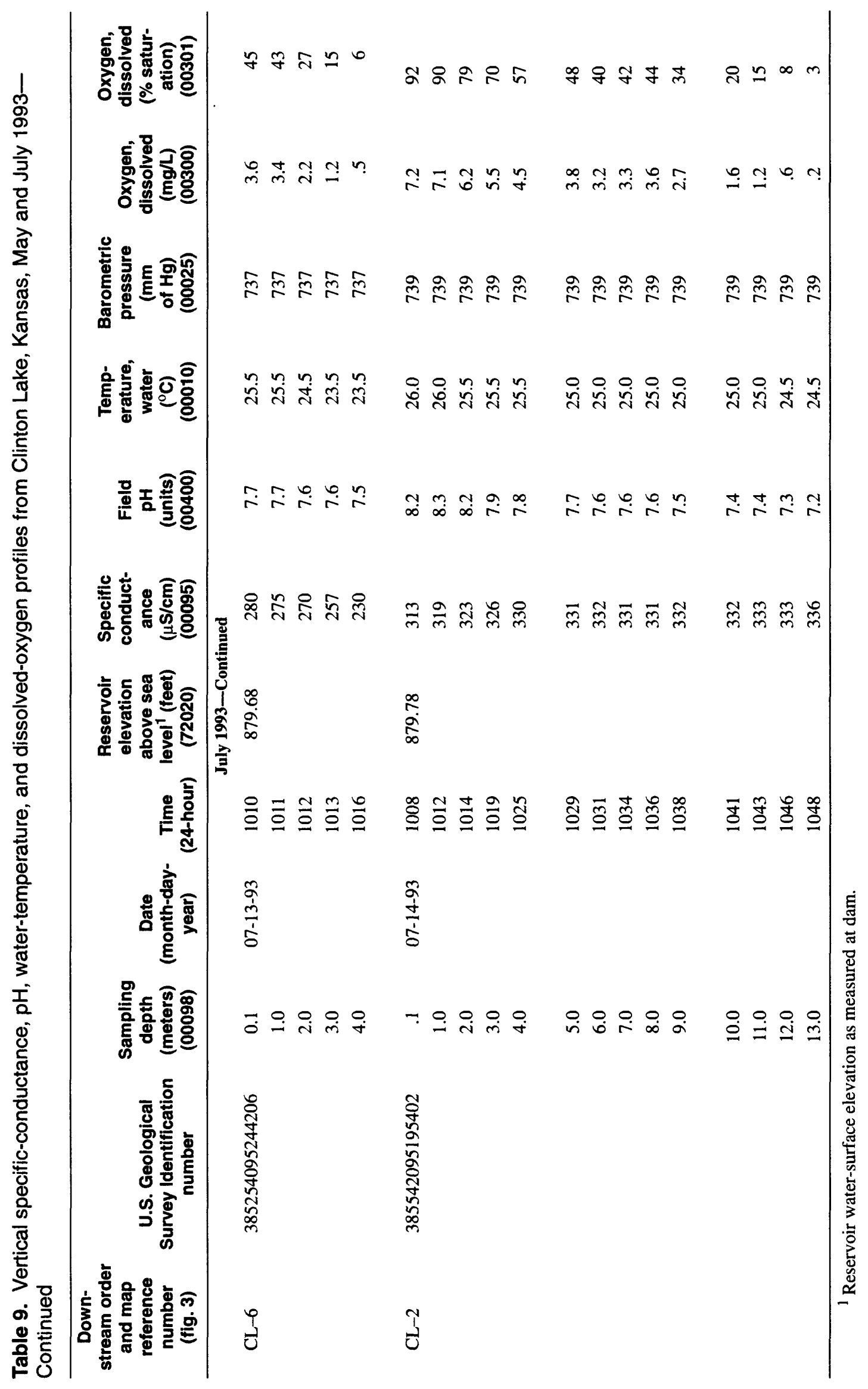




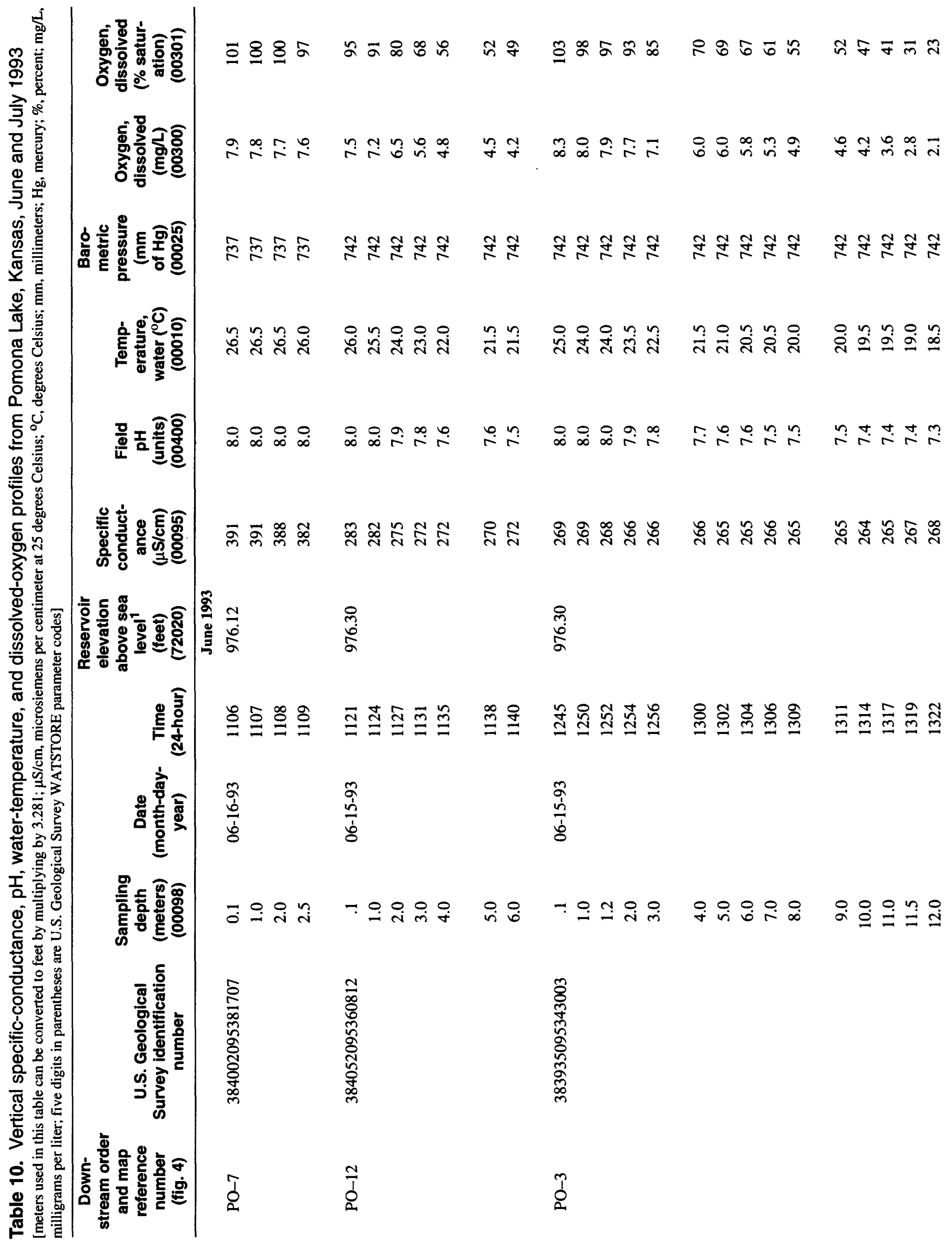

68 Water-Quality Conditlons of Inflow, Outflow, and Impounded Water at Rathbun Reservoir, lowa, Clinton and Pomona Lakes, Kansas, and Harlan County Reservoir, Nebraska, May Through August 1993 


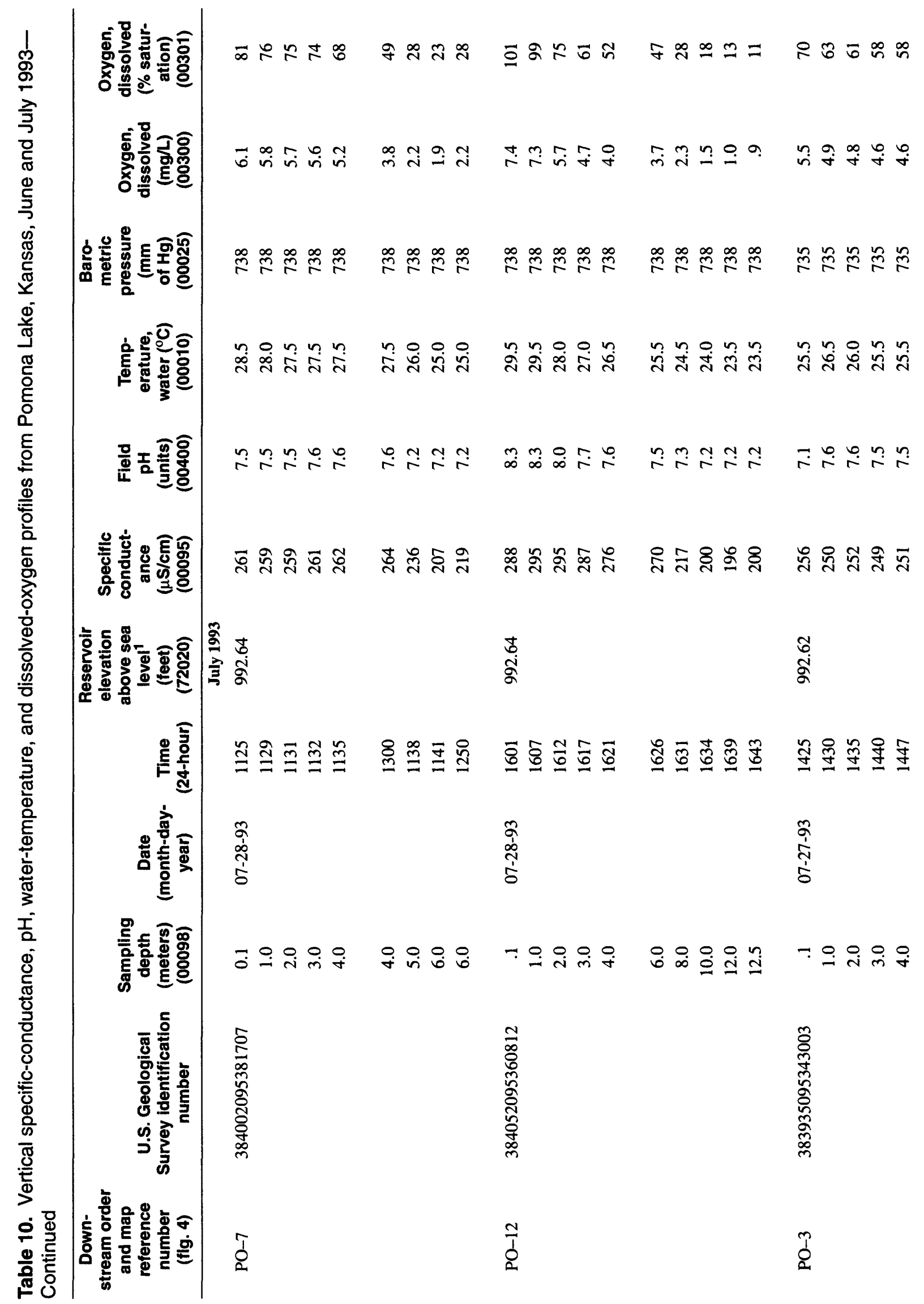




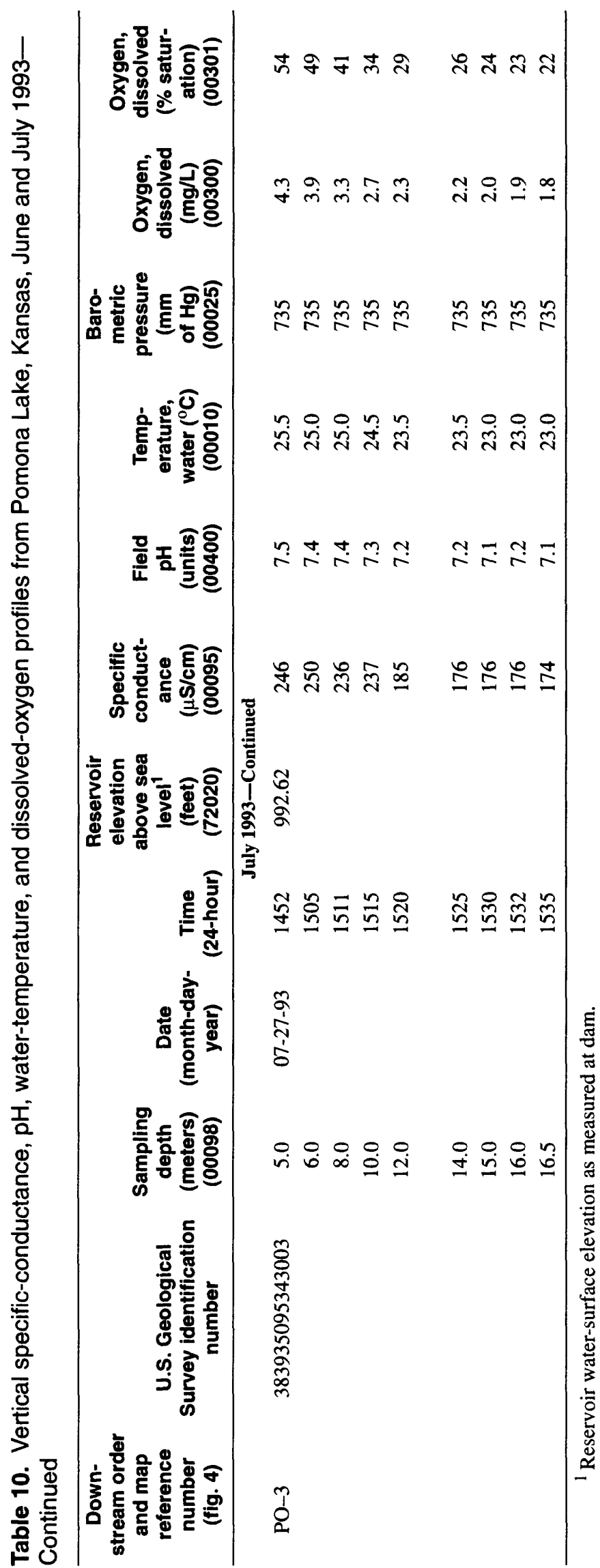

70 Water-Quality Conditions of Inflow, Outflow, and Impounded Water at Rathbun Reservoir, lowa, Clinton and Pomona Lakes, Kansas, and Harlan County Reservoir, Nebraska, May Through August 1993 


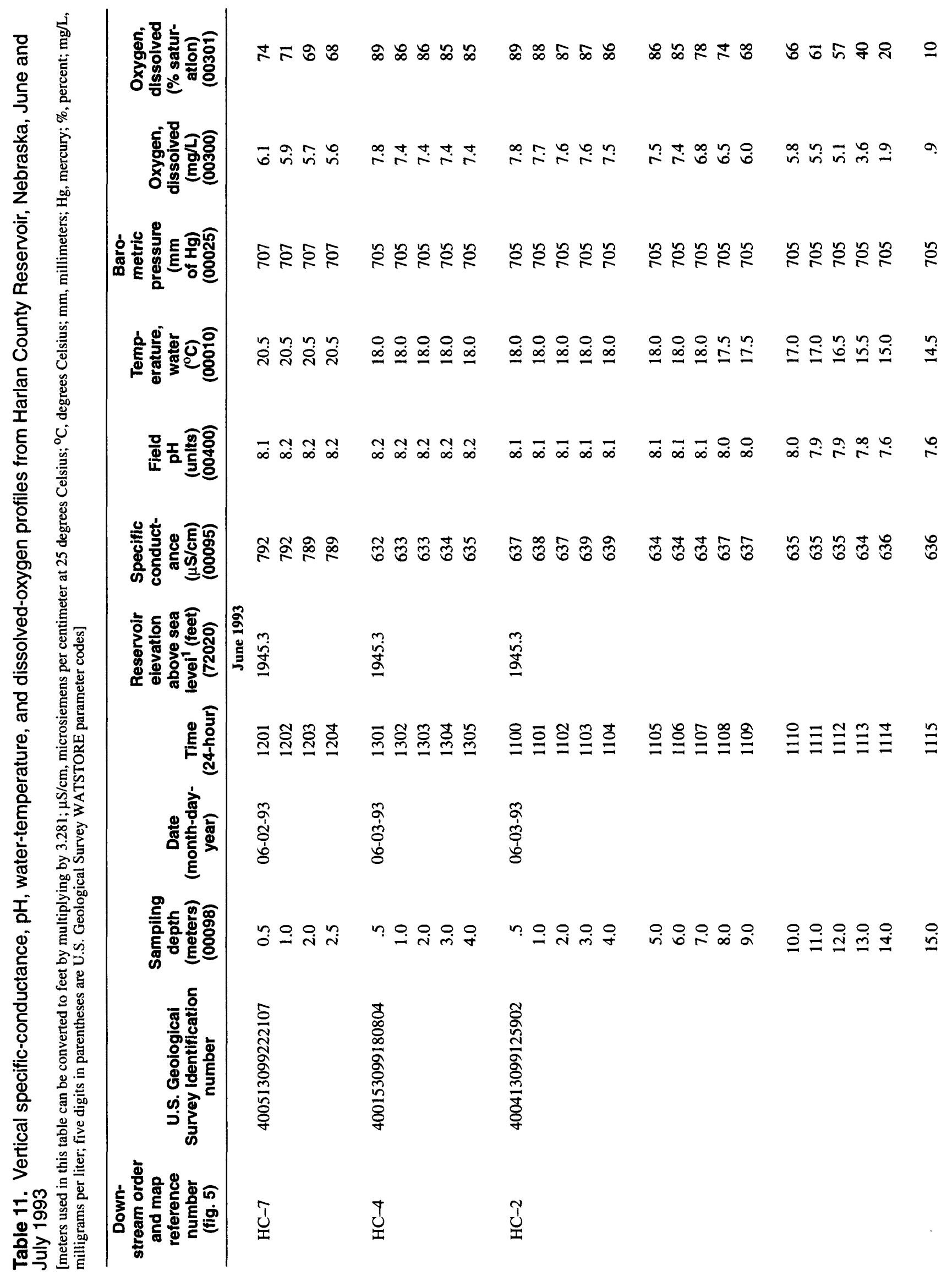




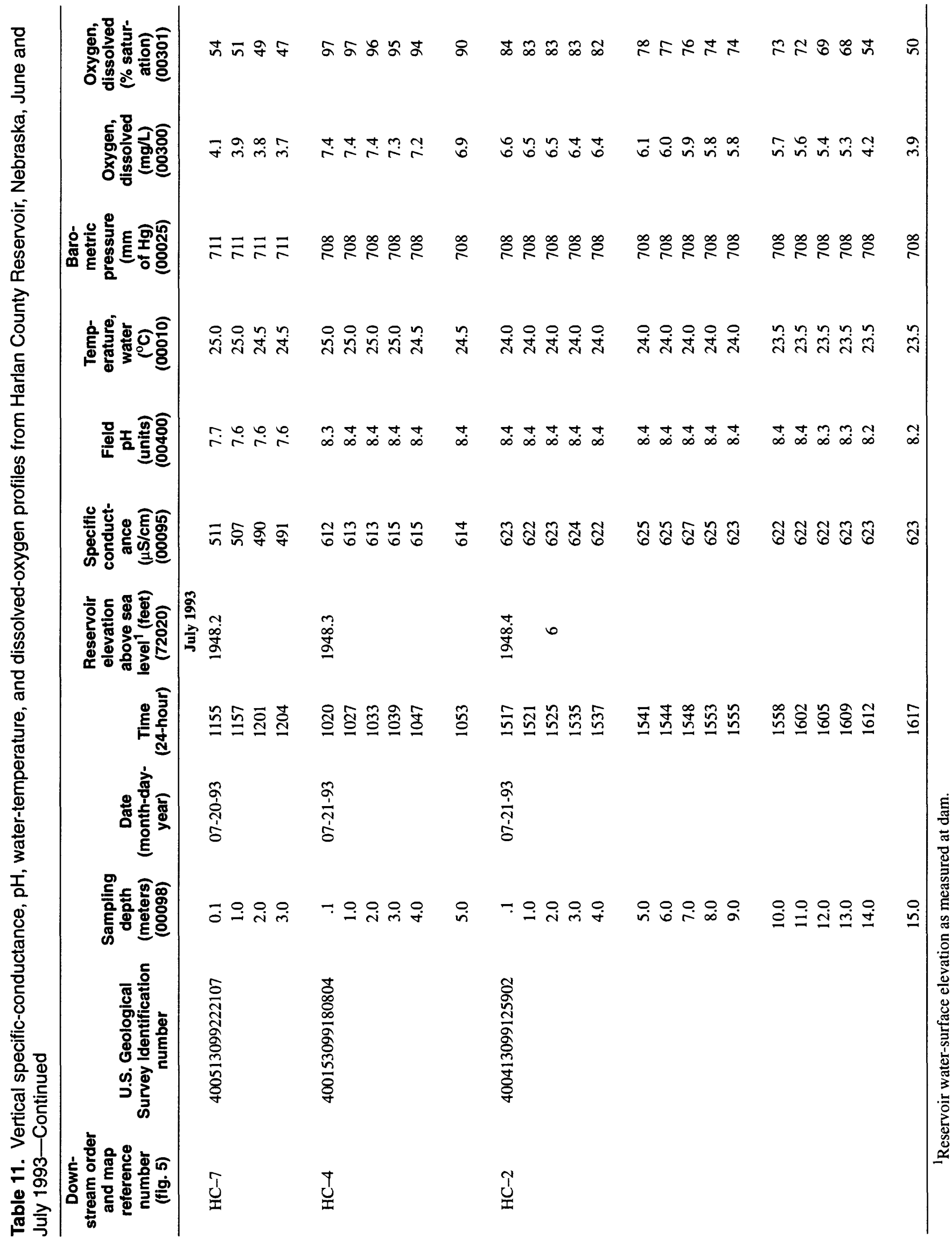

72 Water-Quality Conditions of Inflow, Outflow, and Impounded Water at Rathbun Reservoir, lowa, Clinton and Pomona Lakes, Kansas, and Harlan County Reservoir, Nebraska, May Through August 1993 